\title{
Uma exposição para o IV Centenário de São Paulo: um historiador português narra a "história bandeirante" 1
}

An exhibition for the $4^{\text {th }}$ centenary of São Paulo: a Portuguese historian tells the "Bandeirante history"

\section{DAVID WILLIAM APARECIDO RIBEIRO²}

Universidade de São Paulo / São Paulo, SP, Brasil
RESUMO: Jaime Cortesão, intelectual português, viveu no Brasil entre 1940 e 1957 após ser banido de seu país pelo regime salazarista. Durante este período, instalado no Rio de Janeiro, foi presença assídua na imprensa carioca e paulistana, além de trabalhar na Biblioteca Nacional e no Instituto Rio Branco, onde teve contato privilegiado com a documentação que the possibilitou escrever uma história da "formação territorial do Brasil". Convidado para participar das comemorações do quarto centenário da fundação de São Paulo, Cortesão idealizou a exposição montada em um dos pavilhões do recém-inaugurado Parque Ibirapuera. Reunindo obras de arte e objetos emprestados por particulares e instituições nacionais e estrangeiras, além de murais, mapas e esculturas feitas para a ocasião por artistas convidados, a mostra teve grande influência na museologia paulista e na própria trajetória posterior de Cortesão. Neste artigo discutiremos sobre essa mostra por meio de uma análise do catálogo manuscrito da Exposição de história de São Paulo no quadro da história do Brasil, guardado no arquivo de Jaime Cortesão na Biblioteca Nacional de Portugal.

\footnotetext{
1. Este texto é uma versão reformulada de parte da pesquisa desenvolvida no mestrado junto ao Programa de Pós-Graduação em História Social da Faculdade de Filosofia, Letras e Ciências Humanas da Universidade de São Paulo (FFLCH-USP), orientada pela professora Maria Cristina Cortez Wissenbach. A pesquisa na Biblioteca Nacional de Portugal contou com o financiamento da Cátedra Jaime Cortesão/ Instituto Camões e a supervisão da professora Patricia Santos Hansen.

2. Doutorando em História Social na FFLCH-USP. E-mail:<dwribeiro@gmail. com>
} 
ABSTRACT: Jaime Cortesão, Portuguese intellectual, lived in Brazil between 1940 and 1957 after being banished from his country by the Salazar regime. During this period, he was a frequent presence in the Rio de Janeiro and São Paulo press, as well as working at the National Library and the Rio Branco Institute, where he had privileged contact with the documentation that enabled him to write a history of the "Brazilian territorial formation". Invited to participate in the celebrations of the 4th centenary of the founding of the city of São Paulo, Cortesão idealized the exhibition mounted in one of the pavilions of the recently inaugurated lbirapuera Park. Bringing together works of art and objects lent by individuals and institutions from different countries, as well as murals, maps, sculptures made for the occasion by invited artists, the exhibition had a great influence on the museology of São Paulo and on the later trajectory of Cortesão. In this article, we will discuss this exhibition through an analysis of the manuscript catalog of the Exposição da história de São Paulo no quadro da história do Brasil, stored in the Jaime Cortesão's archive at the National Library of Portugal.

KEYWORDS: São Paulo (city). Museology. Intellectual history. Historiography.

\section{JAIME CORTESÃO, O INTELECTUAL EXILADO NO BRASIL}

Jaime Cortesão nasceu nas cercanias de Coimbra em 1884, seguindo seus estudos em Direito e Medicina. Militante republicano, aproximou-se de correntes anarquistas, socialistas e de artistas de diversos ofícios, sendo ele próprio desenhista, dramaturgo e poeta. Após o advento da República Portuguesa, proclamada em outubro de 1910, Cortesão e seu grupo fundaram na cidade do Porto um movimento chamado Renascença Portuguesa, cujo objetivo era orientar as forças da nova república, revivendo valores e sentimentos do Portugal de outrora. ${ }^{3}$ Com um amplo programa de ação, o grupo empreendeu diversas iniciativas sobretudo na área da educação e da circulação de ideais, sendo interrompido pela eclosão da Primeira Guerra Mundial (1914-1918), que acrescentaria novos ingredientes à já conturbada nação, assolada por sucessivas crises políticas, econômicas e identitárias. ${ }^{4}$ 
Como reconhecimento por suas ações nas trincheiras e também pelo atendimento médico aos combatentes, Cortesão foi agraciado pelo governo português com a direção da Biblioteca Nacional em 1919, de onde deu novo ânimo a seus projetos. Lá formou o chamado grupo da Biblioteca, que anos depois ganharia o nome de Seara Nova, cuja revista congregaria muitos intelectuais locais em torno de um projeto de país. Os intentos do grupo, entretanto, foram interrompidos, desta vez por um golpe de Estado que daria início a quase cinco séculos de um governo ditatorial centrado na figura de Antonio de Oliveira Salazar. Tomando parte em uma ação de contra-ataque, Cortesão e alguns dos seus foram demitidos da Biblioteca e tomaram rumos distintos.

$\bigcirc$ ano de 1928 marcou o início do que seria um longo desterro, a princípio por vontade própria, diante das circunstâncias nada favoráveis à sua atividade intelectual. Na Espanha - onde também testemunharia um golpe - e depois na França, Jaime Cortesão deu continuidade a sua ação política, vinculando-se a portugueses no exterior e a outros que permaneciam em sua terra. Conforme registrou, o período foi fundamental para que passasse a se dedicar ao ofício de historiador, entrando em contato com os arquivos franceses, ingleses, belgas, entre outros, nos quais buscou fontes para a escrita da história de Portugal. Foi durante o período do exílio francês que Cortesão começou a trabalhar com as fontes cartográficas, que se tornaria a sua área de maior produção e interesse nas décadas seguintes. ${ }^{5}$

Entretanto, um novo golpe muda o caminho de Cortesão: a invasão das tropas nazistas sobre Paris, em 1940, obrigaram um grande contingente - entre eles, diversos outros refugiados que haviam escolhido aquele país naqueles tempos de regimes totalitários e autoritários - a abandonar a capital francesa, migrando às pressas para outros lugares. Apesar da anistia concedida pelo governo português aos lusitanos que se encontravam fora do país por razões políticas, Cortesão foi preso ao cruzar a fronteira quando voltava para Portugal e recebeu um ultimato: estava banido e deveria deixar seu país antes do fim daquele ano. ${ }^{\circ}$

A bordo do S/S Angola, Jaime Cortesão aportou no Rio de Janeiro, então capital do Brasil, em dezembro de 1940. Sua chegada havia sido anunciada pela imprensa carioca e em pouco tempo já proferia as suas primeiras conferências, tanto na capital federal quanto em São Paulo. Esta recepção demonstra os laços existentes entre intelectuais e associações brasileiras e portuguesas e uma circulação entre os dois lados do Atlântico, o que em muito contribuiu para que Cortesão se integrasse rapidamente ao circuito brasileiro.7 Cabe lembrar que em sua primeira apresentação pública em São Paulo, no auditório d'A Gazeta, o intelectual português registrou perante a assistência seu olhar sobre a fundação e
5. Cf. Jaime Cortesão (Biblioteca Nacional de Portugal (BNP)/Arquivo de Cultura Portuguesa Contemporânea (ACPC), E25/20, 34, 81, 1929; s/d).

6. Santos (1993, p. 183185).

7. Cortesão (1987, p. 77, 81) e Ribeiro (1952, p. 187). 
8. Cf. Jaime Cortesão (BNP/ ACPC, E25/40, 1940).

9. Sobre o "fator geográfico" na escrita histórica de Jaime Cortesão, cf. Macedo (1984).

10. Conjunto de documentos adquiridos pelo Império do Brasil sob guarda da Biblioteca Nacional referentes à região da bacia do Prata. A coleção foi organizada por Cortesão por sub-regiões e sob o título "Jesuítas e Bandeirantes", indicando os conflitos entre espanhóis e portugueses pela soberania na região ocupada por populações sobretudo Guarani.

11. O Estado de S. Paulo, São Paulo, 20 mar. 1953, p. 10. estabelecimento da vila de Piratininga no planalto, ressaltando a função paulista no quadro da colonização portuguesa do Brasil e na penetração para o interior do continente. ${ }^{8}$ Ao longo de sua experiência brasileira, Cortesão se aprofundaria nesse estudo, inserido em uma interpretação da história nacional em que o "fator geográfico" se destaca. ${ }^{9}$

Diferentemente de outros intelectuais portugueses então residentes no Brasil, Jaime Cortesão passou a trabalhar, de forma relativamente rápida, em espaços aparentemente exclusivos aos nacionais, em tempos de nacionalismo exacerbado (ainda que coubesse aos portugueses um lugar distinto daquele destinado aos outros estrangeiros). É relevante em sua trajetória no hemisfério sul o trabalho que desempenhou na Biblioteca Nacional e no Ministério das Relações Exteriores, ambos no centro do poder do Estado Novo de Getúlio Vargas, e lidando com temas quentes do debate brasileiro de então. Na Biblioteca Nacional, à qual esteve vinculado durante mais de uma década, trabalhou com documentos inéditos sobre a presença jesuítica e as empreitadas de bandeirantes na bacia do Prata - os Manuscritos da Coleção De Angelis - volumes que coligiu e para os quais escreveu introduções e comentários. ${ }^{10}$ Esta documentação fundamentou os cursos de formação de diplomatas que ofereceu no Itamaraty, acompanhadas de outras fontes da mapoteca deste Ministério, além de terem servido a outros estudos do autor. Ao debruçar-se sobre essas fontes e produzir textos como Alexandre de Gusmão e o Tratado de Madrid sob o selo de editoras oficiais, tomando parte de temas bastante caros durante uma época em que se discutia a integração do território nacional e se buscavam as bases da nacionalidade no interior do país, Cortesão era posto em destaque, sendo requisitado em diversos locais e também recebendo críticas por ser um estrangeiro a desfrutar do acesso a documentos ainda inéditos e de seu grande reconhecimento por parte do Estado.

Foi provavelmente em razão dessa visibilidade que a Comissão do IV Centenário de São Paulo, por meio de seu presidente Francisco Matarazzo Sobrinho, solicitou a Cortesão, que partia em viagem à Europa a serviço do Itamaraty, a reunião de documentos sobre a história paulista para as comemorações centenárias. Doze anos depois, Cortesão voltava a Lisboa, merecendo um número especial na revista Seara Nova. Ao voltar para o Brasil com diversos documentos cartográficos, foi convidado para transformar o que seria apenas uma mostra de mapas paulistas antigos em uma grande mostra de história. " Com a relação intermediada por Paulo Duarte, intelectual e ex-redator-chefe d'O Estado de S. Paulo, e por Sarmento Pimentel, seareiro estabelecido em São Paulo, Cortesão se 
assegurou de ter plenas condições para organizar a mostra de acordo com seus critérios antes de aceitar o convite. ${ }^{12}$

plano da exposição, segundo Cortesão em entrevista ao Estado de S. Paulo, pertencia "em germe" a Matarazzo. Na mesma entrevista, o historiador comentou sobre sua hesitação em aceitar a direção da exposição, ciente da "grande, mas pesada honra decorrente de semelhante encargo". "13 Sarmento Pimentel chamou o plano de Cortesão de "novo padrão lusíada nas terras americanas" e ainda comentou sobre a disposição da colônia portuguesa organizada, que se mobilizaria em todo o Brasil para financiar a "obra magnífica" do compatriota e outras homenagens à cidade. ${ }^{14}$

Dessa forma, a Exposição de história de São Paulo no quadro da história do Brasil se inseriu em outro quadro, o da "missão portuguesa" que, segundo Antonio Candido, marcou profundamente a cultura brasileira na metade do século passado, ainda que não tenha sido um movimento organizado e temporalmente localizado como outras missões, como a dos franceses quando da fundação da Universidade de São Paulo. ${ }^{15}$ Do mesmo modo, a mostra representou um importante elemento do programa que orientou as atividades de Cortesão, desde sua saída de Portugal, em relação à história portuguesa e a sua função de restituir a autoestima ao país. ${ }^{16}$

Além deste breve panorama sobre os trânsitos e sociabilidades intelectuais de Jaime Cortesão, cujas relações e condições marcaram sobremaneira suas abordagens da história, este texto apresenta uma análise sobre a concepção e exibição da mostra histórica do IV Centenário de São Paulo, com base na documentação reunida no Espólio Jaime Cortesão do Arquivo de Cultura Portuguesa Contemporânea da Biblioteca Nacional de Portugal. $\bigcirc$ referido Espólio se divide em duas grandes partes, sendo que a primeira, inventariada, reúne correspondências, manuscritos de conferências e de livros, recortes de imprensa, documentos referentes aos cursos oferecidos no Itamarały, fotografias da exposição paulistana e da Exposição do Mundo Português de 1940, ${ }^{17}$ entre outros. A segunda parte, parcialmente organizada e parcamente descrita, reúne sobretudo manuscritos e uma grande quantidade de fontes referentes à exposição, incluindo os manuscritos do que seria o catálogo da mostra, jamais publicado. ${ }^{18}$ É sobre essa documentação de pouco mais de trezentas páginas datilografadas que nos dedicaremos, identificando o que os visitantes encontraram no Palácio de Exposições, hoje Pavilhão Governador Lucas Nogueira Garcez, ou Oca entre 1954 e 1955.
12. Cf. João Sarmento Pimentel (BNP/ACPC, E25/758, 22 mar. 1953)

13. O Estado de S. Paulo, São Paulo, 8 jul. 1954, p. 11.

14. Cf. João Sarmento Pimentel (BNP/ACPC, E25/760, 29 jun. 1953).

15. Prefácio de Antonio Candido de Mello e Souza, em Lemos e Leite (2003, p. 15).

16. Cf. Cortesão (1991).

17. Cf. Thomaz (2002).

18. Ainda que o Arquivo Nacional Brasileiro (1954) tenha publicado um catálogo destacando suas contribuições para a exposição paulistana, o catálogo manuscrito pelo organizador da mostra ficou inédito. 
19. Lofego (2004, p. 29, 32).

20. Martins (2013, p. 17, 25, 79, 131-171)

21. Barbuy (2006) utiliza a ideia de "cidade em exposição" para compreender a dinâmica da transformação da cidade de São Paulo da Belle Époque, em que a profusão de vitrines introduzia a linguagem das exposições para a vida comercial urbana. As modificações de grande porte então levadas a cabo, levantando arranhacéus e abrindo vias ao automóvel, expunham um paradigma de cidade moderna, desenhado a partir dos anseios das elites locais e nacionais na metade do século passado e destinado a se irradiar pelo país.

22. Marins (1999).

\section{A CIDADE SE PREPARA PARA A GRANDE FESTA}

As comemorações da passagem do quarto centenário da fundação da cidade de São Paulo, planejadas em torno do 25 de janeiro de 1954, foram interpretadas pelo historiador Silvio Luiz Lofego como uma complexa articulação entre o passado e o futuro da metrópole, na qual a projeção de futuro exigia uma narrativa do passado "à altura das aspirações do presente". Para além dos objetivos locais, o autor destaca "o papel da festa comemorativa para o sucesso da propaganda paulista, que divulgou São Paulo como modelo para o Brasil", fazendo frente à então capital do país, o Rio de Janeiro, centro de todas as atenções. ${ }^{19}$ A responsabilidade pela organização geral dos festejos ficou a cargo de uma autarquia criada pelo poder público municipal, a Comissão do IV Centenário da Cidade de São Paulo (CIVCCSP), dirigida pelo industrial e mecenas ítalo-brasileiro Francisco Matarazzo Sobrinho e posteriormente pelo escritor Guilherme de Almeida.

Naquele contexto, as transformações do espaço da cidade de São Paulo também agiram sobre as percepções da população em relação à vida urbana, concorrendo para a fixação do "bombardeio ufanista", como diz Lofego, em torno das comemorações. As fotografias selecionadas por German Lorca - um dos responsáveis por um dos registros mais marcantes das comemorações centenárias - permitem não somente identificar alguns dos elementos da identidade visual da cidade, como o edifício Altino Arantes, inaugurado em 1947, como uma profusão de canteiros de obras, como as do Parque lbirapuera e da Catedral da Sé, ambas construções do contexto das comemorações de 1954. ${ }^{20}$ São Paulo, construindo novamente suas representações como havia feito nos tempos da Belle Époque, era um paradigma de cidade em exposição: ${ }^{21}$ Os signos e sentidos da modernidade que já tinham sido à europeia agora se miravam no ideal representado pelos Estados Unidos.

Entre aspirações de futuro e modificações profundas do espaço urbano não haverá, no contexto das comemorações do quarto centenário, lugar mais significativo do que o Parque Ibirapuera. Para compreender os sentidos encerrados na construção do parque e dos monumentos em seu redor, sigo a intepretação de Paulo César Garcez Marins, ${ }^{22}$ partindo da análise instigante de três dos principais "empreendimentos artísticos de caráter monumental" construídos até a data do quarto centenário de São Paulo: o Monumento às Bandeiras, o Monumento e Mausoléu ao Soldado Constitucionalista de 1932 e os pavilhões para as exposições comemorativas do $400^{\circ}$ aniversário da cidade. De acordo com Marins, 
[c]oncentraram-se ali os símbolos de caráter comunitário, propostos ou subsidiados pelo poder público, todos eles diretamente ligados à representação da identidade paulista, do ser paulista, atos afirmativos necessariamente impactantes em anos de grandes transformações demográficas, sociais e culturais não só para a cidade, como para seu estado e para o próprio país. ${ }^{23}$

Ainda segundo o autor, as obras, concebidas em décadas distintas e erigidas entre 1953 e 1955, permitem a percepção de "mutações arquiteturais e escultóricas" que expressam uma múltipla consciência, assim como o "caráter ideológico de círculos culturais articulados ao poder público no esforço por dotar a capital de símbolos que evidenciassem, ou unissem os muitos e múltiplos paulistas". Guiando-se pelo mito bandeirante, "a mais eficiente e duradoura construção simbólica operada no estado durante a primeira metade do século XX", Marins constrói uma interpretação sobre a plástica adotada nas três realizações destacadas, analisando os meandros da "afirmação, transformação e diluição dos nexos entre o ser paulista, seu passado e a formulação de seu futuro". ${ }^{24}$

Para Marins, o Parque Ibirapuera, "de linhas modernas e modernistas tornava-se o novo marco zero da capital, refundando-a". ${ }^{25}$ Igualmente trabalhado por Marins e Lofego, ${ }^{26}$ os sentidos da comemoração estavam sintetizados naquele que foi escolhido como o emblema, o selo oficial do grande evento: a aspiral. Batizado por Matarazzo com um nome que remete ao futuro, o desenho helicoidal de Zenon Lotufo e equipe "funcionava como ícone de um monumento a ser erguido durante o quarto centenário: a memória da grandiosidade de São Paulo". Projetavase a cidade em crescimento, incontestavelmente registrada ao longo do conjunto de comemorações ${ }^{27}$ Além disso, para Matarazzo o Ibirapuera tinha como função a perpetuação da grandeza daquela data. ${ }^{28}$

No conjunto arquitetônico desenhado por Niemeyer e equipe para que o Parque Ibirapuera recebesse as exposições em comemoração ao quarto centenário paulistano, uma edificação junto à entrada principal se destacava: o Palácio de Exposições. Durante décadas, o edifício abrigou o Museu do Folclore e o Museu da Aeronáutica, que desocuparam o local na década de 1990, quando o pavilhão foi preparado para receber parte substancial da Mostra do Redescobrimento, em comemoração aos quinhentos anos da chegada da armada de Cabral. Hoje, a Oca ainda é um dos principais espaços de exposições da cidade e está sob administração da Secretaria Municipal de Cultura desde 2010, integrando o Museu da Cidade de São Paulo, um conjunto de espaços museológicos articulados.

Foi nesse espaço de cerca de sete mil metros quadrados dispostos em dois pavimentos, cuja visualidade externa alude a uma moradia indígena, que em 13 de setembro de 1954 foi solenemente aberta para convidados a Exposição de
23. Marins (1999, p. 9).

24. Marins (1999, p. 9-10, grifos do autor).

25. Marins (1999, p. 33).

26. Lofego (2004) e Marins (1999).

27. Lofego (2004, p. 175).

28. Lofego (2004, p. 76). 
29. A equipe de colaboradores contou ainda com Agostinho da Silva, Antonio Pedro Rodrigues e Armando Cortesão, portugueses, e Darcy Ribeiro, Francisco Rodrigues Leite, Gastão Cesar Bierrenbach de Lima, João Cruz Costa, José Wasth Rodrigues, Luís Saia, Miranda Maria Esmeralda Martinelli, Salomão de Vasconcelos e Yan de Almeida Prado. Cf. Jaime Cortesão (BNP/ACPC, E25/ Cx. 64, Pasta 20).

30. Sobre as redes intelectuais paulistanas de então e suas dinâmicas, cf. Pontes (1998).

31. Silva (2014, p. 80-81).

32. Cf. Mário Neme (BNP/ ACPC, E25/Cx. 64, 4 set. 1953).

33. Cf. Jaime Cortesão (BNP/ACPC, E25/Cx. 64, Pasta 20, 21 set. 1953).

34. Cf. Jaime Cortesão (BNP/ACPC, E25/Cx. 64, Pasta 20, 5 dez. 1953). história de São Paulo no quadro da história do Brasil, sob a curadoria do professor Jaime Cortesão, com o auxílio direto de Mário Neme, Ernani Silva Bruno e Hélio Damante. $^{29}$

\section{A PREPARAÇÃO DA EXPOSIÇÃO}

Cortesão esteve na Europa mais uma vez entre os últimos meses de 1953 e os primeiros de 1954, como organizador da Exposição de São Paulo. Durante a viagem, seu correspondente mais assíduo do Brasil foi Mário Neme, um intelectual piracicabano do círculo das revistas Clima e Planalto, ${ }^{30}$ designado para participar da comissão organizadora dos festejos paulistanos por ser servidor público municipal, assim um elo direto entre comissão e administração pública. Atuando como assistente, Neme "passou a pensar e organizar juntamente com Cortesão os trabalhos da exposição", dialogando diretamente com Matarazzo, Hélio Damante e Ernani Silva Bruno. ${ }^{31}$

Nos preparativos da ida de Cortesão para a Europa, Mário Neme the escreveu mediando um encontro com Matarazzo e comunicando o contato estabelecido com Alice Canabrava e Ernani Silva Bruno, historiadores que deveriam auxiliá-lo nos trabalhos. Agostinho da Silva, português e professor em Pernambuco, deveria entrar em contato em breve. ${ }^{32}$ Em resposta, já de Lisboa, Cortesão relatou seus primeiros dias na capital portuguesa, recomendando a Neme que se ocupasse das três últimas seções da exposição, dividida em nove, junto de seus responsáveis. $\bigcirc$ historiador se disse surpreso com a acolhida que the deu o Governo Português quando de sua chegada, comunicando que a presidência do Arquivo Histórico Ultramarino the havia dado livre acesso aos verbetes sobre a história de São Paulo que estavam sendo preparados pela instituição. A mesma disposição disse ter encontrado do Arquivo Nacional da Torre do Tombo. Além disso, Cortesão comentou sobre o início das tratativas de encomendas artísticas e cedência de originais, assuntos sobre os quais escreveria circunstanciadamente a Matarazzo. ${ }^{33}$

Em uma correspondência de Cortesão enviada a Matarazzo, o historiador mencionou seu contato com "artistas portugueses especializados na organização de exposições para dar expressão original à parte mais estritamente portuguesa da Exposição Histórica de S. Paulo", constituindo para tanto um comitê formado "pelo melhor grupo de artistas daquela especialidade": Bernardo Marques e Manuel Lapa, sob a presidência do escultor Diogo de Macedo, diretor do Museu de Arte Contemporânea. ${ }^{34} \bigcirc$ trabalho realizado pelos artistas já estava bastante 
adiantado quando da volta de Cortesão dos outros países que visitou. Tudo o que fosse produzido seria ainda enviado a um decorador português residente no Rio de Janeiro, Artur Jorge, que por sua vez iria a São Paulo encontrar-se com o arquiteto Jacob Rusti, com quem se entenderia a respeito da execução do trabalho da exposição, podendo ainda estender seus serviços a outras seções além das seis primeiras que estavam sob direta responsabilidade de Cortesão.

Na sequência, Cortesão descreveu o que havia feito na França, Holanda, Bélgica e Itália. Na capital francesa, por intermédio da embaixada brasileira, visitou arquivos e museus e apresentou uma lista de objetos que solicitou emprestados. De um alto funcionário do Ministério da Cultura francês, Cortesão disse ter sentido uma "discreta boa vontade" em atender aos pedidos, menos os da longa lista de mapas históricos da Biblioteca Nacional, como o de Lopo Homem, de 1519.35 Extraoficialmente, o historiador se encontrou com um colecionador e antiquário de suas relações e este se prontificou a emprestar pinturas de Post, Debret, J. A. Taunay, cenas a partir de Rugendas etc. Nos museus holandeses de Haia e Amsterdã, Cortesão conseguiu reproduções de retratos e de quadros, dentre os quais obras de Frans Post. ${ }^{36}$

Nota-se na correspondência o empenho do governo salazarista em participar com relevo das comemorações, o que seguramente não é vazio de significado. A grandiosidade do evento era uma oportunidade sem tamanho para divulgar as raízes lusas da capital paulista e do Brasil, ainda mais tendo um português, mesmo que oponente no campo político, à frente da exposição histórica. Aquele governo, como apontou Omar Thomaz, era exemplar em relação ao uso da linguagem das exposições para fazer propaganda do regime e da "raça" portuguesa. ${ }^{37} \bigcirc$ empenho não quer dizer, entretanto, que Cortesão passava a ser bem visto pelo Governo de Portugal. A violação de correspondências com o amigo David Ferreira indica que os olhos da polícia política salazarista estavam sobre o historiador. Em uma missiva de março de 1955, o remetente solicita que Cortesão não torne a pôr seu nome, nem utilize nada que aluda à CIVCCSP, além de tomar outras medidas de segurança. ${ }^{38}$

Além de Neme e Ferreira, que cuidou da parte financeira, outro auxiliar de Cortesão foi George Agostinho da Silva, este dos círculos intelectual e familiar - o seareiro também radicado no Brasil era casado com a filha de Jaime, Judith Cortesão -, atuou diretamente na organização da exposição. De acordo com o trabalho de Gilson Brandão de Oliveira Júnior, o pensamento de Silva, fortemente marcado por Jaime Cortesão, Gilberto Freyre e Antonio Sérgio, teve grande peso em suas concepções quando da criação do Centro de Estudos Afro-Orientais (CEAO), na Bahia, e na área das relações internacionais. Conforme o autor, Silva
35. Cf. Jaime Cortesão (BNP/ACPC, E25/Cx. 64, Pasta 20, 5 dez. 1953).

36. Cf. Jaime Cortesão (BNP/ACPC, E25/Cx. 64, Pasta 20, 5 dez. 1953).

37. Cf. Thomaz (2002).

38. Cf. David Ferreira (BNP/ACPC, E25/469, 13 mar. 1955) 
39. Oliveira Júnior (2010, p. 110).

40. Cf. Agostinho da Silva (BNP/ACPC, E25/1022, 1025, 4 maio/18 ago. 1953).

41. O Estado de S. Paulo, São Paulo, $1^{\circ}$ out. 1954, p. 15.

42. O Estado de S. Paulo, São Paulo, 14 nov. 1954, p. 8. tinha vivido experiências muito semelhantes às de Jaime Cortesão na Seara Nova, na França, na Espanha e no Brasil. ${ }^{39}$ Trabalhando de longe e de perto das atividades de Cortesão, Agostinho da Silva e Judith Cortesão colaboraram na edição de Alexandre de Gusmão e o Tratado de Madrid. O casal morava em João Pessoa, onde Silva era professor da Universidade da Paraíba, da qual se licenciou durante um curto período para poder acompanhar a organização da exposição paulistana. ${ }^{40}$ Do que consta em nota n'O Estado de S. Paulo, Agostinho da Silva era um dos encarregados da exposição que ficavam no Ibirapuera e recebiam os telefonemas de quem quisesse se informar sobre como agendar visitas especiais, como para grupos escolares. ${ }^{41}$

○ fato de Cortesão estar trabalhando com a documentação cartográfica desde os tempos de sua residência em Paris, perspectiva que se tornaria ainda mais relevante após seu ingresso como consultor e depois como professor no Ministério das Relações Exteriores, por si só seriam suficientes para compreender a cartografia histórica como linha mestra da Exposição de História de São Paulo. Além disso, a relação com a cartografia também estava presente no ambiente familiar, pois o historiador tinha como irmão e grande interlocutor e colaborador Armando Cortesão, funcionário da Unesco que também trabalhava com fontes cartográficas. Junto de Avelino Teixeira da Mota, Armando Cortesão trabalhou na recolha e organização de mapas, planos e outras fontes afins sobre Portugal, Brasil e as então colônias portuguesas, publicando posteriormente esse material como parte das comemorações ao quinto centenário da morte do Infante D. Henrique. O irmão também colaborou para a execução da exposição, assim como tinha auxiliado o autor quando da produção da obra sobre Alexandre de Gusmão.

Compondo o cenário do novíssimo parque, compartilhava o espaço com a Exposição de história a I Feira Internacional de São Paulo, que anunciava a capital paulista como "a Meca do mundo" naquele 1954. Comércio, indústria e agricultura brasileiros desfrutariam de um momento sem igual para "o desenvolvimento de suas atividades", junto das "mais modernas produções" de "poderosas firmas de todos os continentes". Como o nome sugere e o texto publicitário diz, a feira seria um grande mercado da Indústria, do Comércio, da Agricultura, das Nações e dos Estados instalado nos pavilhões, se apresentando como uma grande oportunidade para o desenvolvimento econômico local ao buscar atrair capital estrangeiro. $\bigcirc$ espaço do Parque Ibirapuera era preenchido, assim, por celebrações dos feitos do passado local e nacional - a tradição -, por meio da Exposição de História, e da modernidade, por meio das vivas atividades industrial e comercial. ${ }^{42}$ 
De tal modo, o lbirapuera estava em sintonia com a forma pela qual as sociedades industriais, já há cerca de um século, faziam-se observar e admirar: as grandes exposições. De acordo com Heloisa Barbuy, as exposições ditas universais, realizadas desde o início da segunda metade do século XIX e cujo apogeu foi vivido entre os últimos anos daquele século e os primeiros do seguinte, eram dedicadas não somente à venda de produtos. Segundo a autora, aquelas exposições vendiam

a ideia da sociedade industrial, do progresso material como caminho de felicidade, no qual todos deveriam congraçar, em harmonia universal; o sonho hegemônico, enfim, da classe burguesa. $\bigcirc$ que se vendia - sim - era um gênero de vida, uma construção política e ideológica, e visões de uma sociedade futura idealizada. ${ }^{43}$

A exibição das benesses da industrialização e o autoelogio das conquistas da inteligência humana se conjugavam numa complexa teia de espetáculos, incluindo museus, teatros, atrações populares, vitrines comerciais. A visão era estimulada das mais diversas formas, causando admiração, maravilhamento. $\bigcirc$ visitante-espectador apreendia visualmente uma infinidade de elementos dispostos de modo a representar o que se supunha como realidade. ${ }^{44}$ Se no auge das exposições universais, nos tempos da Belle Époque, os avanços introduzidos pela industrialização davam sentido à dominação imperial/colonial e à exploração de recursos naturais, constituindo assim também um sentido da história da humanidade e das relações entre povos e com o ambiente ${ }^{45}$ (guardadas as devidas proporções de tempo e espaço), a "história de São Paulo no quadro da História do Brasil" extravasava as escolhas museológicas do interior da Oca e se articulava com toda a atmosfera que envolvia o Parque Ibirapuera, a Feira Internacional e as próprias modificações do tecido urbano paulistano.

Palácio de Exposições e a narrativa histórica nele contida poderiam transformar o olhar do visitante que optasse por prosseguir seu passeio visitando os outros pavilhões do parque em uma atualização do discurso histórico paulista. $\bigcirc$ momento de balanço encetado pela imensa gama de atividades e intervenções planejadas para comemorar os quatrocentos anos da fundação da capital paulista tinha, no Parque Ibirapuera, sua maior e mais eficaz síntese: amalgamavam-se projeções de um futuro moderno, de um presente digno de celebração e de uma narrativa épica do passado. europeias de então se fazia representar naquelas exposições. Àquela época, a corrida imperialista, apoderando-se de recursos dos continentes africano, asiático e oceânico, culminaria nas grandes guerras mundiais (Thomaz, 2002, p. 202-203). 
46. O Estado de S. Paulo, São Paulo, 13 mar. 1955, p. 9 .

47. As informações referentes aos objetos, legendas e demais elementos da exposição apresentadas neste artigo constam do catálogo inédito elaborado por Jaime Cortesão, datilografado, arquivado em seu Espólio (BNP/ACPC, E25, Caixa 64/ Pasta 20, 308 f.). Considerando que se trata de um texto não publicado, com paginação que recomeça a cada seção, todas as referências a seguir sobre a composição da mostra remetem ao mesmo documento citado nesta nota.

\section{A EXPOSIÇÃO DE HISTÓRIA DE SÃO PAULO NO QUADRO DA HISTÓRIA DO BRASIL}

\begin{abstract}
Em vez d'um cerzido de anedotas e episódios mais ou menos pitorescos, imitando as histórias em quadrinhos e as consabidas gravuras de certos compêndios escolares, propusemo-nos pois a organizar um panorama-síntese da história de São Paulo como decorrência lógica e orgânica de fatores geopolíticos, étnicos e culturais dando relevo e expressão viva à estrutura urbana de São Paulo e a os fatos capitais que marcaram a sua contribuição fundamental para a formação geográfica e políitica do Brasil. ${ }^{46}$
\end{abstract}

De acordo com a concepção de Jaime Cortesão para a mostra, pretendia-se um olhar menos convencional e factual, enfatizando uma perspectiva que sintetizasse fatores e processos que explicariam os rumos da história local, bem como marcariam sua singularidade no quadro da história, da geografia e da política brasileiras - termos aos quais Cortesão frequentemente recorreu para narrar a história da formação territorial do Brasil, seu objeto maior de investigação. O texto anteriormente disposto fez parte de uma série sobre a exposição assinada pelo próprio autor publicada n'O Estado de S. Paulo.

A primeira das nove seções - $\bigcirc$ Descobrimento dos Litorais - estava diretamente inserida no quadro da história das navegações portuguesas e trouxe as mais anunciadas peças da mostra: os originais do Tratado de Tordesilhas, em espanhol; da Carta de Caminha, em vitrine nomeada como "Auto do Nascimento do Brasil" e da Carta de Mestre João, primeira figuração da constelação do Cruzeiro do Sul. Estes documentos foram emprestados pelo Arquivo Nacional da Torre do Tombo, um dos principais cedentes de peças para a exposição. ${ }^{47}$

A imagem (Figura 1) apresenta um aspecto da primeira seção, no qual figura em destaque uma rosa dos ventos estilizada em vidros coloridos e iluminada de dentro. A imagem indica uma linha progressiva entre os painéis e vitrines, compondo uma sequência temática e cronológica. Considerando estes aspectos, o ponto inicial de toda a mostra era a Partida das naus do Restelo e a chegada das naus ao Brasil, representada por um mural de Manuel Lapa (Figura 2), artista modernista português que participou ativamente de todos os trabalhos junto de outros artistas modernistas. Com as embarcações no centro do mural, marcam-se do lado esquerdo alusões ao embarque em Lisboa e do lado direito o desembarque no Brasil, figurando dois indígenas ao lado do que parece ser um padrão de descoberta. A epopeia das descobertas também era representada por retratos e esculturas do Infante navegador D. Henrique, de São Vicente, de D. Manuel e do Infante Santo D. Fernando (Figura 3). De acordo com o texto das legendas que acompanham estes vultos, São Vicente é identificado enquanto patrono dos descobrimentos e da "primitiva grei paulista", por ter sido o orago da primeira capitania. 


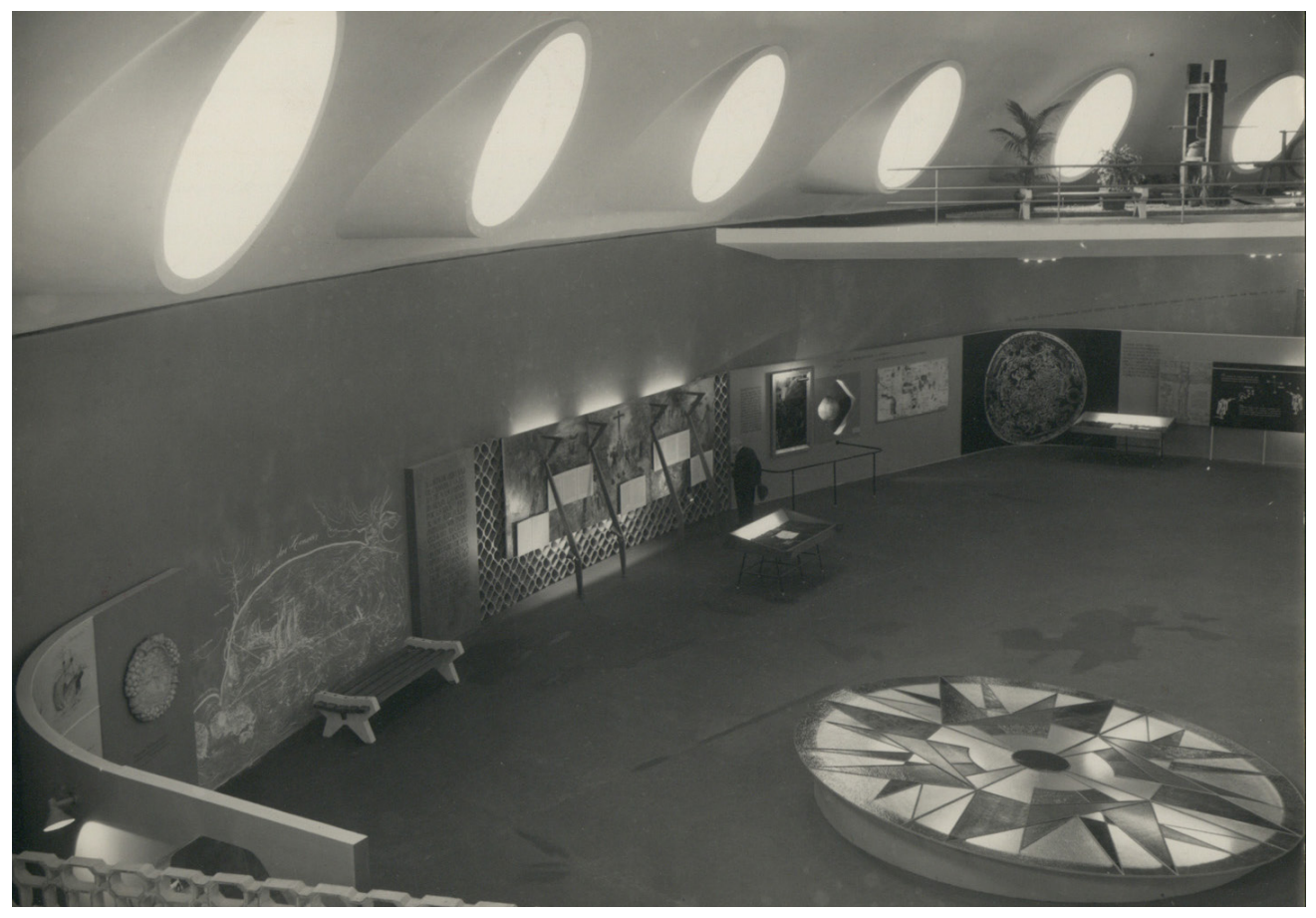

Figura 1 - Aspecto da Seção I, o descobrimento dos litorais. São Paulo, 19 out. 1954. Fonte: BNP/ ACPC, E25/1502. Foto: Fotógrafo não identificado.

Cartas quatrocentistas, anteriores à chegada dos portugueses, punham em questão as primeiras aparições da chamada llha Brasil, bem como as negociações que culminariam na assinatura do Tratado de Tordesilhas em 1494. $\bigcirc$ percurso apresentava os registros que paulatinamente constituíam novas imagens cartográficas do mundo que se ia conhecendo, trazendo por exemplo o planisfério de Cantino (1502) - primeiro seguramente datado em que figura o Brasil - e o globo de Martinho de Boêmia (1492), ambos expostos no sexto painel cujo nome era "Representação da grande revolução geográfica produzida pelos descobrimentos de Colombo e Cabral".

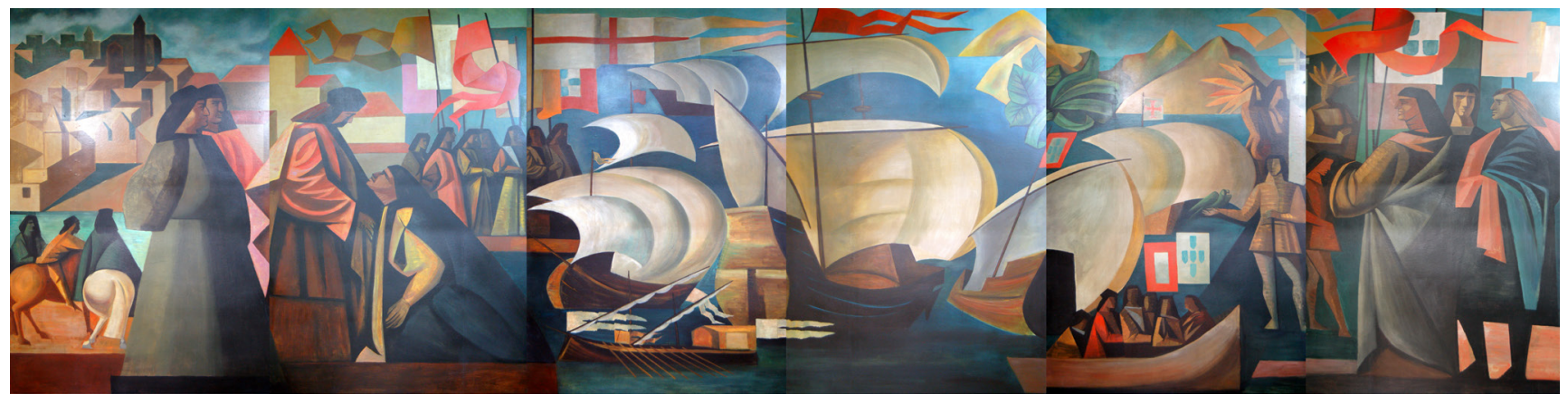

Figura 2 - Restelo, de Manuel Lapa (1060 × 250 cm). Fonte: Acervo da Coleção de Arte da Cidade/Centro Cultural São Paulo. Foto: Emilio Carlos Jeronymo Dantas. 
48. Cf. Jaime Cortesão (BNP/ACPC, E25/33, dez. 1940). A Carta de Lopo Homem (1519) teve autoria e data identificadas em Paris, em reunião na Biblioteca Nacional francesa com a presença de Cortesão.

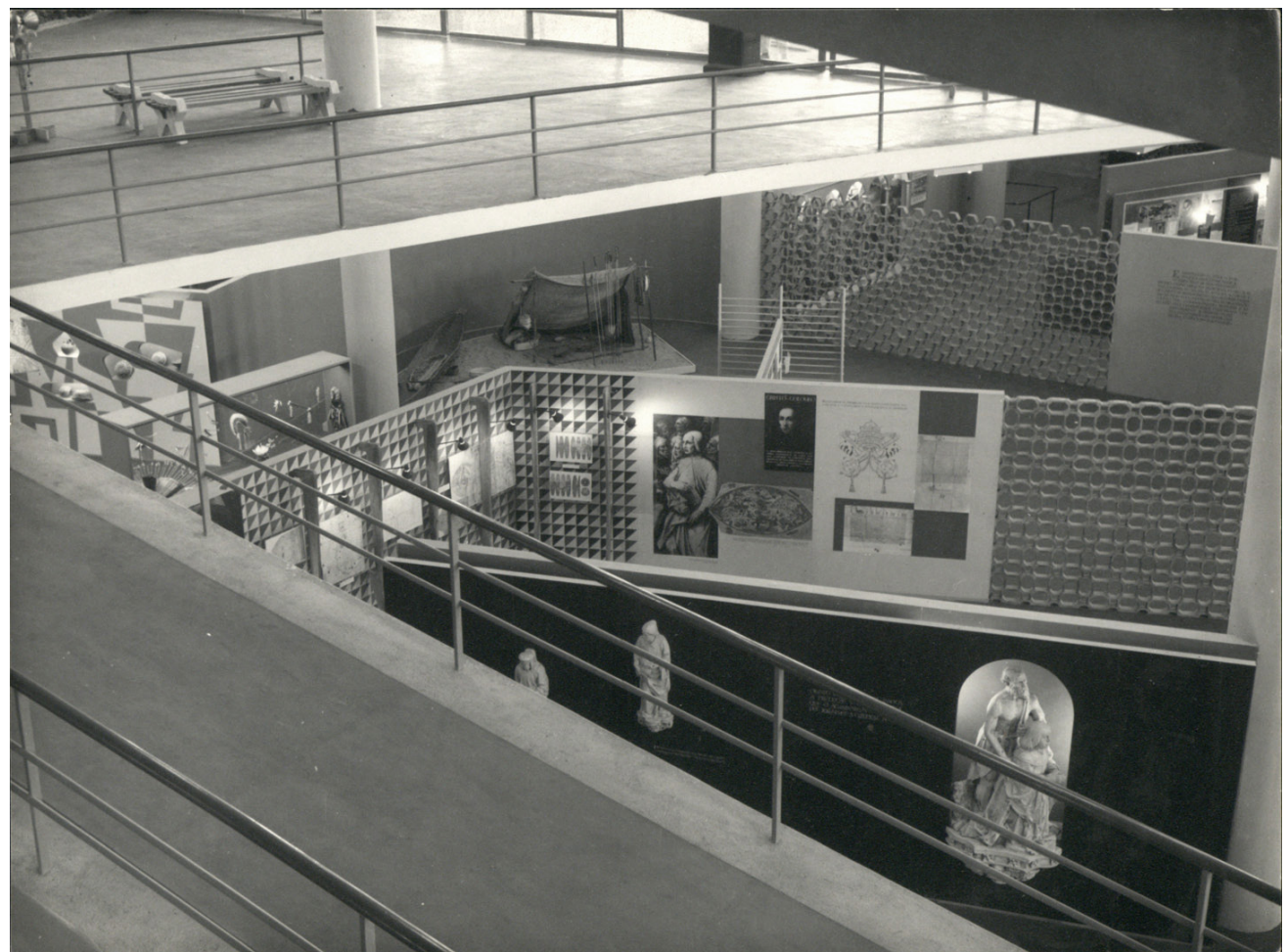

Figura 3 - Partes da Seção I vista de cima. São Paulo, s/d. Fonte: BNP/ACPC, E25/1505. Foto: Fotógrafo não identificado.

A primeira seção apresentava, portanto, aspectos do surgimento do Brasil enquanto iconografia, visível sobretudo na pintura e na cartografia. Tema da segunda conferência de Cortesão realizada em São Paulo em dezembro de 1940, a pintura Adoração dos Reis Magos foi inserida na narrativa como expressão plástica do "sentido ideal da colonização portuguesa: a inclusão do aborígene do Brasil na cristandade", conforme constava na legenda que acompanhava o quadro emprestado pelo Museu Grão Vasco, de Viseu. Catorze anos antes da exposição do original na Oca do lbirapuera, a pintura que traz um ameríndio como o rei mago Baltazar, no lugar em que a iconografia cristã frequentemente representa um rei negro, foi caracterizada por Cortesão no auditório d'A Gazeta como a representação pictórica mais antiga "do Brasil". Segundo o historiador, a pintura foi encomendada pelo bispo de Viseu, que estaria a par das políticas expansionistas da Coroa. Para Cortesão, somente a encomenda por esta autoridade justificaria o ponto de vista representado na pintura da "iniciação em Cristo" do Brasil e do Novo Mundo. Naquela ocasião, o intelectual português apresentava também ao público outro documento manuelino que anos depois figuraria na seção inicial da Exposição de São Paulo, a Carta de Lopo Homem (15 19), considerada a primeira descrição completa do trecho do litoral sul-americano correspondente ao Brasil. ${ }^{48}$ 
A constelação do Cruzeiro do Sul teve na seção um painel em que se apresentaram figuras e fotocópias de gravuras antigas representando observações dos polos por meio de instrumentos de navegação como o astrolábio e a balhestilha. Considerado "desde logo o símbolo da nova grei", o Cruzeiro do Sul também já tinha merecido a atenção de Cortesão em seus textos. Em um dos seus escritos, o autor dá a saber que teve contato com o que identifica como os primeiros registros da constelação, feitos por João de Lisboa e André Pires nos Livros de marinharia, nos arquivos de Paris. ${ }^{49}$

A "mais bela carta quinhentista do Brasil" segundo Jaime Cortesão, o mapa de Lopo Homem foi exposto em ampliação colorida. Segundo a legenda que o acompanhava, os 146 topônimos são demonstrativos da intensa exploração do litoral entre 1500 e 1519, destacando que "o desenho do trecho do litoral, entre a Baía de Guanabara e a llha Grande, revela conhecimento difícil de explicar sem a tentativa de colonização anterior". Além disso, o texto que ladeava o painel, dialogando com o visitante, chamava a atenção para as bandeiras portuguesas dispostas ao norte do delta amazônico e ao sul do estuário platino, como signos da reivindicação de soberania sobre os territórios situados a oeste de Tordesilhas: "para justificar este ambicioso desígnio, o cartógrafo real distendeu todo o litoral brasileiro enormemente para leste, chegando o desvio a atingir 12 graus, na parte compreendida entre o Cabo de Santo Agostinho e o delta amazônico". A informação era parte de um raciocínio amplamente discutido pelo autor. ${ }^{50}$

A legenda do mapa ampliado, cujo original não havia sido cedido pela Biblioteca Nacional da França, fazia ainda uma leitura do documento, apontando para distintivos do território, caracterizados etnográfica e economicamente: os índios "com os mesmos costumes" e a extração do pau-brasil são marcas da carta, bem como a fauna. Uma tradução da legenda do mapa original também era disposta, identificando a região como "grande Brasil", local de gente "escura, selvática e ferocíssima", que "come carne humana" e "maneja com perfeição o arco e as setas". Painéis adiante no percurso e estudos de Armando Cortesão sobre a toponímia desta carta e das de Canério (c. 1506) e Gaspar Viegas (c. 1534) marcavam a centralidade do estudo sistemático da cartografia como relevante na produção da escrita histórica e museológica de Cortesão.

$\bigcirc$ painel de encerramento da primeira seção contou com o apoio do almirante Gago Coutinho, aviador português que fez em 1922 a primeira travessia aérea do Atlântico Sul entre Lisboa e Rio de Janeiro. Coutinho realizou, a pedido de Cortesão, estudos sobre as rotas prováveis de Colombo, Cabral e Vasco da Gama, que foram expostos na mostra em mapas feitos pelo comandante Campos Costa. Segundo Cortesão, as conclusões do aviador indicam que entre as viagens
49. Cf. Jaime Cortesão (BNP/ACPC, E25/36, [1946?]).

50. Cf. Kantor (2007). 
51. Em se colocando lado a lado o programa do Atlas bistórico, a publicação História do Brasil nos velhos mapas e os pontos discutidos em seus cursos no Itamaraty, bem como a linha que norteia a execução da Exposição de bistória de São Paulo permite inferir que se trata, em essência, de um mesmo raciocínio, expresso em linguagens mais ou menos distintas para públicos diversos. de Vasco da Gama e Cabral já havia sido estabelecida a melhor rota para atingir - Brasil, considerando os conhecimentos que eram utilizados pela aviação àquela época. Com a ponte estabelecida pela narrativa da exposição entre o navegador e o aviador, pioneiros nas rołas sul-atlânticas, ressaltava-se o conhecimento geográfico como próprio dos portugueses: no passado e no presente, eram os lusos a estabelecer as ligações entre a Europa e o Atlântico Sul. Aquele oceano era portanto um espaço desbravado e conhecido pelos portugueses, povo a ele vocacionado, e entendido como a própria extensão do território da pequena nação ibérica.

Expondo também diversas cartas da mapoteca do Itamaraty, Cortesão apresentou ao longo da seção de abertura as premissas que orientaram os cursos que ofereceu no âmbito do Instituto Rio Branco, essencialmente expressos na obra História do Brasil nos velhos mapas (1957) bem como o projeto não concretizado do Atlas histórico do Brasil. Ideias-chave como a descoberta dos litorais, os fundamentos geográficos do Estado brasileiro, a realização geográfica, a unidade, entre outras, são características de seus escritos sobre o processo que nomeou como de formação territorial do Brasil. ${ }^{51}$

Após descrever o ato de plantar padrões na costa, como o marco encontrado em Cananeia exposto na primeira seção, e de descrever as gentes, a natureza e o território na literatura, na cartografia e na pintura, deu-se na segunda seção "uma forma lógica e viva à Exposição" por meio da narrativa do "encontro do português, ao desembarcar, com os aborígenes". $O$ encontro entre o índio e o português foi descrito, conforme indica o texto introdutório do catálogo, como a matriz de "muitos aspectos específicos da cultura brasileira e, mais designadamente, da paulista". No mesmo texto, considera-se tal encontro enquanto reação da cultura portuguesa às "formas tão diversas da cultura indígena".

A segunda seção - A cultura do índio e do adventício - foi aberta com um texto indicando ao visitante o processo que seria descrito nos próximos passos de seu percurso por dentro da Oca: "Os primeiros colonos, para sobreviver, tiveram que adaptar-se à cultura aborígene, isto é, tupinizaram-se: nos processos de caça e pesca, na alimentação, no vestuário, nos utensílios, na vivenda, nos lazeres". Ao que se qualifica como pertencente à cultura indígena, dedicou-se um pequeno segmento onde figuravam objetos como os mostrados na Figura 4. Agrupavam-se, de acordo com o descrito no catálogo, imagens e representações dos Tupinambá, desde as do viajante alemão Hans Staden (1547) aos Tupi contemporâneos, em três conjuntos: desenhos de costumes indígenas segundo o livro de Staden; fotografias de Tupi em atividades cotidianas, como o transporte de caça e o 
descascar da mandioca; desenhos de objetos, como cesta de transporte de carga, arco, flechas, rede, espremedor de mandioca. Conforme a introdução do catálogo, "escolheu-se como modelo para figuras indígenas, e por motivos óbvios, o tupi, como aparece nas gravuras da obra de Hans Staden". Salta aos olhos o que seriam os tais "motivos óbvios" da opção pelos Tupi que, de acordo com o que se diz na sequência, estão ligados "às origens da Capitania de S. Vicente". Essa foi uma discussão constante entre os historiadores paulistas, ávidos pela eleição de um modelo heroico de antepassado nativo, operando a partir do binômio Tupi/Tapuia para se referir aos índios. Tais categorias expressavam uma oposição o ente dócil e o arredio, o civilizado e o selvagem, respectivamente..$^{52}$

Baseando-se essencialmente na cultura material - e é este o conceito que traz o texto de introdução ao catálogo -, nos registros de viajantes e nas fotografias desses mesmos povos à época da exposição, pretendia-se apresentar o passado e o presente dessas sociedades numa perspectiva construída com "a colaboração preciosa do jovem mestre da etnografia índia, Darcy Ribeiro, diretor do Museu do Índio do Rio de Janeiro", museu este que emprestou todas as peças expostas no primeiro setor da segunda seção.

No interior da vitrine que aparece no primeiro plano da fotografia (Figura 4), adornos de cabeça, colares de penas, dentes e contas, entre outros, estão dispostos próximos a objetos cerâmicos e vestimentas, também representadas em desenhos ampliados. Na sequência, a cerâmica se destacava no interior de uma vitrine composta por objetos karajá como bonecas e esculturas de animais. Junto desse grupo, fotografias de cenas cotidianas xavante e de outros povos, provavelmente Karajá, foram apresentadas. A cerâmica foi ainda apresentada por meio de mapas sobre a distribuição dessa técnica pelo território brasileiro, identificando especialmente os grupos Guarani, Tapajó, Marajoara e Kadiwéu como seus principais artífices. $\bigcirc$ tema da seção que leva o nome da "Cultura do índio" foi encerrado com uma instalação que demonstrava um acampamento de praia karajá, com paravento armado, esteiras, canoa, cuias, cestos, pratos, rede, lança, entre outros objetos.

Sem legendas que oferecessem maiores informações sobre os objetos e cenas apresentados, o assunto foi encerrado com um texto que ao mesmo tempo introduziu as "culturas antigas" representadas a seguir. Como anunciado pela introdução do catálogo, os elementos que tornaram presentes as culturas indígenas selecionadas para participar da mostra foram dotados do sentido oferecido pelas legendas de abertura e ora pela de encerramento. A referida adaptação portuguesa, de acordo com esta última, teria sido responsável pela implantação de "princípios de uma civilização própria", radicada em todas as matrizes que vinham a seguir, 
especialmente na "cultura náutica, na organização política", e na "amorabilidade franciscana". Para o visitante, o trecho inicial da segunda seção oferecia, sobretudo a partir da interpretação das legendas, uma compreensão dos povos indígenas como culturalmente estáveis, apresentando tradições e produções que teriam restado imóveis. À essas culturas, o adventício se adaptaria e implementaria seu padrão civilizacional, construído há tempos pelas diversas influências recebidas de culturas antigas e medievais. Nesse sentido, narrava-se na exposição uma história em que, a despeito da relevância dada às culturas indígenas - ainda que se desse ênfase apenas às Tupi -, o timoneiro seria o português.

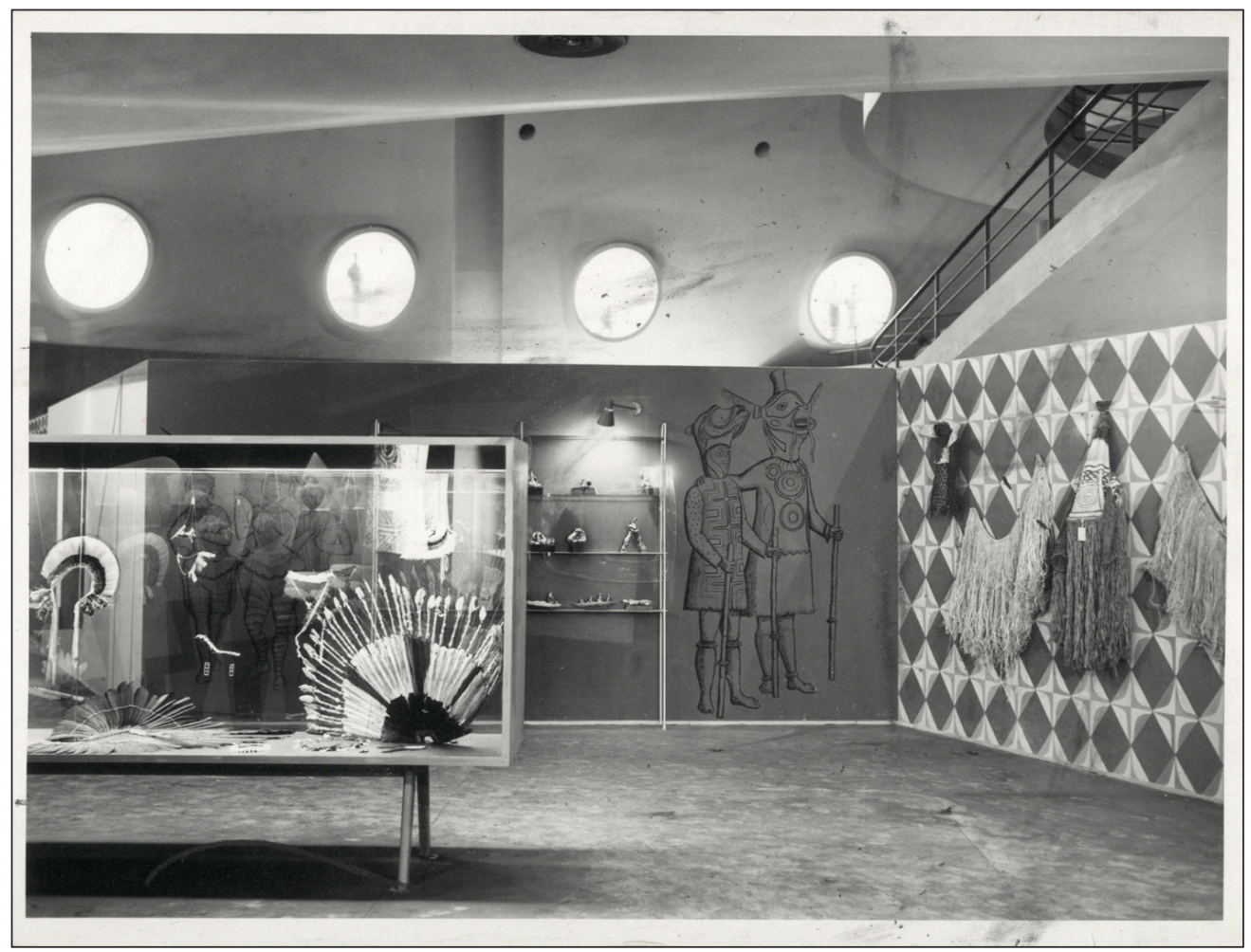

Figura 4 - A cultura do índio, que abre a Seção II da Exposição de história. São Paulo, 13 set. 1954. Fonte: BNP/ACPC, E25/1488. Foto: Bernardelli.

Para caracterizar a cultura portuguesa que aportava e entrava em contato com o índio sul-americano, o caminho partia das culturas antigas, vistas a partir das contribuições deixadas às culturas modernas. Dos antigos, gregos, romanos e hebreus são distinguidos como referências. Os painéis a seguir individualizavam as culturas modernas e suas contribuições aos portugueses, em primeiro lugar figurando árabes e normandos. Dos árabes se destacaram o comércio internacional, 
as culturas geográfica, matemática e cosmográfica, a arquitetura e as artes decorativas; dos normandos, as novas vias comerciais, a vida urbana, a burguesia e o espírito laico. Ambos ganharam painéis sintéticos com textos apresentados de forma bastante distinta das culturas de outros povos.

Do medievo, do renascimento e da era moderna, as culturas italiana, francesa, inglesa, holandesa e espanhola tinham sua presença justificada por serem referenciais de países "em maior ou menor grau ligados à história do Brasil". Além de textos que sintetizavam alguns dos aspectos considerados como mais relevantes, objetos e imagens, originais ou reproduzidos, materializavam essas presenças no percurso expositivo. Exemplares, emprestados das Bibliotecas Nacional do Rio de Janeiro e Municipal de São Paulo expunham traços das mentalidades, das letras, das artes e das ciências europeias. Este segmento, das culturas antigas às modernas, trazia também uma imagem de São Francisco de Assis, de propriedade da ordem franciscana da cidade de São Paulo, acompanhada de uma legenda em que se vincula o franciscanismo à preparação para os descobrimentos portugueses por meio da santificação da terra; e uma fotocópia do Juízo final de Michelangelo na Capela Sistina, cuja legenda direcionava o olhar do visitante para a representação de Portugal como "um jovem atleta, arrancando às penas do inferno um índio e um negro presos por um rosário". 53 Em suma, expressavam-se assim traços considerados marcantes da formação cultural portuguesa e que teriam orientado suas ações, inclusive aquelas em relação às terras e aos povos extraeuropeus.

$\bigcirc$ terceiro segmento da segunda seção tratou especificamente da cultura portuguesa, tendo como ponto de partida o comércio e a agricultura no período medieval e apresentando mapas com rotas comerciais portuguesas na Europa medieval e na costa africana no século XV. Os "cultos populares" davam seguimento às definições expostas da cultura portuguesa, enfatizando os cultos do Espírito Santo, de São Vicente e de Santo Antônio. Cada uma dessas devoções merecia destaque por parte dos organizadores: a do Espírito Santo foi apresentada em uma vitrine com objetos, como coroas e bandeiras, relacionados à festividade que celebrava a instauração de um Império divino, na qual se dava a coroação de um menino e um farto banquete. De acordo com a legenda que acompanhava as peças de museus portugueses e brasileiros, a festa se difundiu largamente, dando "ao cristianismo português o caráter de uma religião de descobridores, tendo por missão propagar a Fé e o Império". ${ }^{44}$ São Vicente, o patrono das descobertas e da primeira vila fundada no litoral brasileiro, figurava em uma pintura setecentista de Cristóvão de Figueiredo, pertencente à Câmara Municipal do Porto. Por fim, Santo Antônio, o orador franciscano nascido em Lisboa e que
53. A reflexão de Cortesão sobre o franciscanismo e a formação da cultura portuguesa, especialmente no que se refere às relações com outras terras e povos, está contida em sua obra $O$ bumanismo universalista dos portugueses (1965).

54. Agostinho da Silva dedicou diversas pesquisas a essa festividade e aos sentidos que nela se encerrariam. A esse respeito, cf. Pinho (2007). 
entrou para os cânones como de Pádua, de quem Cortesão se ocupou na introdução do volume inicial da coleção Clássicos e contemporâneos e n'O humanismo universalista dos portugueses, foi representado na exposição por meio de uma imagem barroca emprestada pelo Museu Nacional de Arte Antiga de Lisboa.

Aprofundando o tema da cultura portuguesa, as vitrines e painéis expostos na sequência traziam objetos como as bandeiras das Irmandades de Misericórdia, que fundaram hospitais em Portugal e no Brasil, exemplares d'Os Lusíadas - um da primeira edição de 1572 e outro de 1670, que acompanhou Gago Coutinho e Sacadura Cabral na primeira travessia aérea do Atlântico Sul - ambos do Gabinete Português de Leitura, entre outros documentos. As peças então expostas descreviam as contribuições portuguesas à Europa medieval, renascentista e moderna, especialmente na economia, nas ciências, nas técnicas, nas artes e na religião.

Com destaque especial, a cultura náutica foi representada por meio de objetos de navegação, roteiros e livros, bem como pela miniatura de uma caravela, "criação náutica portuguesa e instrumento que serviu ao descobrimento dos litorais", conforme sua legenda. A Figura 5 apresenta a disposição de tal trecho da mostra. Abaixo da miniatura de caravela provavelmente encontra-se a vitrine com objetos relativos à atividade náutica. Ao lado, o penúltimo painel relativo a Portugal trazia reproduções ampliadas de gravuras antigas representando funções reais no começo do século XVI, tais como a regulação comercial, a administração jurídica, o trato direto com os mercadores do laconicamente referido "tráfico oriental", a fidelidade às Ordenações do Reino, entre outras. Encerrando os painéis e vitrines sobre o assunto, um políptico de Manuel Lapa, de traços modernos, representava em cinco quadros os trabalhos agrícolas e pastoris dos portugueses no século de Quinhentos, como se vê nas Figuras 6 a 10 .

A legenda, aludindo a um manuscrito iluminado, inscrevia: "Assim viviam e trabalhavam mês a mês nas fainas agrícolas e pastoris os primeiros povoadores que foram de Portugal para o Brasil". Nesses termos, a descrição e a imagem pretendiam compor, somados aos elementos antes trazidos, uma caracterização idealizada do português que aportou no Brasil, destacando as diversas qualidades construídas a partir de influências diversas de outros povos. Procurou-se singularizar os tidos como mais típicos aspectos culturais lusitanos, com o objetivo principal de "restituir a civilização brasileira, quer à sua maior profundidade histórica, quer às suas relações de origem com a história de Portugal", de acordo com o texto do catálogo. 


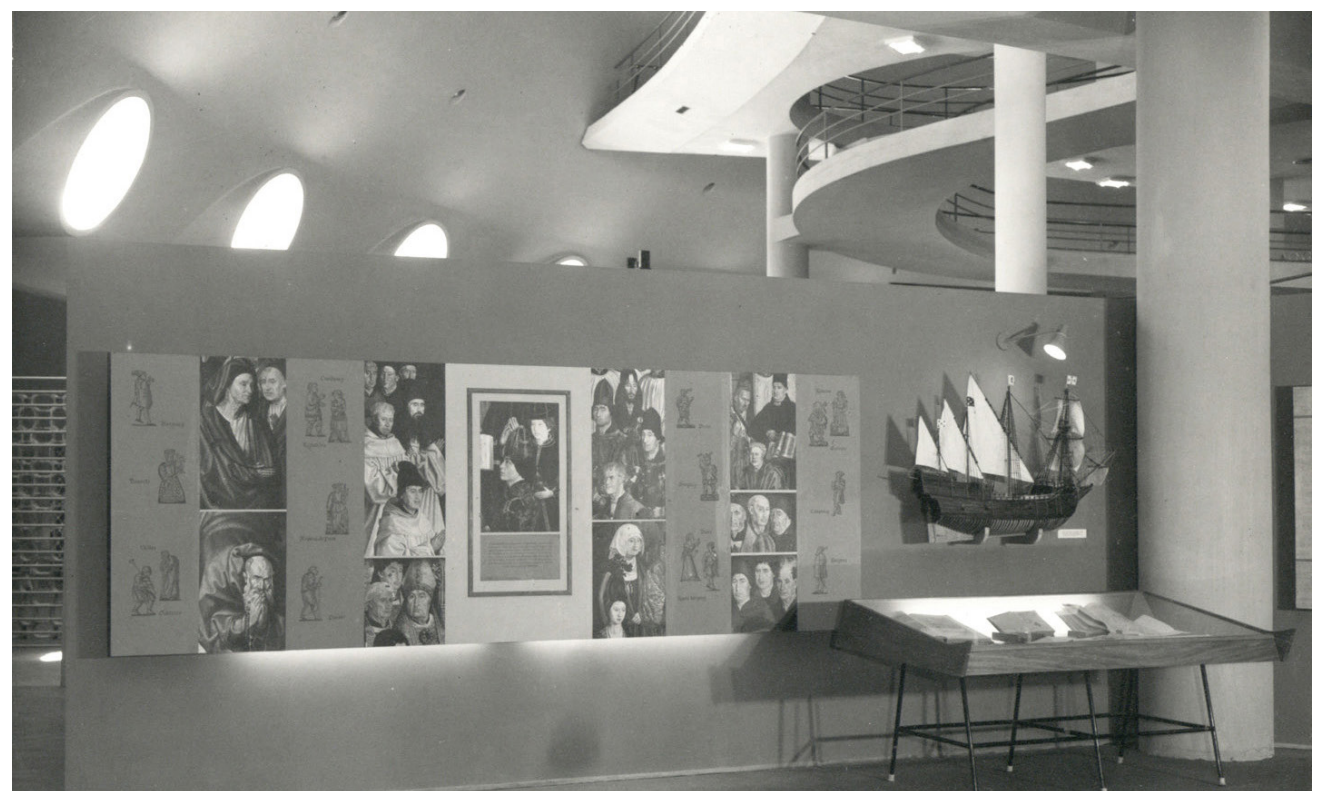

Figura 5 - Aspectos da cultura portuguesa. São Paulo, s/d. Fonte: BNP/ACPC, E25/1503. Foto: Fotógrafo não identificado.

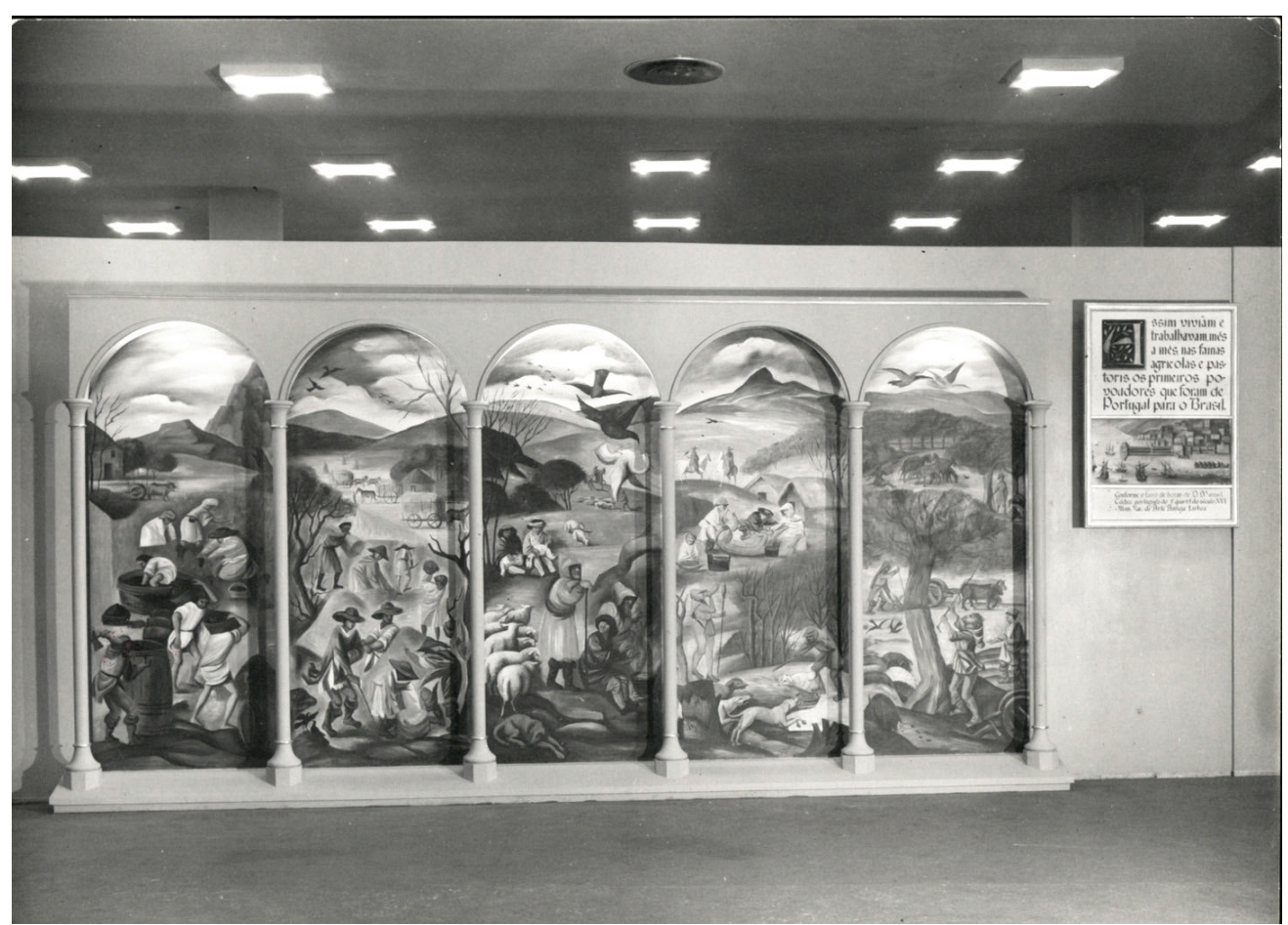

Figura 6. "O povo português do século de Quinhentos nas fainas pastoris e agrícolas". São Paulo, $\mathrm{s} / \mathrm{d}$. Fotógrafo não identificado (BNP/ACPC, E25/1500). As figuras 7 a 10 apresentam quatro partes deste políptico que pertencem ao acervo do Museu Paulista da USP; o painel central tem paradeiro desconhecido. 

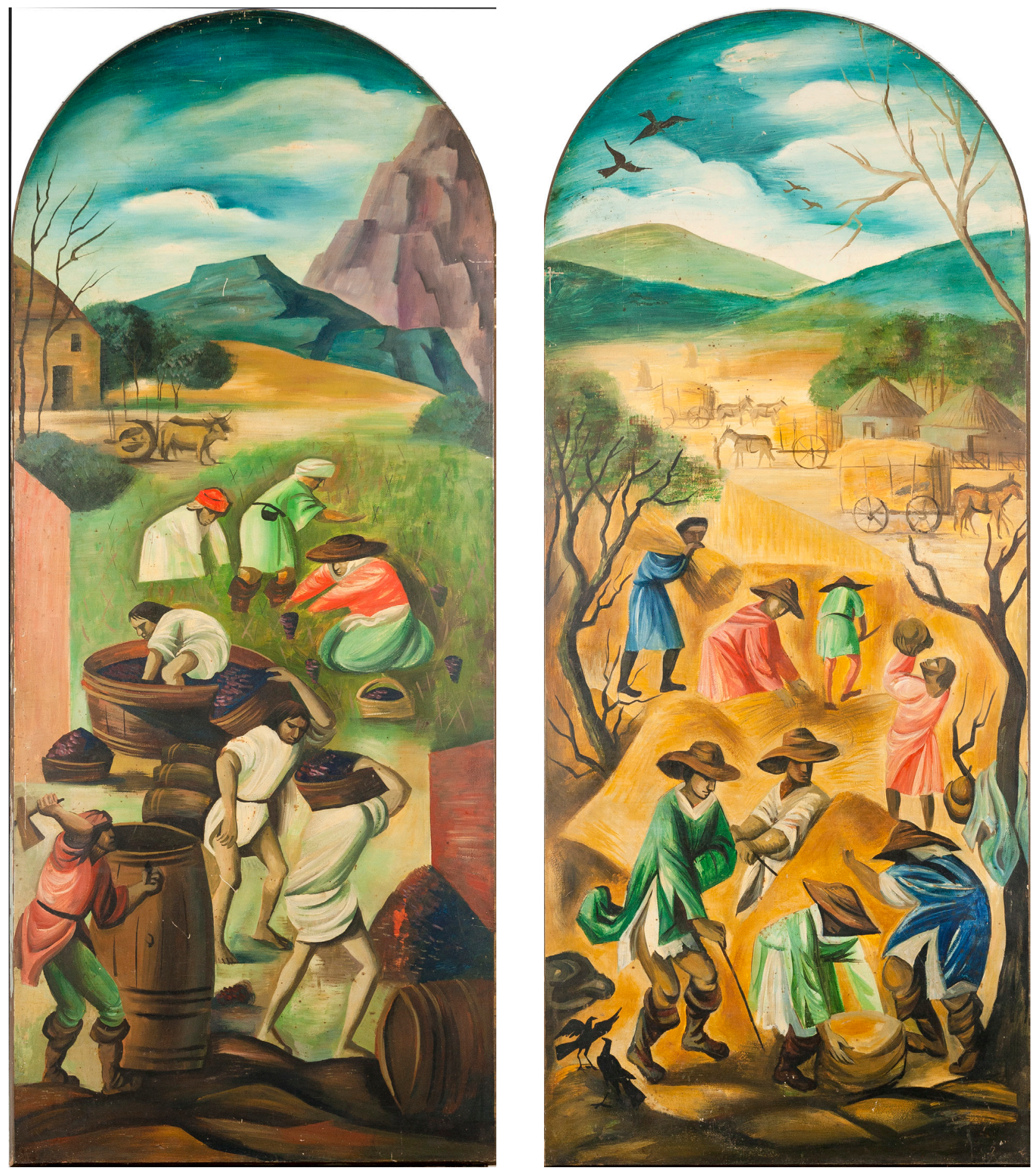

Figuras 7 e 8 - Partes do políptico "O povo português do século de Quinhentos nas fainas pastoris e agrícolas", de Manuel Lapa. Fonte: Acervo Museu Paulista. Foto: Hélio Tengnom Nobre. 

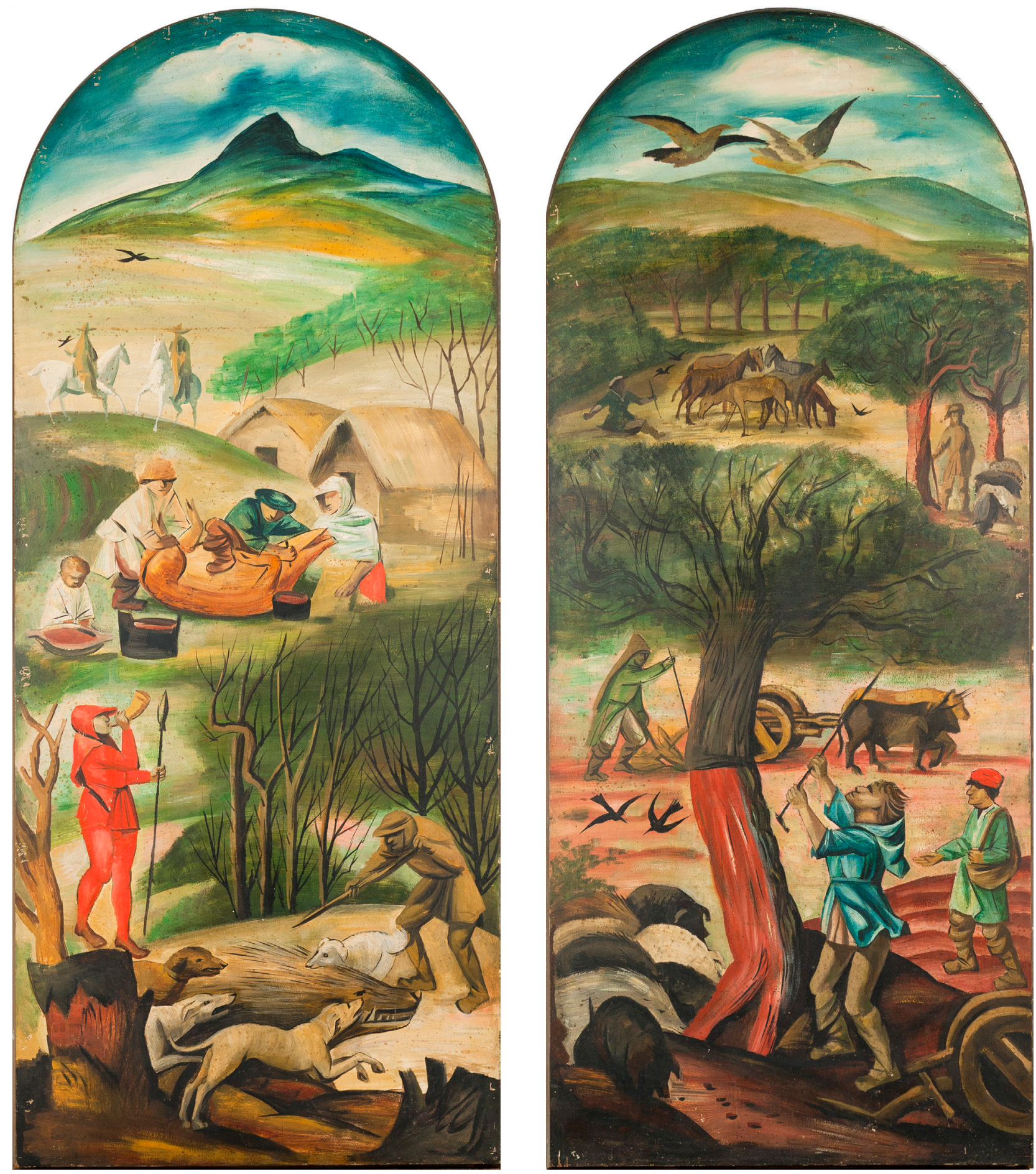

Figura 9 e 10 - Partes do políptico "O povo português do século de Quinhentos nas fainas pastoris e agrícolas", de Manuel Lapa. Fonte: Acervo Museu Paulista. Foto: Hélio Tengnom Nobre. 
Finalizando a segunda seção e enquadrado igualmente na categoria adventícia, um segmento de um único painel era "representativo da arte negra da África portuguesa: Guiné, Angola e Moçambique". Além de "desenhos indígenas d'África", do Museu Agrícola do Ultramar, objetos sem cedentes identificados eram descritos somente em relação a sua origem. Eram três máscaras e dois flamingos de Angola; duas ânforas de São Tomé e Príncipe; um vaso policromado e um hipopótamo da Guiné; um feitiço do Congo; um banco de soba de Luanda e outro de Moçambique. A única legenda a caracterizar o segmento final é a mesma que encerrava a seção: "Da presença simultânea e das influências recíprocas de três culturas, a do índio, a do português e a do negro, numa terra nova, vai surgir uma nova grei". A segunda seção, portanto, deu visibilidade à longa discussão sobre as três raças, ideia bastante recorrente na historiografia brasileira e no senso comum desde Karl von Martius. Não só pelo espaço dedicado a cada um destes que são considerados os três elementos fundadores da identidade brasileira, como também pela forma de sua apresentação e descrição, pode-se perceber a valoração dada a cada um na composição da nacionalidade, sustentando a ideia de uma hegemonia europeia/portuguesa na constituição da gente, da cultura, da técnica, das artes e da ciência brasileiras.

Na terceira seção - A fundação de São Paulo e o pré-bandeirismo Cortesão apresentou a tese de que "a fundação de São Paulo foi um ato fluido no tempo e múltiplo na ação, com profundas raízes pré-históricas, mas cuja realização, sob a espécie histórica, decorreu entre os anos de 1532 e 1560". Nesse sentido, a data de 25 de janeiro de 1554 "representa ou deve representar uma simplificação simbólica, útil para efeitos comemorativos, mas que envolve o risco de nos fazer esquecer o significado complexo da fundação", este compreendido nas ações de Martim Afonso de Sousa e do padre Manuel da Nóbrega, nas vilas fundadas no campo e que acabaram por se consolidar em torno do colégio jesuítico instalado sob a proteção do apóstolo Paulo.

A seção celebrava os "primitivos povoadores de S. Vicente", com especial relevo para João Ramalho, que teria apontado, conforme o catálogo, "aos demais portugueses o caminho do planalto e as vantagens de estabelecer ali um povoado regular, com base na iniciativa do Estado e nas Ordenações do Reino". Também nesse trecho da exposição se deu grande importância "ao passo do 'Diário de Pero Lopes' sobre a fundação de S. Vicente e Piratininga, quer pela sua importância como documento basilar sobre essa dupla fundação, como pela elevação dos termos com que o irmão de Martim Afonso se the refere". Outro documento destacado da seção foi a Carta da Imperatriz (Isabel, irmã de D. João III) de 17 de fevereiro de 1531, segundo a qual Gonçalo da Costa, um dos pioneiros de 
São Vicente, depois de falar ao rei português, informou à imperatriz que "Martim Afonso e os seus companheiros de expedição levavam, como um dos objetivos fundamentais, fortificar S. Vicente e 'desde esse porto que está na sua demarcação, pensavam entrar por terra ao rio da Prata'".

Dentre as discussões levantadas nesta seção, salientava-se que embora se atribuísse importância à ação jesuítica no planalto desde meados do XVI, não se podia deixar de lado as iniciativas "fecundíssimas em consequências" dos moradores civis na criação de uma economia peculiar ao planalto, centrada na criação de gado e de uma indústria primitiva de ferro. Se a primeira era fundamental para a manutenção da vila, a segunda serviu "de base às trocas vitais pelos produtos indígenas, que atou as sólidas relações de convivência e comércio com as tribos do interior e foi o verdadeiro prólogo à penetração nos sertões". As Atas da Câmara de São Paulo serviram na exposição como importantes documentos a respeito dessas iniciativas civis, especialmente o surgimento dessa criação de gado. A instalação da Câmara em 1560 representou, de acordo com a narrativa construída pela mostra, a fundação de um "baluarte do espírito de liberdade e autonomia e defesa do sentido de vida independente e expansionista, que havia de caracterizar o bandeirismo". Esta interpretação do processo de fundação da cidade foi também exposta, nos mesmos termos, em A fundação de São Paulo: capital geográfica do Brasil, obra de Cortesão lançada em 1955 pela editora carioca Livros de Portugal, de um de seus amigos patrícios.

A terceira seção foi aberta com um mapa da Vila de São Vicente, reproduzido do original de Alonso da Santa Cruz, cosmógrafo espanhol que esteve na região em 1530, conforme apontava a legenda, e que a havia descrito como "um povoado de dez ou doze casas, uma feita de pedra com seu telhado e uma torre para defesa contra os índios em tempo de necessidade". Segundo o cosmógrafo, "nessa povoação e nesses povoadores afunda suas raízes a futura vila de São Paulo de Piratininga", o que sugeriria, de acordo com a interpretação de Cortesão, a dita pré-fundação de São Paulo, o marco inicial do processo que se estenderia pelas décadas seguintes.

Os primeiros povoadores de São Vicente - João Ramalho, Gonçalo da Costa e Antônio Rodrigues - foram representados por Manuel Lapa. Na legenda, um trecho selecionado do Diário de Pero Lopes de Sousa (1532) deu sentido às três figuras, narrando as determinações do capitão Martim Afonso e de seu grupo: "A todos nos pareceu tão bem esta terra que o capitão determinou de a povoar e deu a todos os homens terras para fazerem fazendas", estabelecendo uma vila na itha de São Vicente e outra "nove léguas dentro, pelo sertão, à borda de um rio que se chamava Piratininga", repartindo as pessoas nas duas povoações e dotando- 
as das estruturas pertinentes de então. Um retrato de Martim Afonso, também por Manuel Lapa, foi apresentado em destaque na sequência, outorgando-the junto ao rei de Portugal "a glória [...] de ter fundado a vila de Piratininga, na consciência das suas vantagens de posição como base da formação territorial do Brasil". Comunicava-se assim o sentido da fundação de São Paulo em relação à história da formação territorial do Brasil, fruto de determinações da Coroa. Nas vitrines a seguir, documentos expostos, emprestados do Arquivo Nacional da Torre do Tombo, apresentavam registros relacionados às ações dos primeiros povoadores. Duas pedras quinhentistas do acervo do Museu Paulista complementavam o quadro dos anos iniciais da colonização.

Do original levantado na Sociedade de Geografia de Lisboa, uma versão fac-similar do mapa de Gaspar Viegas (1534) foi exposta no painel que trazia uma sequência de documentos cartográficos a fundamentar a tese da fundação de São Paulo como a capital geográfica do país. Registrado como representativo dos "novos conhecimentos geográficos adquiridos pela expedição de Martim Afonso", o mapa de Viegas foi também sobreposto a um mapa contemporâneo, conduzindo à leitura de que "D. João III pretendia abranger na soberania portuguesa todo o vale do Prata". Além disso, "pelo traçado do Paraná e de seus afluentes terminais", o referido mapa permitia a conclusão, segundo Cortesão, que a fundação da vila de Piratininga perto do Tietê por Martim Afonso demonstrava a "consciência do grande valor dessa posição geográfica que permitiria a expansão do Brasil na direção do Prata". Ainda no painel, parte de um planisfério de André Homem (1559), no qual o Brasil figura como itha, compunha a reflexão complementada pela Carta de Bartolomeu Velho (1562), que também apresenta o Brasil como itha, dessa vez limitada pelos rios Paraná e Tocantins, unidos pela lagoa Eupana. Ary Duarte, cartógrafo que trabalhou junto de Cortesão no Itamaraty e na edição de A Fundação de São Paulo e de outras obras, elaborou um mapa demonstrando as "grandes penetrações portuguesas anteriores às bandeiras", como a chamada protobandeira de Aleixo Garcia (1522) e a de Antônio Rodrigues (1536-1542).

Mais dois painéis com mapas diversos do século XVI, incluindo holandeses e portugueses, buscavam dar conta das representações da América do Sul, das costas africana e sul-americana e da região andina. Outros três mapas apresentados também foram produzidos especialmente para a exibição, executados por uma equipe coordenada pelo engenheiro César Bierrenbach de Lima, com dados do arquivo Aguirra: tais mapas deram início a uma série distribuída pelas seções relativa à "marcha da ocupação e desbravamento do território paulista e ao crescimento da área urbana de São Paulo". Os três representavam: (1) os pequenos 
povoados que existiam em 1554; (2) São Paulo de Piratininga em 1560; (3) sesmarias pedidas ao redor de São Paulo, datadas do século XVI.

Três desenhos do artista português Fernando Lemos, alusivos às fundações de Santo André, Bertioga e Itanhaém, apresentaram num painel os "pródromos da fundação de São Paulo", ladeados por trechos de uma carta de Tomé de Sousa ao rei de Portugal datada de junho de 1553, em que se mencionavam os muitos filhos e netos de João Ramalho, o natural do termo de Coimbra que tinha sido feito capitão da vila de Santo André. Outro trecho da carta de Tomé de Sousa foi evocado junto ao painel posterior, para o qual os artistas da exposição ${ }^{55}$ produziram um desenho relativo ao conhecimento dos caminhos fluviais entre o Planalto de Piratininga e Assunção. Na correspondência ao rei, Tomé de Sousa identificava a cidade como próxima de Assunção, a uma distância de cerca de cem léguas.

Entre esse ponto da narrativa exposta e os painéis dedicados à data central das comemorações daquele 1954, o destaque foi dos jesuítas, ordem religiosa intimamente ligada à história da fundação piratiningana e vivamente difundida na iconografia comemorativa ao lado dos bandeirantes e dos índios. ${ }^{56}$ Em uma vitrine, o original e as reedições de $\bigcirc$ diálogo da conversão do Gentio (c. 1557), escrito por Manuel da Nóbrega, eram alguns dos documentos expostos. Seria essa a primeira obra escrita no Brasil que não era do gênero epistolar. Das diversas edições lançadas, destaca-se a última, publicada em Lisboa em 1954 "sob os auspícios da Comissão Portuguesa do IV Centenário de São Paulo". Junto desses documentos, apresentava-se a medalha cunhada pelo governo português em homenagem à festa centenária da fundação de São Paulo.

A fundação de São Paulo - o evento de 25 de janeiro de 1554 - foi concentrada na figura do padre Manuel da Nóbrega, a cuja ação aludia a ilustração feita pelos artistas da exposição. Reforçando o gesto fundador e buscando inspirar um sentimento cívico em quem visitava a exposição, a legenda que a acompanhava chamava Nóbrega de "grande missionário e estadista" perante a quem o Brasil se inclinava. Ao lado de outros jesuítas, o padre teria lançado os novos fundamentos da povoação do planalto e the dado "espírito de continuidade". Um mural de Manuel Lapa, feito com a colaboração de Fernando Lemos (Figura 11 ) representava então a missa da fundação, celebrada em 25 de janeiro de 1554. Em letras gravadas sobre pedra antiga, em alusão aos objetos quinhentistas presentes na exposição, a legenda solene posta aos pés do painel modernista em que figuravam índios, padres e colonos registrava: "25 - janeiro - 1554. $\bigcirc$ Pe. Manuel de Paiva, assistido por outros padres e irmãos leigos jesuítas, reza a missa da conversão do apóstolo que deu seu nome à cidade de S. Paulo". A missa de fundação era representada de acordo com a estética em voga e não nos moldes
55. Segundo a ficha técnica da exposição que consta do catálogo, o grupo de artistas e decoradores era composto por Manuel Lapa (decorador-chefe), Artur Jorge, Fernando Lemos, Arnaldo Pedroso d'Horta, Clóvis Graciano, Emiliano Di Cavalcanti, Estrela de Faria, João Maria dos Santos, Irene de Almeida e Vasconcelos, Miguel Carnicelli Sobrinho, Nelson Nóbrega, Pedro Birkenstein, Tarsila do Amaral, Wladimir Douchkine, Akio Shirakawa, Francisco Cuoco, Francisco Ismael Toledo Falcão, Fukugawa Akira e Gontran Guanaes Neto. Havia na equipe diversos nomes conhecidos do movimento modernista, sugerindo mais relações de Cortesão com o grupo e que iam além de Murilo Mendes, casado com a sua filha Maria da Saudade Cortesão, e de alguns de seus correspondentes, de acordo com o que se encontra no Espólio, como Mário de Andrade, Cecília Meirelles, Cassiano Ricardo, Carlos Drummond de Andrade, alguns deles servidores públicos dos tempos de Capanema.

56. Cf. Lofego (2004). 
57. Trata-se do mural descoberto em 2015 no pavilhão da Oca. Cf. MARTí, Silas. Mural esquecido de 1954 é descoberto atrás de parede falsa na Oca. Folha de S. Paulo, São Paulo, 13 jul. 2015. acadêmicos da virada do século. O público visitante visualizaria então o simbólico ato fundador da cidade de São Paulo de acordo com a estética que dava novas feições ao parque onde se comemorava a grande festa, à cidade e à sua narrativa histórica. Quatrocentos anos depois, fundava-se a cidade moderna.

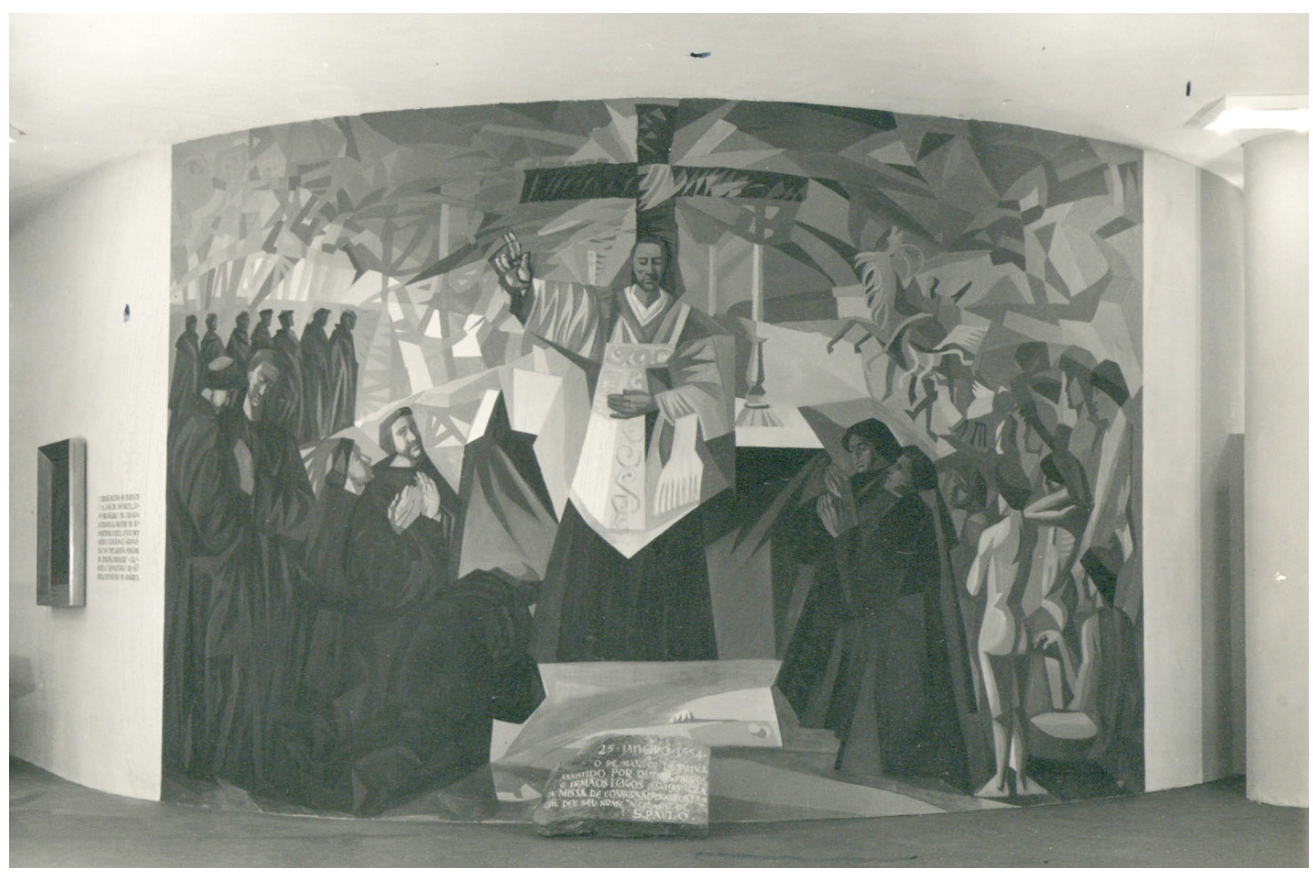

Figura 11 - Missa de 25 de janeiro (Conversão de São Paulo) de 1554. Mural de Manuel Lapa, com a colaboração de Fernando Lemos $(700 \times 500 \mathrm{~cm})$. São Paulo, s/d. ${ }^{57}$ Fonte: BNP/ACPC, E25/1513. Foto: Fotógrafo não identificado.

Dada a ênfase a Nóbrega, era a vez de apresentar aquele que se fixou na memória local como fundador da capital paulista, homenageado com uma estátua próxima ao marco zero da cidade, na Praça da Sé: o canário José de Anchieta. $O$ retrato apresentado em destaque era considerado o mais antigo do jesuíta segundo Rodrigo Melo Franco de Andrade. Na pintura pertencente ao Convento Jesuítico de Anchieta, Espírito Santo, há a inscrição "Ven. P. Joseph Anchieta - Soc. Jesu Brasiliae Thamaturgus". Na legenda, tão elogiosa quanto a que apresentava Nóbrega, Anchieta foi descrito como um "luso-brasileiro, de origem espanhola, mestre de humanidades, poeta, autor dramático, etnólogo, gramático do tupi, refém sublime de Iperoig, primeiro cronista e taumaturgo de São Paulo, Apóstolo da América". Para além da tripla nacionalidade do espanhol tornado luso-brasileiro, diante de quem igualmente o Brasil se inclinava, a série de epítetos justificaria as homenagens ao padre que era tido como o fundador da cidade, ainda que não figurasse na exposição como tal. Sobre os habitantes do 
Campo de Piratininga, um painel apresentou um panorama da economia do planalto, mencionando o gado, as plantações e os hábitos alimentares. Nesse assunto, também se abordou sobre as trocas entre colonos e índios, intercambiando com os ameríndios especialmente objetos de ferro. Não se diz porém nesse painel, em que também figuravam algumas das técnicas introduzidas pelos portugueses como o monjolo, o pilão e o engenho d'água, o que ofereciam os índios.

O último painel da seção, denominado "A criação da Vila" (Figura 12), era composto por três baixos-relevos feitos pela escultora portuguesa Irene de Vasconcelos, esposa de Manuel Lapa. No primeiro, vê-se uma representação da transferência dos moradores de Santo André da Borda do Campo para São Paulo de Piratininga; no que se encontra no centro, a representação é da instituição do pelourinho da vila de São Paulo; no último, está figurada a primeira sessão da Câmara de São Paulo, realizada em 1560, marco final do processo mencionado por Cortesão como a fundação de São Paulo. Nos textos que acompanhavam as representações escultóricas, todo esse processo era descrito: a ordenação para o povoamento expedida pelo rei português a Martim Afonso simbolizava "na fundação de São Paulo a grande capacidade dos portugueses para descortinar as vantagens da posição dos lugares eleitos do planeta"; Manuel da Nóbrega deu

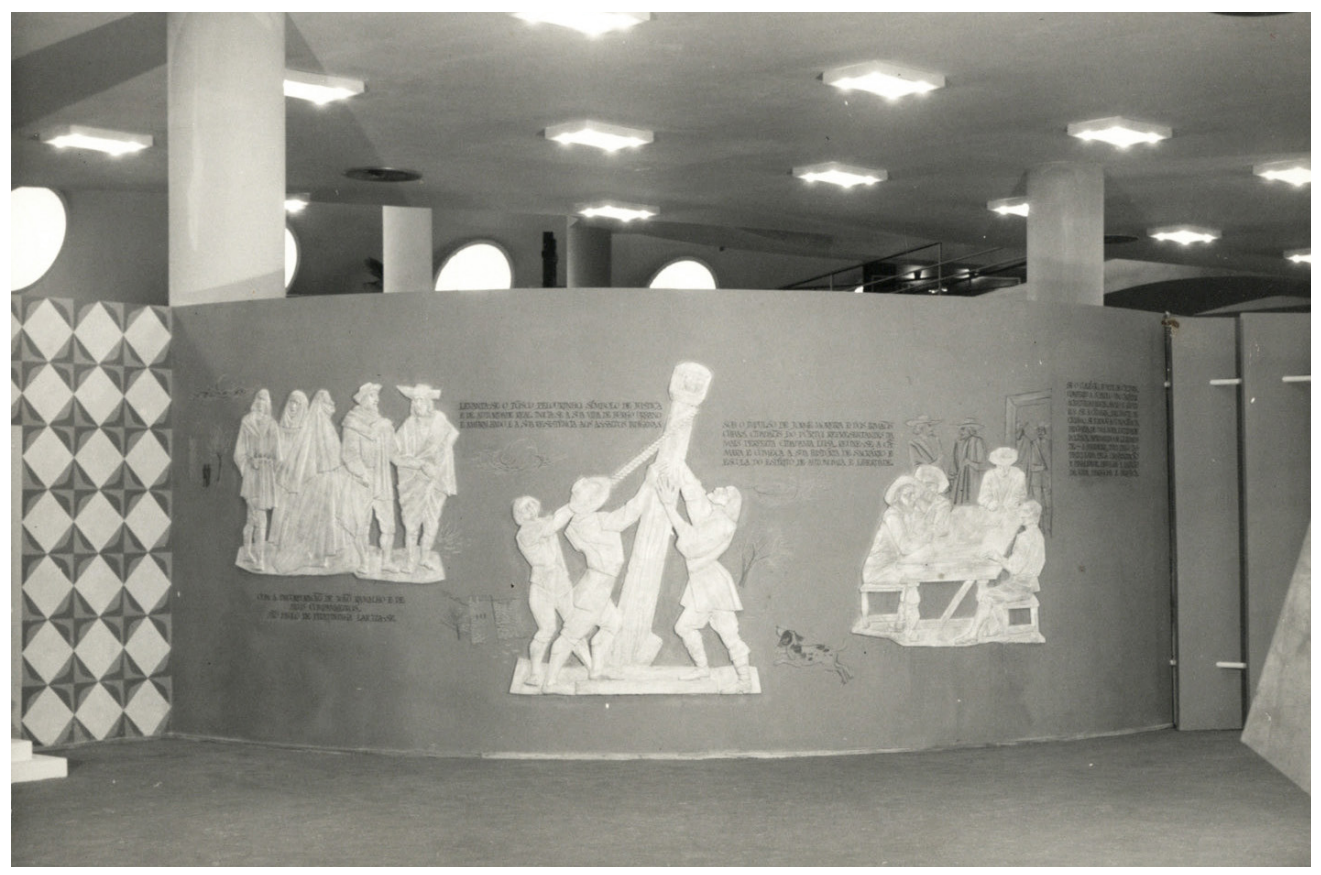

Figura 12 - Baixos-relevos da escultora Irene de Vasconcelos no painel "A criação da Vila" (148 $\times 102 \mathrm{~cm} ; 175 \times 118 \mathrm{~cm}$; sem dimensões informadas). São Paulo, s/d. Fonte: BNP/ACPC, E25/1512. Foto: Fotógrafo não identificado. 
seguimento e estabilizou a primeira fundação; Mem de Sá, impelido por Nóbrega, transferiv o povoado para Piratininga e the concedeu foros de vila. A base de todo o movimento se fundava sobre a geografia, dando sentido àquela fundação que expressava a capacidade portuguesa de apreender o mundo. A liderança de Martim Afonso se fixava no sintético painel final, como o decurso da seção já anunciava.

Nesse sentido, a incorporação de João Ramalho e dos seus laicizava a vila fundada pelos padres jesuítas. O pelourinho representava o marco fundador do início do burgo, símbolo da justiça e do poder real - próximo ao painel, as pedras do pelourinho de São Vicente, pertencentes ao Museu Paulista, eram exibidas - e por fim, os "representantes da mais perfeita cidadania lusa", cidadãos do Porto, a cidade admirada por Cortesão, formaram a Câmara, corporificando o "espírito de autonomia e liberdade". Na Casa "baluarte do civismo", a nova entidade política afirmava sua bandeira - "tupi pelo instinto, lusa pela organização e finalidade" - o que lhe daria "a paixão da vida perigosa e heroica". Próximo às pedras do pelourinho vicentino, o painel sintetizava o espírito presente no processo iniciado por Martim Afonso e concluído com a instalação da Câmara, monumentalizando ali, por meio da linguagem escultórica, aqueles que foram eleitos como eventoschave da formação da municipalidade que então se lançaria para o sertão. Lusotupi, a vila apaixonada pela "vida perigosa e heroica", operaria a partir de sua casa cívica a simbiose entre a "organização" dos primeiros e o "instinto" dos segundos.

Indicando os caminhos que a exposição seguiria a partir de então, três vitrines encerravam documentações das câmaras de Santo André da Borda do Campo e de São Paulo, bem como mapas, atlas e fragmentos de cartas das décadas do século XVI posteriores à sessão de abertura da Câmara de São Paulo. Além de planos das vilas do Rio de Janeiro, da Bahia de Todos os Santos e do Recife, figuravam naquela vitrine reproduções de planisférios e mapas. Ary Duarte compôs para a exposição um mapa da América do Sul conforme Mercator (1569) e um estudo da carta de demarcação portuguesa e espanhola segundo Luiz Teixeira e Lopes de Velasco. Dessa forma, a fundação de São Paulo abria o caminho da revelação dos ditos "segredos geográficos" da entidade territorial brasileira, ponto de vista narrado nas seções seguintes.

A quarta seção - Bandeiras e bandeirantes - procurou "desenvolver e exprimir por forma viva as origens, as causas e as primeiras consequências do bandeirismo, o fato verdadeiramente original, específico e definidor da história de São Paulo". Seguindo a tendência de décadas anteriores sobre o assunto, 
especialmente entre historiadores paulistas - e mesmo da produção dos símbolos da identidade local - bandeiras e bandeirantes expressavam a "grande contribuição [paulista] para a formação geográfica, social e política do Brasil". A seção parte da referência à criação de uma "economia de forma expansionista", que em uma "posição geográfica eminentemente propícia à expansão" levou por sua vez o paulista a se lançar aos sertões.

A questão das origens portuguesas do organismo-bandeira aparecia como ponto inicial dessa seção da exposição, conforme inscrito no painel de Bernardo Marques (Figura 13). Segundo consta, desde 1570 a palavra bandeira era empregada como "sinônimo de companhia de Ordenanças ou de Milícias", entrando no Brasil via São Paulo em inícios do XVII, em um primeiro momento como organismo de defesa e posteriormente, de penetração territorial.

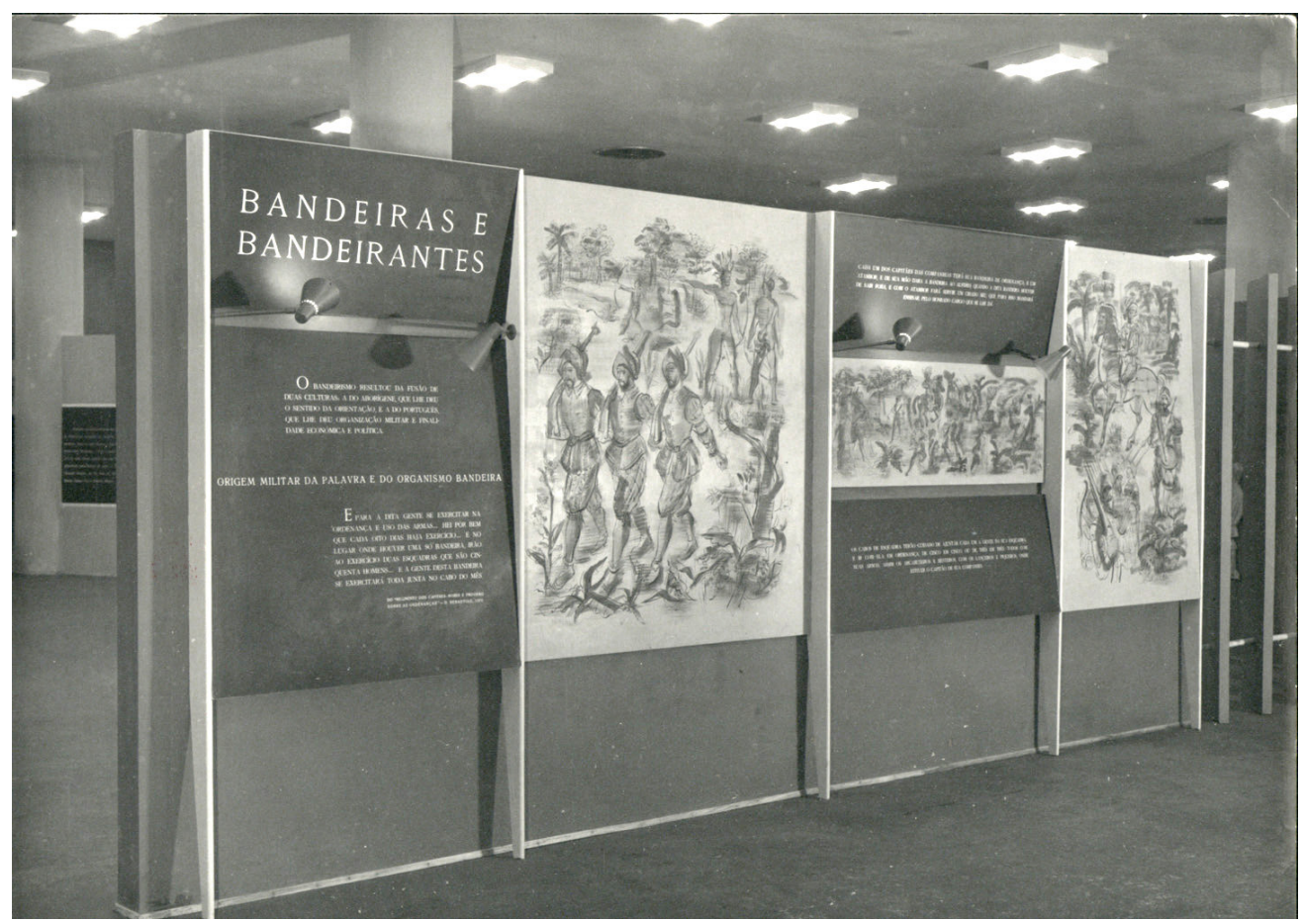

Figura 13 - Seção IV, painel de Bernardo Marques sobre a origem da palavra e do organismo "bandeira". São Paulo, s/d. Fonte: BNP/ACPC, E25/1504. Foto: Fotógrafo não identificado.

De acordo com a linguagem utilizada no texto introdutório do catálogo da exposição, nota-se que as escolhas museológicas de Cortesão também pretendiam trabalhar problemas relacionados à produção do conhecimento 
58. A respeito do mito da "Ilha Brasil" na historiografia, cf. Kantor (2007, 2009). histórico. Um destes que se pretendia esclarecer dizia respeito à definição das fronteiras do Brasil: os estudos de Cortesão apresentados em seus cursos no Itamaraty, bem como nas obras que resultaram de suas atividades naquela instituição, se tornam centrais entre a quarta e sexła seções da exposição. Foi na quarta seção, por exemplo, que o mito da llha Brasil foi colocado como o ponto de partida das ações dos colonos, que buscariam demonstrar a inviabilidade do Tratado de Tordesilhas. Cientes de uma unidade geográfica brasileira, portugueses e luso-brasileiros teriam se dado conta de que os limites daquela terra "deveriam ser traçados em função das duas grandes bacias hidrográficas do Amazonas e do Prata", fronteiras naturais daquela suposta vasta unidade geográfica. Cortesão atribuía então ao Estado português e aos colonos o sonho de "delimitar o Brasil por esses dois profundos acidentes geográficos e vales fluviais, nas suas possiveis conexões".

Diante do sonho, a realidade que se apresentava para aqueles colonos expunha que estes precisariam do conhecimento dos naturais da terra para nela se deslocarem, utilizando, por exemplo, os grandes rios, que seriam então as "estradas naturais". Na seção, o encadeamento da abordagem do assunto enfatizava a finalidade expansionista das bandeiras, apresentando mapas do que seriam o sistema "lógico e necessário das futuras fronteiras", incluindo os fossos e muralhas naturais impeditivos que foram no entanto ultrapassados por Raposo Tavares. Sobre as derrotas sofridas pelos sertanistas conhecidas por meio das narrativas jesúíticas, como ocorrido em Mbororé - da qual mencionavam a resistência indígena armada pelos padres castelhanos -, é dito que os reais motivos do insucesso se deviam não à tenacidade dos nativos, mas sim ao "excesso temerário da sua audácia [dos bandeirantes]", ultrapassando "os limites naturais impostos pela natureza". A unidade geográfica expressa na llha Brasil aparecia na exposição por uma profusão de mapas, atestando a sua transformação na cartografia oficial portuguesa e estrangeira. ${ }^{58}$

A captura de indígenas, já discutida por parte da historiografia local de então às bandeiras e aos bandeirantes, foi exposta, ainda que como secundária diante dos objetivos políticos e econômicos das expedições, ressaltando a mineração. A questão da escravidão indígena não seria portanto destacada. Sobre as motivações políticas das bandeiras durante o período da União Ibérica (15801640), negadas em diversas teses, Cortesão novamente deu o tom de debate que se travaria em torno da quarta seção, mencionando os erros históricos que teriam dado base às interpretações que ora desmentia. Segundo o organizador da exposição, a explicação de que a unificação das coroas sob o domínio filipino 
anularia pretensões políticas às bandeiras era negada a partir da documentação que atestava a manutenção dos termos de Tordesilhas, bem como as condenações impostas por Filipe IV em 1639 aos bandeirantes que ultrapassaram a linha demarcadora.

A chamada lenda negra que se produziu sobre os bandeirantes também fazia parte da seção, sendo desconstruída por meio da apresentação das versões distintas descritas pelo jesuíta espanhol Montoya sobre a bandeira de Raposo Tavares no Guairá (1628-1629), destacando que o padre mencionava as pretensões expansionistas do sertanista. Ao que se nota, pretendeu-se desmistificar a dita lenda desenhando os contornos do que seria uma guerra entre bandeirantes e jesuítas espanhóis. Segundo a documentação ora exibida, a ação de Raposo Tavares contra as reduções seria uma reação à primeira investida armada feita por índios e jesuítas. ${ }^{59}$ Para ratificar a narrativa exposta, apresentavam-se mapas inéditos, como os que resultaram das bandeiras que devassaram o Tocantins e o São Francisco, além dos documentos de origem jesuítica da Coleção De Angelis.

Assim como se evidenciou as origens portuguesas das bandeiras foi destacada a chamada contribuição indígena, que na exposição estava expressa em um grande painel, além de diversos objetos que construiriam uma narrativa pautada pela "continuidade cultural, inerente à formação luso-tupi do bandeirismo". O cartógrafo Ary Duarte produziu uma representação gráfica sobre um mapa da América do Sul identificando as vias indígenas de "difusão cultural", isto é, dos principais elementos introduzidos pelos europeus nas Américas portuguesa e espanhola (Figura 14). Cores diferentes e traços esquemáticos distinguem as vias dos Tupi e dos Aruaque. Também representados por uma convenção carłográfica estão as zonas de "enlaces hidrográficos" que os índios teriam aproveitado para efetivar tal difusão. Entre os elementos, o painel traz o galo, os machados de ferro e os anzóis. Do lado direito do painel, a legenda caracteriza qual teria sido o papel desempenhado pelos indígenas nos deslocamentos para o sertão, "O índio foi a bússola e mapas vivos das penetrações no interior". Abaixo desse texto, uma outra legenda indica as fontes utilizadas para a produção daquele mapa, os estudos de Nordenskiöld. Na ocasião, concluiu em particular que os Tupi e Aruaque "conheciam e praticavam não somente a rede fluvial do continente, mas os mútuos enlaces hidrográficos nas zonas de varadouro". Tais estudos, mobilizados por Cortesão quando trabalhou nos projetos sobre a construção da nova capital do Brasil, faziam entrever uma história das populações indígenas que as coloca a serviço do colonizador português, negando-lhe qualquer agência.
59. Segundo Alencastro $(2000$, p. 335), a interpretação de Cortesão frequentemente se revestia de um olhar que identificava na América do Sul os embates ibéricos entre portugueses e espanhóis. 


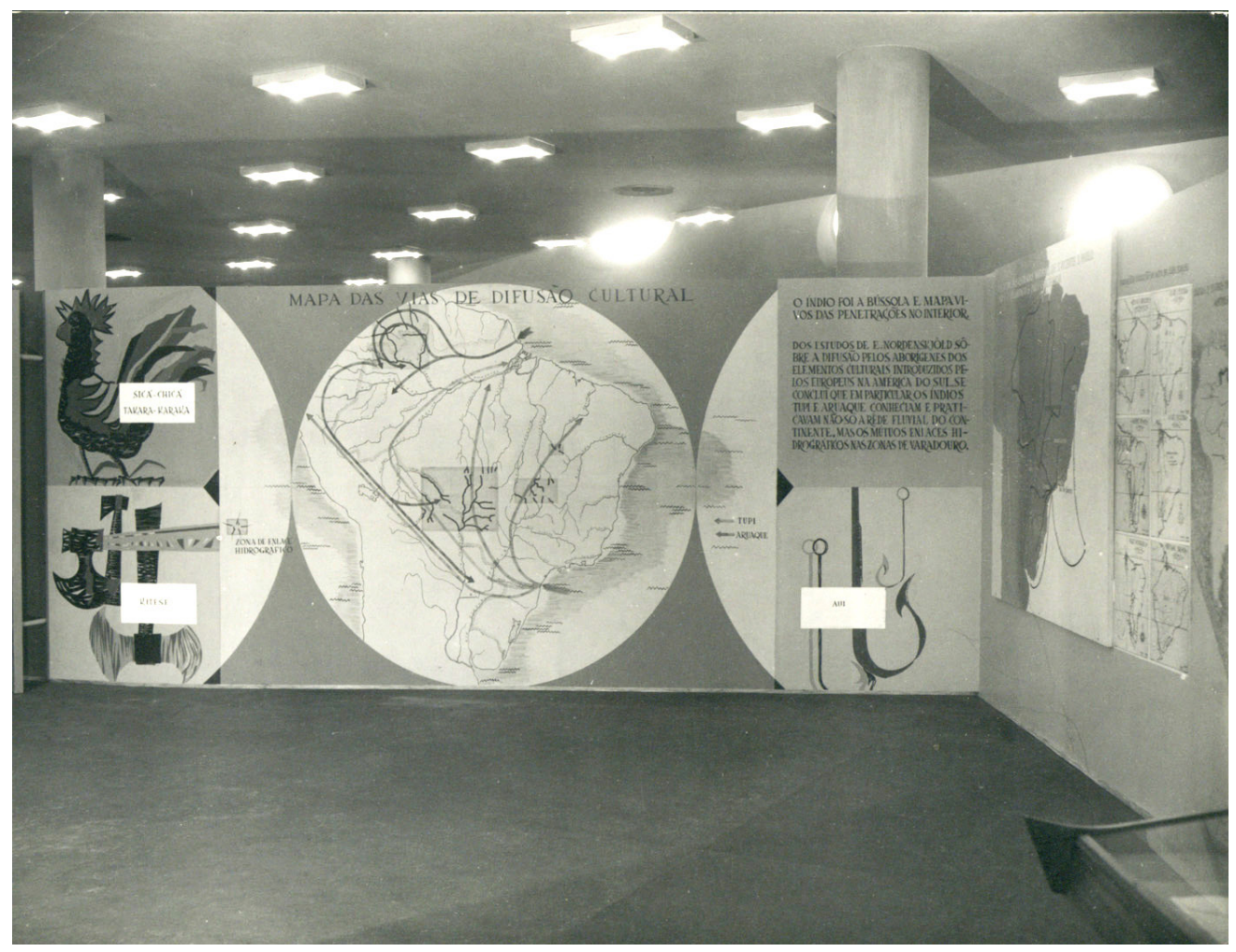

Figura 14 - Seção IV, mapa das vias (indígenas) de difusão cultural. Ary Duarte. São Paulo, s/d. Fonte: BNP/ACPC, E25/1506. Foto: Fotógrafo não identificado.

A fotografia que capturou o painel produzido a partir do trabalho do cartógrafo Ary Duarte (Figura 14) permite identificar à direita o painel seguinte, que trazia diversos mapas. $\bigcirc$ primeiro, em tamanho maior, era um Esquema das estradas naturais de São Vicente e São Paulo para o Attântico e para o interior. Ao centro do quadro, um conjunto de fotocópias "exemplifica a formação e evolução do mito da llha Brasil". Tratava-se dos mapas de Diogo Ribeiro (1523-1527), André Homem (1559), Vaz Dourado (1568), João Teixeira (1630/1642) e Nicolau Sanson (1658). Por fim, um mapa intitulado Faixas e centros formadores das fronteiras da América Meridional foi utilizado para apresentar os tão falados limites naturais que formariam a suposta unidade geográfica.

Em suma, os dois painéis montados lado a lado e suas diversas representações cartográficas, na sequência da abertura que aludia às matrizes portuguesas e indígenas das bandeiras, qualificava ao visitante quais seriam tais matrizes, comunicando as apreensões de nativos e de portugueses daquele vasto território. Dispostos dessa maneira, os mapas conduziam a uma leitura comparativa por meio das legendas apresentadas, sugerindo uma harmônica simbiose na 
formação de um território brasileiro. Para além disso, outra legenda ainda dava conta da "continuidade cultural, da linguagem náutica dos portugueses para a dos bandeirantes". Nesses termos, a expansão dos navegadores portugueses se transubstanciava nas incursões sertanejas, expressa também pelo uso de termos como "armar, armador e armação, navegar, descobrimento, roteiro, gerais, monções, ressaca, restinga", questão linguística apresentada por Cortesão em conferências e textos.

A cartografia histórica continuou a se destacar nas vitrines seguintes, como os Atlas dos Teixeiras, de meados do século XVII, cedidos pela Mapoteca do Itamaraty. Deles se destacava o que se chama de propaganda política dos tempos da Restauração de Portugal (1640), criticando o referido desleixo da Espanha e as ameaças holandesas do território sob administração portuguesa. Em seguida, destaques do mesmo conjunto documental, de 1666, foram expostos. Nos fólios figuravam regiões da costa vicentina; partes do mundo também eram apresentadas, dando conta das características das representações cartográficas seiscentistas.

Para demonstrar o "significado das bandeiras na história nacional", foram escolhidas, como se indica, frases de valor épico, dispostas em um painel: dos padres jesuítas Diogo Ferrer e Manuel da Fonseca, à menção das adversidades às quais se sujeitavam os bandeirantes, chamados pelo último de "conquistadores deste Novo Mundo"; de Oliveira Martins citando o dito "espírito aventureiro dos paulistas" como "a primeira alma da Nação Brasileira e São Paulo", local de origem do então "movimento de ocupação dos sertões"; de Euclides da Cunha, por sua vez, exibindo a opinião de que as entradas e sua "tradição heroica" seriam "o único aspecto original da nossa história".

A seguir, diversas armas de três séculos complementavam a epopeia, cedidas por instituições como os museus Histórico Nacional, do Ouro de Sabará e Paulista, assim como por particulares como Amoroso Neto. Desenhos de Wasth Rodrigues explicitavam o uso daqueles instrumentos e um diorama de Wladimir Douchkine apresentava "bandeirantes em marcha no sertão, acompanhados por índios, um deles vestindo a típica couraça de algodão". Dessa forma, com frases de efeito, armas e representações pictóricas, caracterizavam-se os heroicos bandeirantes.

Os documentos sobre os quais trabalhou Cortesão na Biblioteca Nacional brasileira eram acompanhados por duas cartas pertencentes a seu outro local de trabalho, a Mapoteca do Itamaraty, nas quais estava representada a região das missões da Província Jesuítica do Paraguai, cujos remanescentes encontram-se em parte do atual território brasileiro. Como fica manifesto em parte substancial das seções organizadas diretamente por Cortesão, as fontes e instituições em que 
trabalhava foram determinantes no percurso estabelecido da exposição. Outras instituições com as quais Cortesão manteve contato, como o Instituto Histórico e Geográfico Brasileiro também deram sua contribuição a essa seção, como os mapas históricos da América do Sul que compuseram a vitrine posterior.

Com dois metros e meio de altura por quase dezessete de comprimento, mais um mural de Manuel Lapa se fazia presente, dessa vez apresentando uma bandeira em marcha. Segundo a descrição do catálogo, a bandeira era representada desde o momento da partida, "rompendo a selva, descendo os rios, transpondo as corredeiras e, no último trecho, em luta com os Guaicuru, índios cavaleiros do Mato Grosso, que constituíram, com os Paiaguá, um dos maiores adversários à marcha dos paulistas". A legenda que apresenta o grande mural sustenta a representação, citando ainda a chegada ao Prata, aos Andes, à foz do Amazonas: "molda, dando-the vida própria e épica, o Brasil". Sintetizada em um mesmo mural, pela imagem e pela legenda, a marcha dos paulistas era monumentalmente celebrada, ao mesmo tempo em que identificava como seus inimigos aqueles índios que resistiram à presença bandeirante. $\bigcirc$ roteiro de Raposo Tavares, o mais extenso de todos, serviu de base para o mural e para a legenda que o comunicava.

Entre os documentos, originais ou fotocopiados sobre a época, havia também mapas produzidos especialmente para a exposição, como um da série que mostra o traçado aproximado da cidade de São Paulo e seus arredores em 1654, feito pela equipe coordenada por Gastão Bierrenbach de Lima. Além desse, outro do cartógrafo Ary Duarte apresentava o traçado das bandeiras de Antônio Raposo Tavares ao Guairá e ao Tape, a grande bandeira de 1648-1651, entre outras. De Afonso Taunay era a citação que acompanhava o esquema: "A mais prodigiosa jornada de devassa de terras ignotas em qualquer tempo e qualquer continente jamais ocorrida".

Sobre a presença holandesa no Brasil, pinturas de Frans Post emprestadas pelo Museu Nacional de Belas Artes e pelo Ministério das Relações Exteriores compuseram o painel dedicado às "mais altas expressões da civilização europeia" dos tempos de Maurício de Nassau. Essa presença também foi expressa por mapas holandeses de propriedade da Mapoteca do Itamaraty e do $I H G B$, acompanhados de um retrato do próprio Nassau.

A última vitrine reunia diversos documentos do Arquivo Histórico do Ultramar e da Biblioteca Nacional brasileira referentes à segunda metade do século XVII, tratando de assuntos de São Paulo, de outras vilas como Iguape e Paranaguá, do Paraguai e das bandeiras de Raposo Tavares. Finalizando a quarta seção, um 
painel indicava o assunto apresentado na seção seguinte: a mineração: depois da Restauração, o monarca D. João IV deu "novo e intenso calor à busca de minas na persuasão da existência de ouro no Brasil". Em 1642, assinalava o painel, um grupo de representantes paulistas foi a Lisboa pedir ao Rei a instalação de uma Casa da Moeda. Nesse sentido, a apresentação do bandeirismo se sustentava na exposição sobre duas finalidades principais: a expansão do território e a corrida do ouro. As duas seções seguintes, ainda sob a orientação direta de Cortesão, se aprofundariam sobre essas duas questões.

A quinta seção - A Capitania de São Paulo e a Expansão Mineradora - foi dedicada ao processo de alargamento do "quadro físico em que vai desenvolverse a história de São Paulo", conforme indica o texto de introdução do catálogo da exposição. Tal impulso, diz o texto, não só unificou o território e multiplicou o povoamento como também, a partir do afluxo de ouro e de poder, deu ao Brasil maior segurança, "pondo problemas que provocam uma renovação da cultura na metrópole". Ao longo desse segmento, narrou-se essencialmente o século XVIII e o processo que culminaria nos tratados que revogariam Tordesilhas.

Fernão Dias Pais, o cognominado governador das esmeraldas, foi o destaque de abertura da seção. Para Cortesão, Fernão Dias foi o "grande precursor" e a "mais isenta, heroica e dramática figura de bandeirante", abrindo o caminho para "a era das Minas Gerais". Talvez a maior das revelações da exposição, segundo seus organizadores, tenham sido os trinta mapas inéditos de bandeirantes e sertanistas encontrados. Até aquele momento, segundo afirmam, não se conheciam "no original, mapas típicos de bandeirantes e de sertanistas onde, sobre os traços rudes, sentíssemos como que sair do Caos uma nova e vasta entidade geográfica". Cortesão e seu grupo acreditam ter conseguido "apontar com segurança alguns desses mapas, dum traçado mais que rudimentar, mas revelando extraordinárias qualidades de orientação e expressão cartográfica, como sendo obra de bandeirantes". Desses, destacou-se o Mapa geral da região das Monções de São Paulo a Cuiabá, com indicações sumárias da viagem pelos rios e em estilo retilíneo como as cartas indígenas: tais características levam a atribuílo a um autor bandeirante paulista de cerca de 1720. $O$ documento foi considerado um dos grandes monumentos da exposição, de acordo com a introdução do catálogo.

As capitanias de Minas Gerais, Goiás e Mato Grosso, formadas a partir da primeira metade dos Setecentos, atestariam a grandiosidade das expedições em busca de ouro, movimento este que colocaria a metrópole na posição de buscar resolver os problemas de soberania frente a América espanhola e ao Tratado de Tordesilhas. $O$ monarca $D$. João $V$ e seus conselheiros promoveriam então, antes da Espanha, a renovação dos estudos astronômicos e cartográficos, enviando em 
1729 a Missão dos Padres Matemáticos que traçariam o Novo Atlas do Brasil, com o objetivo de fixar a situação do Meridiano de Tordesilhas por meio de longitudes observadas. Os trabalhos resultantes da missão, muitos dos quais se expuseram na quinta seção, "estabeleceram as bases científicas sobre as quais o genial paulista de Santos, Alexandre de Gusmão, virá a criar e negociar o Tratado de Madri". De tal modo, qualquer sentimento antilusitano que pudesse emergir da narrativa histórica sobre a extração do ouro não encontraria espaço, pois a mineração estaria justificada pela garantia da presente grandeza territorial brasileira.

No segmento da seção dedicado às monções, alguns documentos inéditos foram apresentados. O objetivo foi o de "tornar vivo o valor épico das jornadas monçoeiras e a importância que toma, nessa época, o Tietê com suas lendas". Também grande visibilidade teve a questão das disputas pela Colônia do Sacramento, cercada e assaltada por castelhanos de Buenos Aires e jesuítas missioneiros, o que se apontou como um importante evento no "processo histórico da formação territorial do Brasil".

Na seção, os documentos foram expostos no intuito de ilustrar o nascimento do sentimento de "pátria nova", fruto da expansão mineradora e dos sujeitos "enobrecidos pela ação épica" que criavam uma "consciência de grupo social" e reclamavam vantagens. Desse sentimento, não apenas dos paulistas envolvidos na mineração, se sobressai o sermão do padre Bartolomeu de Gusmão, de 1717. A criação da Capitania de São Paulo, bem como seu alargamento aos ałuais limites ocidentais do Brasil, a criação da Diocese Paulista, o esplendor do culto religioso e certas expressões religiosas e culturais típicas das regiões auríferas, foram também documentalmente representadas.

A ideia comunicada por meio de uma legenda no painel de abertura da seção reforçava o mote da exposição, sobre a dita unificação do território, além de ir ao encontro do ufanismo paulista que era respirado naquelas comemorações. Qualificando a expansão mineradora como paulista, o texto conferia a esses a liderança do impulso "que unificou o território e multiplicou o povoamento", dando ainda ao Brasil, "com o súbito afluxo do ouro e do poderio, a consciência mais segura de uma entidade econômica, social e políitica, capaz de governar-se a si própria". De tal modo, conduzia-se à interpretação segundo a qual o germe da autonomia brasileira seria fruto desse expansionismo paulista.

A profusão de peças expostas foi maior da quinta seção em diante, provavelmente por conta da progressiva aproximação temporal. Onze mapas setecentistas brasileiros foram expostos na primeira vitrine, pertencentes em sua 
maioria à Biblioteca Nacional do Rio de Janeiro. Entre eles, alguns esboços e borrões sertanistas cartografando sobretudo as regiões auríferas. Outros dezessete foram expostos nas vitrines seguintes, também na maior parte cedidos pela mesma instituição, representando em grande parte a região das monções de Porto Feliz a Cuiabá e outras áreas de mineração. Em outras duas vitrines foram expostos documentos notadamente oficiais que compunham um quadro das atividades econômicas, políticas e sociais relativas ao período, em sua maioria petições, cartas régias, contratos e correspondências relativos aos descobrimentos de minas e a questões como o cativeiro de índios na vila de São Paulo. Salomão de Vasconcelos, da equipe de colaboradores da exposição, recompôs o traçado da rota da bandeira de Fernão Dias Paes em busca de esmeraldas, indicando pousos, feitorias e arraiais deixados pela expedição. Dois desenhos de Fernando Lemos representavam uma paisagem mineira e a agonia de Fernão Dias no sertão.

Expunham-se ainda documentos relativos a regiões como a platina Colônia do Sacramento e outras partes da costa e do chamado sertão do Brasil, como um mapa provavelmente de 1704 de "excepcional valor para o estudo dos caminhos de penetração de São Paulo em direção às minas e a localização dos primeiros achados da região dos Cataguases". Além disso, os ataques franceses ao Rio de Janeiro não ficaram alheios à narrativa, salientando-se dos mapas referentes a esses eventos os parcos conhecimentos geográficos que eles tinham dessa parte da América do Sul, indiretamente em comparação a brasileiros e portugueses.

Do Museu Paulista, fez parte da mostra uma arca de madeira de 1738, que serviu de cofre a Clemente Cotrim, "juiz de órfãos trienal nesta cidade [de São Paulo]", cujo nome, profissão e finalidade do objeto aparecem inscritos junto das armas de D. João V. O Museu do Ouro de Sabará, que cedeu diversas peças à exposição, teve figurando nessa parte da seção um almofariz utilizado em mineração.

Um mural de Clóvis Graciano, artista que ilustrou o livro de Ernani Silva Bruno lançado sob o selo oficial das comemorações do quarto centenário de São Paulo, 60 representava a atividade mineradora em um rio de montanha. De acordo com o catálogo, junto à obra foram expostos objetos utilizados na lida do ouro, emprestados pelo museu sabaraense. A figuração dos homens portugueses ou lusobrasileiros é a única em que se distingue a fisionomia do rosto, assim como são os únicos elementos humanos a portar vestimentas. Os mineradores parecem nus ou seminus, sem o rosto delineado - o oposto dos homens brancos, vestidos e com o rosto definido -, sugerindo uma leitura em que se salienta a diferença entre os sujeitos representados e a condição compartilhada pelos que trabalham, perspectiva bastante recorrente em suas obras, preocupadas com as questões sociais. 
Após a apresentação da Missão dos Padres Matemáticos, as monções foram retratadas por uma maquete produzida pelos artistas da exposição, esquematizando a chamada estrada fluvial entre Porto Feliz e Cuiabá. Em seguida, dois desenhos de Fernando Lemos reproduziam um aspecto urbano de Cuiabá e uma paisagem do rio Tietê, vista do alto do embarcadouro de Porto Feliz. Do rio que corta São Paulo até desaguar no rio Paraná, um painel apresentava suas lendas e prodígios, contados num mural de Arcindo Madeira, remetendo a figuras como Anchieta e Frei Galvão, canoas fantasmas, laras e cobras gigantes.

A Prefeitura de Porto Feliz cedeu à exposição um batelão das monções, escavado em um só tronco e medindo pouco mais de nove metros de comprimento. Na legenda sobre a embarcação dava-se tom épico às expedições, comparando seus perigos aos que eram corridos pelos navegantes das viagens entre Lisboa e a Índia: novamente induzia-se à comparação entre o expansionismo marítimo português e o fluvial/terrestre pelos caminhos sul-americanos. Catorze mapas e documentos foram dispostos em duas vitrines dedicadas a Goiás e ao Mato Grosso e às incursões feitas para aquelas regiões ao longo do século XVIII, entre eles um mapa produzido por Ary Duarte para a exposição demonstrando as Bandeiras de ligação entre o Prata e o Amazonas, lideradas por Manoel Feliz de Lima (1742) e João de Souza Azevedo (1747).

Para apresentar os documentos da região das Minas Gerais, expôs-se um quadro de madeira entalhada em baixo-relevo do "barroco primitivo" cedido pelo Museu do Ouro de Sabará. A peça fazia parte, segundo consta, da lgreja Matriz daquela cidade mineira. Dos documentos expostos na vitrine, figuravam o Livro dos termos do Governo de Minas, da administração da Capitania de São Paulo e Minas de Ouro, criada por Carta Régia de 1709, e a Carta Real de 24 de junho de 171 1, que elevou a vila de São Paulo à categoria de cidade.

A chamada renovação da cultura em Portugal, operada durante os reinados de D. João V, D. José l e D. Maria I, graças aos estrangeirados - os portugueses que se formavam em outros países - permitiu à metrópole, segundo a legenda do painel destinado a comunicar aquele fenômeno, "dirigir com eficácia a definição e defesa dos justos limites do Brasil", dando "de novo a São Paulo um lugar proeminente nessa fase da história do Brasil". A questão da formação dos limites foi inserida no quadro das transformações ocorridas em Portugal nos tempos dessa renovação cultural. A partir de uma gravura de Debrie de 1742, representando as "quatro partes do mundo" e homenageando D. João $V$, a renovação que se dava nas culturas geográfica, astronômica e cartográfica era celebrada, demonstrando-se então que as novas ideias, sobretudo as vindas da França e da Inglaterra, "refletiram-se em Portugal por vários modos", entre eles a criação das academias e o desenvolvimento 
da diplomacia, figurando Alexandre de Gusmão em uma lista de homens encarregados de tratar da "defesa dos limites portugueses na América do Sul".

Caminhando para o final do percurso da quinta seção, um painel trazia um grande mapa denominado Esquema geral das bandeiras paulistas, feito especialmente para a exposição por Fukugawa Akira sob orientação de Jaime Cortesão. Em cores diferentes, assinalavam-se no mapa os traçados das bandeiras em cada século. Na sucessão, fotocópias de mapas hidrográficos do Serviço Geográfico do Exército Brasileiro apresentavam a costa da capitania de São Paulo com instruções minuciosas para sua navegação. Tratava-se de mapas-roteiros que evidenciavam o crescimento da navegação entre o Rio de Janeiro e Santos, bem como entre esses e os portos do Sul até o Prata. Ainda nesse painel, um novo mapa da série executada pela equipe do engenheiro Gastão César Bierrenbach de Lima mostrava o traçado aproximado de São Paulo e arredores em 1754, na metade do percurso quadricentenário.

Na conclusão da seção deu-se relevo às festividades e ao culto católico em São Paulo em meados do XVIII, assim como se apresentou um exemplar original, emprestado pelo Arquivo Nacional da Torre do Tombo, da bula papal Candor Lucis Aeternae. $O$ documento de fins de 1745 erigia os bispados de Mariana e de São Paulo e as prelazias de Goiás e Cuiabá. Diversas imagens religiosas cedidas pelo Museu da Cúria Metropolitana de São Paulo e pelo Museu Paulista participaram da representação plástica da vida religiosa setecentista.

O painel de encerramento da seção foi um mural de Tarsila do Amaral (Figura 15) que representa uma procissão de Corpus Christi na São Paulo de meados dos Setecentos, próximo de uma imagem de São Jorge em madeira, desmontável, que era conduzida a cavalo nessas ocasiões. O cavalo com a representação do santo montada sobre ele figura no mural da artista modernista, no qual são também identificáveis as coloniais igrejas da Sé e de São Pedro, ambas no antigo Largo da Sé. Próximas às crianças vestidas de anjos, à direita da imagem, figuram uma mulher e duas crianças negras, aparentemente assistindo ao cortejo composto por homens de azul a trazer o cavalo, que segue à frente do padre com o ostensório, sob o pálio sustentado por um outro grupo.

Uma vitrine, enfim, expunha cinco aquarelas originais do século XVIII, de um artista português não identificado. Nelas, "danças negras de congada" estavam registradas, cerimônias estas descritas como aquelas "em que os negros e as negras fundem ritos católicos e ritmos africanos". Apesar de terem sido algumas das mais frequentes manifestações religiosas e culturais das regiões de mineração - e de ainda serem celebradas tanto à época da exposição como em nossos dias -, apenas cinco pequenas aquarelas faziam-nas presentes na grandiosa exposição. 


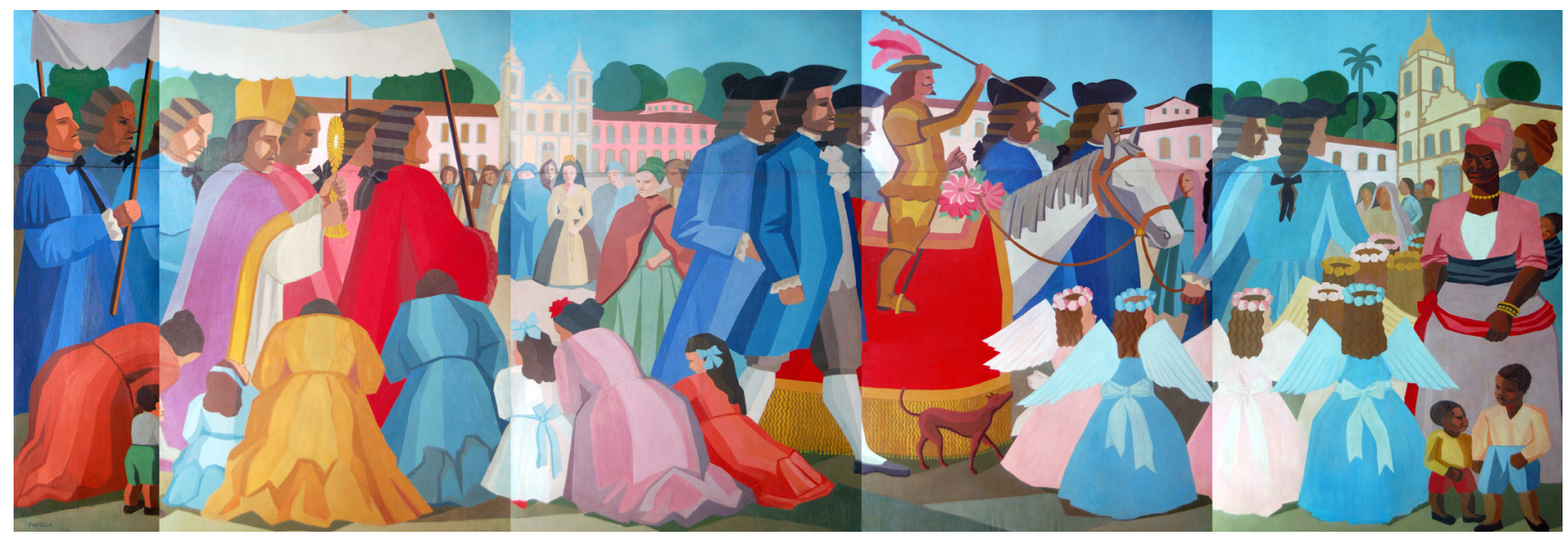

Figura 15 - Procissão de Corpus Christi. Mural de Tarsila do Amaral $(700 \times 250$ cm). Fonte: Acervo da Coleção de Arte da Cidade/Centro Cultural São Paulo. Foto: Emilio Carlos Jeronymo Dantas.

A sexta seção - São Paulo e a formação dos limites do Brasil - a última organizada diretamente por Jaime Cortesão, desempenhou o papel de corolário da narrativa das teses do historiador português. No texto introdutório do catálogo, ela é descrita como referente às "consequências do bandeirismo nas relações políticas entre Portugal e a Espanha e das suas profundas repercussões na Metrópole e na América". Como representativo desse momento, Cortesão escolheu o engenheiro-mor Manoel de Azevedo Fortes, inspirador da renovação do ensino da engenharia militar portuguesa, que ensejou por sua vez a formação de uma diversidade de engenheiros e cartógrafos que viriam a ser importantes tanto na definição quanto na defesa dos limites do Brasil. Ao engenheiro-mor do Reino e ao Secretário de Estado Diogo de Mendonça Corte Real foi dedicado o painel de abertura da seção.

Ao que indica o catálogo, a intenção de Cortesão em sua última seção foi conferir grande relevo ao "verdadeiro homem representativo" que foi Alexandre de Gusmão e a seu feito, o Tratado de Madri. Mapas portugueses e estrangeiros comporiam os antecedentes daquele acordo e explicariam os esforços do diplomata para a execução do Tratado que revogava o de Tordesilhas, lançando mão das inovações científicas e jurídicas de seu tempo. De acordo com o texto, a centralidade que a exposição conferia ao Tratado de Madri the dava o sentido de "sanção jurídica à expansão paulista", recorrendo ao espírito de fronteira - a "consciência dos limites necessários, justos e invioláveis", conceito cunhado pelo geógrafo Vidal de La Blache que seria necessário à formação dos Estados. Nesse sentido, o Mapa das Cortes ganha foros de monumento cartográfico na exposição, figurando de diversas formas para comunicar diversas leituras. 
Segundo Cortesão, o fenômeno do bandeirismo dirigido, que a partir da segunda metade dos Setecentos transformaria o bandeirismo livre, estava "enquadrado nas atividades gerais do Estado, e tornado científico graças à renovação da cultura em Portugal, de que tantos e tão ilustres paulistas [...] partilharam". Dessa forma, apesar de reconhecer a liderança e a iniciativa paulistas, o historiador conferia maiores consequências às ações referentes ao território coordenadas pela Coroa, como se o Estado português tivesse seguido pelas veredas abertas pelos bandeirantes. Cortesão qualifica como grande agente de transformação desse novo impulso o Morgado de Mateus, à testa da Capitania de São Paulo restaurada em 1765: o novo incumbente teria sabido, segundo o citado Machado de Oliveira, "ressuscitar nos paulistas o prurido das lides nas matas de que apenas tinham leves recordações". Acrescentou Cortesão que, embora a frase estivesse longe de corresponder à verdade, seria lícito caracterizar tal tendência como um novo impulso do bandeirismo, "sistematicamente dirigido, sob disciplina militar, para objetivos de reivindicação territorial, ou quando transformado em expedição científica".

Junto do painel de abertura, oito mapas setecentistas de várias regiões do Brasil expuseram o quadro dos conhecimentos geográficos sobre o continente sulamericano à época do Tratado de Madri. Entre esses mapas estava o de Francisco Tosi Colombina, de 1751, mostrando a comunicação entre as bacias do Prata e do Amazonas, documento amplamente utilizado nos estudos de Cortesão para o debate sobre a construção da nova capital do Brasil, ainda durante o Estado Novo brasileiro.

Alexandre de Gusmão e o Tratado de Madri, sujeito e assunto sobre os quais Cortesão dedicava muitos de seus estudos há anos, eram o tema das vitrines e painéis registrados em fotografia (Figura 16). Seguindo a sequência registrada no catálogo, a primeira vitrine trazia dois volumes da obra-prima de Cortesão, Alexandre de Gusmão e o Tratado de Madrid, bem como fotocópias da assinatura do diplomata e de documentos por ele produzidos ou a ele pertencentes. Ao lado da vitrine, o retrato de D. Luiz da Cunha, embaixador que representou Portugal em vários países, era acompanhado de sua identificação como "mestre e precursor de Alexandre de Gusmão". Assim como na seção anterior, tornaram-se frequentes no catálogo comentários sobre objetos expostos que extrapolam as legendas, demonstrando a familiaridade entre Cortesão e aquelas que foram também as fontes de suas pesquisas.

O painel que ocupa o centro da imagem era composto por um mural de João Maria dos Santos representando a assinatura do Tratado de Madri, produzido de modo a figurar como se tivesse ao fundo o Mapa das Cortes. O mapa foi sobreposto a um do Brasil contemporâneo, concorrendo assim tanto para a comparação entre ambos os contornos quanto para referendar as teses apresentadas 


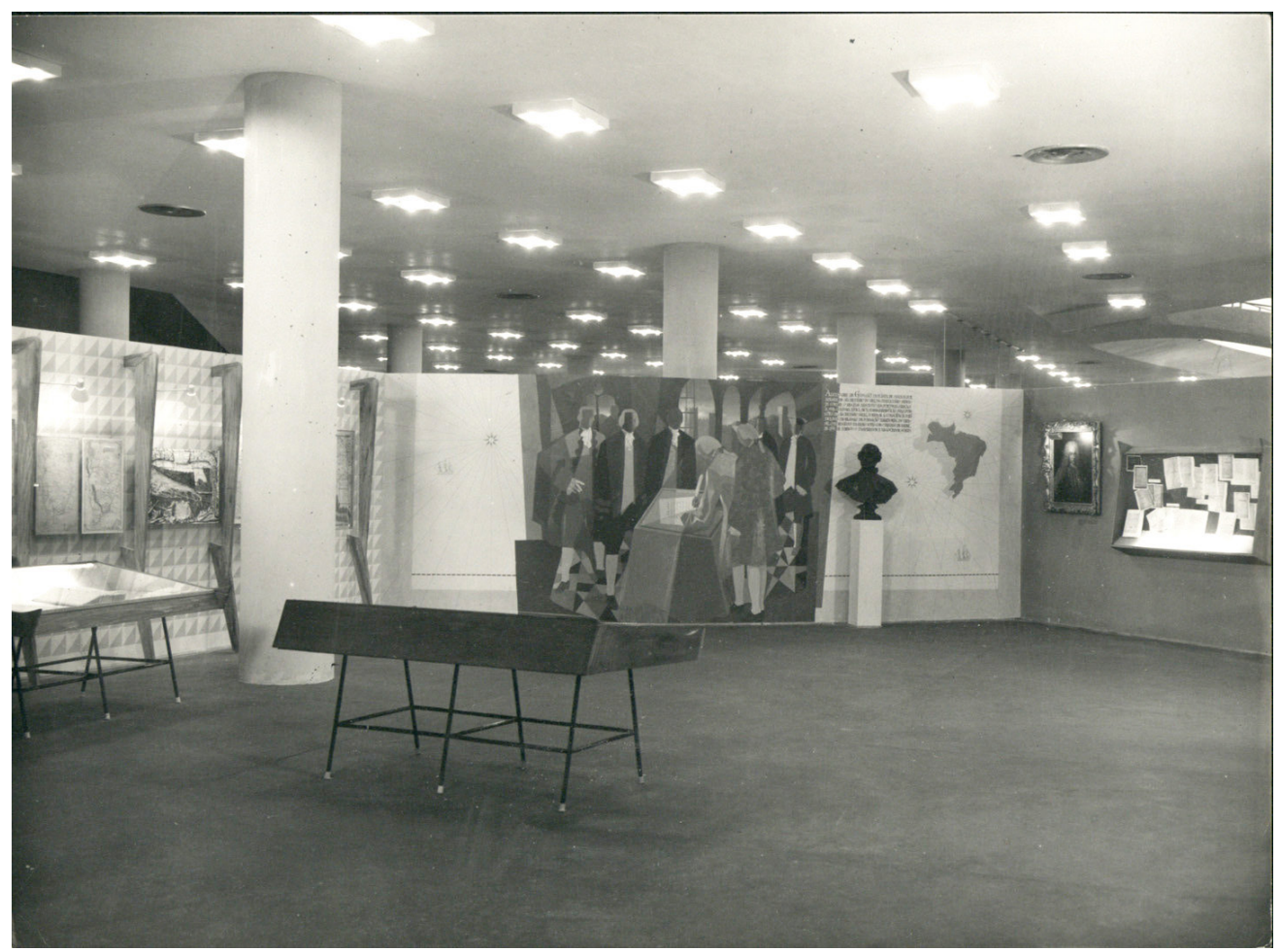

Figura 16 - Seção VI, busto de Alexandre de Gusmão e painel sobre assinatura do Tratado de Madri (1750). São Paulo, s/d. Fonte: BNP/ACPC, E25/1508. Foto: Fotógrafo não identificado.

até então do delineamento das fronteiras brasileiras pelos paulistas, sejam eles bandeirantes ou diplomatas. Logo acima do busto de Alexandre de Gusmão, emprestado pelo Ministério das Relações Exteriores, uma legenda inscrita sobre o mural e sobre a parte em que estava o mapa celebrava o diplomata: apesar de secretário real, Gusmão tinha sido "um panfletário ardente contra o regime absoluto de Portugal". Além disso, assinalava-se que devido a sua "cultura típica de 'estrangeirado', e às suas funções de secretário real, torna-se a consciência política dos problemas da formação territorial do Brasil, que resolveu em bases novas com o Tratado de Madrid, de que foi o inspirador e negociador oculto".

Na sequência, também compreendida na imagem, apresentaram-se documentos relativos ao Tratado de 1750, sobretudo cartográficos, que demonstravam o cumprimento dos termos do acordo, tais como as expedições para fixar as demarcações das fronteiras. Cópias do Tratado, exemplares do Mapa das Cortes, desenhos das regiões limítrofes entre as terras portuguesas e espanholas, entre outros documentos similares estavam provavelmente contidos em outras duas vitrines que compõem a fotografia. Esta imagem pode, portanto, ter enquadrado toda a parte da exposição diretamente referente a Alexandre de Gusmão e ao 
Tratado de Madri. Parte essa, de acordo com a concepção de Cortesão, que encerraria o sentido maior da ação paulista para definir os limites do Brasil.

O quadro da renovação cultural portuguesa era complementado com a exibição de um retrato do Marquês de Pombal, do século XVIII, também emprestado pelo ltamaraty. A legenda que acompanhava o retrato de Sebastião José Carvalho e Melo, o Secretário do Reino de D. José I, salientava algumas das ações motivadas por sua influência e pelas chamadas ideias novas, como a abolição da Companhia de Jesus, a reforma da Universidade de Coimbra, o fim da escravidão na metrópole e a subordinação das sentenças da Inquisição à confirmação régia. Dessa forma, sua personalidade era lembrada no percurso sem concorrer com o protagonismo de Alexandre de Gusmão ou de outros homens do tempo da dita renovação cultural.

Prosseguindo com a exibição de peças brasileiras caracterizando a vida setecentista na colônia, expuseram-se quinze aquarelas de um artista português não identificado representando tipos e costumes brasileiros. Do cotidiano também foi exposto um cofre de ferro da Provedoria de São Paulo, pertencente ao Museu Paulista. Ainda nesse sentido, mapas e vistas da região da cidade de São Paulo, bem como de São Vicente, Curitiba, entre outras cedidas pelos Arquivo Histórico e Mapoteca do Itamaraty, se fizeram presentes.

Para dar relevo à administração do Morgado de Mateus, um painel buscou apreender a região sob seu governo. Para tanto, além de uma ampliação colorida de uma vista de Santos àquela época, o artista Wasth Rodrigues fez seis aquarelas especialmente para a mostra, representando os figurinos militares em uso na Capitania (séries semelhantes relacionadas a outras épocas foram apresentadas nas seções seguintes). Uma legenda fazia compreender que a restauração da Capitania de São Paulo, depois do período em que foi dissolvida e posta sob a administração do Rio de Janeiro, teria acontecido principalmente para atender à necessidade de "ocupar e defender as fronteiras meridionais do Brasil". Uma lacuna, no entanto, não permitia ao visitante compreender o motivo da dissolução e do posterior restabelecimento da Capitania.

Segundo se comunicou, o governador Luiz Antônio de Souza Botelho Mourão, - Morgado de Mateus, além de ter reavivado as bandeiras, promoveu o "redescobrimento dos sertões do Tibagi, dos rios Ivaí, Iguaçu, e campos de Guarapuava". Um diorama feito por Wladimir Douchkine representava o governador instruindo os novos regimentos paulistas no exercício das armas, tendo ao fundo a cidade de São Paulo conforme o desenho ampliado no painel seguinte, de cerca de 1770 , do original presente em um arquivo particular português. Documentos referentes às ações do governante foram apresentadas em uma vitrine, perto de onde também se via um retrato seu a óleo pertencente ao Conde de Mangualde, seu descendente. 
Trinta e um documentos, majoritariamente cartográficos, sobre as monções, o sul da América Portuguesa, a fortaleza de Nossa Senhora dos Prazeres do Iguatemi, entre outros lugares, foram dispostos em quatro vitrines e um painel. Das informações oferecidas pelas legendas desses documentos, uma citava a motivação da fundação da fortaleza de lguatemi, de "consolidar e estender a soberania portuguesa nos territórios ocidentais". A fortaleza, em região hoje correspondente ao estado do Mato Grosso do Sul, teria sido, segundo apresentava o texto, "glória e sorvedouro de vidas paulistas". Além disso, expôs-se então sobre a Expedição filosófica, composta por uma "plêiade muito notável de cientistas brasileiros" que "concorreu para dar configuração científica aos traços gerais da geografia do Brasil".

Caminhando para fins do Setecentos, a documentação sobre as regiões das minas e fronteiriças apresentou o novo tratado de limites de Santo Ildefonso (1777). A execução de tal acordo traria "o último surto do bandeirismo paulista", dessa vez "dirigido e com caráter científico". Uma vitrine com diversos mapas e documentos relativos às expedições do paulista Francisco José de Lacerda e Almeida, um dos executores do Tratado, conduziam à interpretação de que as bases das expedições em terras da América Portuguesa abriram caminho para explorações em outras paragens sul-americanas e africanas, notadamente nos rios de Sena, atual Moçambique. Lacerda e Almeida era identificado como astrônomo e naturalista: o "bandeirante tornado homem de ciência" era o autor do "traçado científico [...] da estrada das Monções", exposta parcialmente em um painel.

Além dos mapas, apresentaram-se também desenhos de animais, armas, instrumentos musicais e mecânicos, ornatos, utensílios domésticos, bem como dos índios produtores desses objetos. Outros apresentavam também a forma de construção de canoas e as habitações da região amazônica. $\bigcirc$ mural de Artur Jorge apresentava, junto desses documentos, a Expedição filosófica dirigida por Alexandre Rodrigues Ferreira, o Humboldt brasileiro, na bacia amazônica. Essa parte da exposição, retratada na fotografia capturada no dia de sua inauguração solene (Figura 17), demonstrava que no quadro da história do Brasil eram muitas as permanências da ação das bandeiras, das monções, das expedições filosóficas e mesmo da expansão marítima portuguesa.

A seção foi concluída com um conjunto de mapas de Silva Pontes e José Fernandes Portugal, "o maior hidrógrafo de seu tempo". Entre esses mapas, um do Atlântico e um do Índico, com direção de ventos e correntes de acordo com a época, foram salientados como precursores dos mapas de navegação que depois se tornariam fundamentais. Além disso, o caminho para o século XIX era aberto por um painel com as missões científicas e artísticas do tempo de D. João VI. Encerrava- 


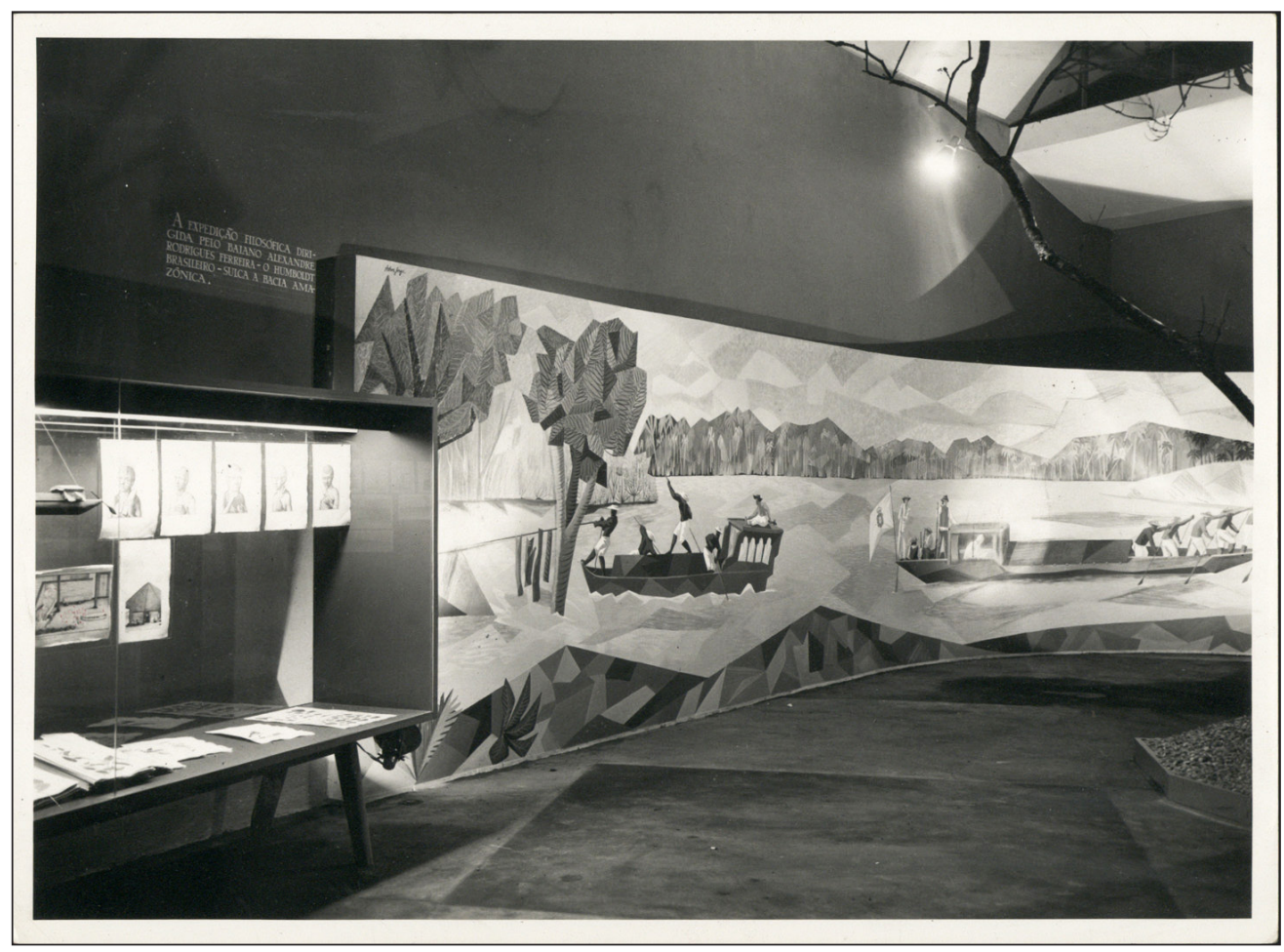

Figura 17 - Seção VI, mural de Artur Jorge (1075 × 250 cm) sobre a "Expedição Filosófica" de Alexandre Rodrigues Ferreira. São Paulo, 13 set. 1954. Fonte: BNP/ACPC, E25/1509. Foto: Bernardelli.

se assim a seção, com uma referência ao esplendor da Corte portuguesa proporcionado pelo ouro brasileiro.

As três seções finais, organizadas por Ernani Silva Bruno, Hélio Damante e Mário Neme, não foram ancoradas em temas como as seis anteriores. Seu recorte foi político-administrativo, dedicado a apresentar as relações entre São Paulo e a independência, o Império e a República, tendo como marco inicial o ano de 1765 e a restauração da autonomia paulista em relação à capitania do Rio de Janeiro. A primeira das três se empenhou em narrar o prelúdio da independência do Brasil, relevando o desenvolvimento de uma economia e cultura locais, apontando ainda para as condições da colônia antes e depois da instalação da Corte no Rio de Janeiro em 1808 e o papel de legionários paulistas no guarnecimento das fronteiras do Sul.

Dois mapas apresentavam na sétima seção a ocupação do território paulista: o primeiro, de 1792, foi levantado a pedido do Bernardo José de Lorena, governador, e o outro foi feito especialmente para a exposição pela equipe de Luís Saia. Nélson Nóbrega pintou um painel a pedido dos organizadores da exposição, 
com os elementos relevantes da economia paulista da época, como os muares de Sorocaba e os engenhos de açúcar. Acompanham também reproduções de telas do padre Jesuíno do Monte Carmelo, o manuscrito original de Pedro Taques e um exemplar da primeira edição de Frei Gaspar da Madre de Deus, além de documentos sobre as aulas régias. Tais elementos buscaram dar conta da situação das letras e das artes na capitania.

Da chegada da Família Real, expôs-se o documento original que abriu os portos brasileiros ao comércio internacional em 1808. Os retratos de D. Maria l e de D. João VI, ambos do Museu Paulista, bem como um aspecto do Largo do Paço pintado pelos artistas da exposição inspirado no original de Debret, foram acompanhados por objetos emprestados pelo Museu Imperial de Petrópolis e por algumas das muito anunciadas aquarelas de Thomas Ender (1817), "remetidas da Áustria expressamente para a Exposição". Além disso, na esteira da instalação da Corte, expuseram-se menções e objetos referentes à missão artística francesa, à imprensa régia, à criação do Jardim Botânico, à Biblioteca Real e ao Museu de Ciências Naturais.

O segundo segmento da seção apresentava o aumento da produção açucareira e a introdução da cafeicultura no Vale do Paraíba, região apresentada pelas aquarelas de Ender e pelas reproduções a partir de Debret, além da Real Fábrica de Ferro nas cercanias de Sorocaba. Tal transformação era, de acordo com a narrativa da exposição, inserida no quadro dos reflexos das medidas da Corte instalada no Rio de Janeiro. Assim como no novo mapa executado pela equipe de Luís Saia a mostrar a expansão do povoamento paulista, ora na década de 1810 a 1819, pululavam documentos textuais e iconográficos registrando a fundação de novas vilas, cidades e comarcas, muitos deles pertencentes a coleções particulares, entre elas as de Yan de Almeida Prado e Benedito Peretto. $\bigcirc$ ano de 1810 mereceu da organização da exposição um painel especial: naquele ano, a cidade de São Paulo recebia uma filial do Banco do Brasil, erguia o chafariz do Piques e o obelisco da Memória, considerado o primeiro monumento da capital. Também naquela data, o capitão de engenhos Rufino José Felizardo e Costa fazia levantar a primeira planta da cidade, exibida em fotografia ao lado de diversas vistas da cidade aquareladas também por Ender.

A finalização da seção, como não poderia deixar de ser, dizia respeito à própria Proclamação da Independência, apresentada por meio de retratos, gravuras e documentos manuscritos e impressos. Inicialmente, um panorama da cidade de São Paulo pintado pelos artistas da exposição a partir de uma aquarela de Pallière, da coleção de Yan de Almeida Prado, era acompanhado de uma legenda que comunicava o crescimento das tensões entre brasileiros e reinóis, a propaganda 
de ideias autonomistas e liberais, o retorno da Família Real e a intimação para o retorno de D. Pedro. Os homens políticos da Independência foram dispostos em um painel, com retratos originais cedidos pelo Museu Paulista e reproduções dos que se encontravam no acervo da mesma instituição.

Na vitrine que encerrava documentos referentes aos eventos transcorridos entre junho e setembro de 1822, registrava-se na exposição uma fala de D. Pedro I - um trecho da primeira após a Proclamação, dirigida à Câmara de São Paulo - que atestaria a relevância dos paulistas na campanha de autonomização do Brasil. Transcrita no texto de introdução do catálogo, a fala designava a Província de São Paulo como o ponto em que a Independência havia acontecido, antes de qualquer outra parte. Ainda que se refira ao lócus da Proclamação, no sítio histórico do Ipiranga, a interpretação da exposição conduz para o entendimento de que foi aquela terra que fez o Brasil independente. Dessa forma, as próprias palavras de D. Pedro eram mobilizadas para celebrar a história local, na exposição preocupada, em seu sentido amplo, em afirmar o papel paulista na construção da história nacional, seguindo a tendência inaugurada pelo guardião da história paulista, o Instituto Histórico e Geográfico de São Paulo, segundo o qual a história de São Paulo seria a própria história do Brasil. ${ }^{61}$

Hinos, objetos pertencentes a pessoas presentes na comitiva de D. Pedro, a Carta Régia de reconhecimento da Independência do Brasil, bem como uma reprodução de Independência ou Morte de Pedro Américo e um padrão da primeira bandeira imperial pertencentes ao Museu Paulista, foram apresentados em um painel e uma vitrine. Uma liteira e dezesseis aquarelas de Pallière e Ender encerravam a seção dando conta de cenas do cotidiano escravista, questão essa praticamente silenciada ao longo de toda a mostra.

Exibindo o Brasil monárquico, a oitava seção - São Paulo no Império buscou enfatizar, assim como na anterior, o papel paulista na política, na economia e na vida social do Império. A seção era uma das maiores da exposição e destacou o período em que a então província ampliou suas atividades econômicas e quando foi instalada a Academia de Direito (1828). Além disso, relevou-se na narrativa a oposição ao absolutismo de D. Pedro e o papel do padre paulista Diogo Feijó durante as Regências, bem como as iniciativas dos governos locais.

Mapas, reproduções fotográficas e pinturas apresentavam a cidade de então. Para expor a situação econômica da província durante aquele tempo, os painéis da seção mostravam "o aperfeiçoamento dos engenhos de açúcar", demonstrados por uma moenda de ferro, produto da fábrica de São João de Ipanema, do acervo do Museu Paulista, além do crescimento "notável" das lavouras de café, inicialmente no Vale do Paraíba, ora ilustradas com uma maquete da
61. A esse respeito, cf. Ferreira (2002) e Schwarcz (1993). 
fazenda Pau d'Alho, de São José do Barreiro, executada pela equipe de Luís Saia. Quanto às letras, às artes e ao ensino, a Academia de Direito, os primeiros jornais, os primeiros livros editados na cidade, a primeira Biblioteca Pública, o Gabinete Topográfico, assim como as aquarelas de Miguel Dutra, do Museu Paulista, eram apresentados como expressões das transformações da cidade nesse sentido.

Do Segundo Reinado, entre os eventos eleitos como marcantes, notabilizaram-se a Revolução Liberal de 1842 e a chamada Guerra do Paraguai, ambas com painéis e vitrines dedicados a elas. Segundo a legenda, a guerra declarada contra a República Paraguaia era uma reação aos "atos de hostilidade do ditador Solano Lopez". Quanto à questão da escravidão de africanos e afrodescendentes, aos quais pouco espaço se dedicou nas seções anteriores, foram apresentados "peças e documentos relativos às condições de vida e trabalho do escravo negro no Brasil". Entre eles, os diversos instrumentos punitivos e uma ampliação fotográfica de Negros no eito (1885), de Marc Ferrez, dividiam o espaço com os registros das "etapas da campanha abolicionista, em que São Paulo teve papel destacado, desde a atuação de Rui Barbosa, Luís Gama, Castro Alves e do jornal $O$ Radical Paulistano, até a fundação do Centro Abolicionista, em 1882", de onde se projetaram novos líderes como José Bonifácio, o Moço, e Antônio Bento, líder do movimento dos caifazes, vinculado às irmandades de pretos e pardos. Figuravam na exposição numerosos documentos relativos à instituição da escravidão, desde contratos de venda, autos de inquéritos policiais contra escravizados a exemplares de jornais que se bateram contra o cativeiro e a fotocópia do original da Lei Áurea. Retratos de Luís Gama, Antônio Bento, José do Patrocínio e da Princesa Isabel também compunham a apresentação do tema.

movimento republicano, também para marcar a projeção paulista no quadro da história nacional, teve sua narrativa aberta por um painel com ampliações fotográficas de retratos de lideranças republicanas paulistas. A legenda citava a criação do Partido Republicano no Rio de Janeiro em 1870 e a Convenção de ltu em abril de 1873. Segundo o texto introdutório, os ideais liberais em voga naquele tempo em muito condiziam com o programa republicano então apresentado. Uma vitrine foi dedicada à Convenção, apresentando documentos como os Livros de Atas e de Presença.

No que dizia respeito a São Paulo, o Reinado de Pedro II foi lembrado especialmente pelas ferrovias e pela imigração europeia, quando "consolidam-se os fundamentos do progresso contemporâneo de São Paulo". A legenda que sintetizava o período destacava as transformações da capital da província "no seu aspecto urbano, tornando-se ao mesmo tempo importante centro artístico, científico 
e literário". Do mesmo período, na sequência, um painel trazia uma galeria com governantes e bispos paulistas, citando ainda o incremento de um milhão de habitantes em um século, apesar do desmembramento da província do Paraná em 1853. Cinco mapas executados pela equipe de Luís Saia apresentavam a marcha do povoamento do território paulista a cada década. Ainda nesse sentido, um painel se aprofundava sobre a chamada conquista do oeste do território paulista, dando especial relevo ao café e às ferrovias. Um mural de Di Cavalcanti evocava então diversos aspectos de uma fazenda da época. As ferrovias e os "esforços de alguns homens de São Paulo no sentido de atrair para a sua província trabalhadores europeus, visando a substituição do trabalho servil pelo trabalho livre" corporificavam o inconteste progresso econômico provincial.

A última seção da exposição - São Paulo na República - teve como ponto de partida o ano da instauração do novo regime. De acordo com o texto introdutório do catálogo e com o texto do painel de abertura, o advento republicano foi considerado "etapa necessária do desenvolvimento políitico, econômico e social do país, desde a sua independência". Ainda nesse sentido, a mudança seguia a mesma tendência que introduzia novas modalidades de produção de riqueza, a partir da mecanização e da introdução de imigrantes "dotados de tradição industrial", associando assim, tacitamente, a monarquia ao escravismo. A ampliação do comércio exterior e o crescimento da urbanização, complementando o quadro, teriam impacto sobre as condições de vida e de trabalho. A seção saudaria ainda a descentralização promovida pelo modelo federalista, pelo qual haviam se batido as lideranças políticas paulistas.

Conforme se ressalta no texto-síntese sobre a seção, a ascendência paulista sobre o processo de transição de regime daria aos republicanos de São Paulo "a maior soma de responsabilidade na obra de estruturação e consolidação do regime, bem como na orientação política e administrativa do país". Ao demarcar o ponto de vista estruturante da seção final da exposição, é notável o esforço para justificar o domínio das oligarquias paulistas durante os primeiros tempos da República. Em suma, rememoradas as ações dos "estadistas de São Paulo à frente do governo da República", a exposição mostraria, de acordo com o catálogo, "que os paulistas desempenharam satisfatoriamente essa alta missão e que, dentro das limitações impostas por fatores adversos, contribuíram de maneira decisiva para o progresso do Brasil". Nesse sentido, encerrando a exposição, o ato final permitiria ao visitante que percorresse os sete mil metros quadrados da Oca uma visão de conjunto da história de São Paulo como a base que teria permitido a construção do país, vinculando símbolos de grandeza do passado e do presente como fragmentos de um mesmo percurso. 
Diferentemente das questões apresentadas como nacionais, encerradas na exposição de 1906, ano em que se encerrou o governo do último presidente paulista de nascimento, as que diziam respeito à história local (mais do estado do que propriamente da cidade) avançaram até a década de 1930, demarcando escolhas bastante significativas. Segundo o texto introdutório do catálogo, a "autonomia administrativa, decorrente da nova estrutura política do país" teria favorecido o desenvolvimento econômico paulista: o federalismo era assim vivamente celebrado como a razão do sucesso econômico e da possibilidade de o estado desfrutar de suas glórias. Seguiam-se os números que atestavam o crescimento da cafeicultura, o lançamento das bases da policultura, bem como o enriquecimento do parque industrial. Tal crescimento econômico era acompanhado pelo crescimento demográfico.

Um mural da pintora Estrela de Faria representava o movimento imigratório e outro de Arnaldo Pedroso d'Horta simbolizava o progresso industrial do estado. Gravuras e documentos tratavam dos assuntos do café e da rede ferroviária, mencionando inclusive o Convênio de Taubaté, que em 1906 firmou entre Minas Gerais, Rio de Janeiro e São Paulo uma política de defesa do produto. Alberto Santos Dumont e suas experiências sobre o avião foram apresentados em um painel, abrindo o caminho para a exposição das atividades de cientistas e educadores paulistas. Intelectuais e artistas como Amadeu Amaral, Vicente de Carvalho, Ramos de Azevedo e Monteiro Lobato figuravam no painel que apresentava o panorama das letras e das artes no período, encerrados por outro dedicado à educação em todos os níveis e aos modernos e suas obras: Paulo Prado e Paulística, Alcântara Machado e Laranja da China, Mário de Andrade e Losango Cáqui. A legenda de abertura do segmento mencionava a Semana de Arte Moderna de 1922 como de grande alcance na renovação artística e literária do Brasil.

Caminhando para o fim do percurso da exposição, as transformações da capital paulista foram expostas por meio de fotografias ampliadas de lugares que não mais existiam ou por outros que foram totalmente transfigurados. Nesse aspecto, apresentava-se uma série de mapas levantados especialmente para a exposição, "mostrando com todo o rigor científico a marcha da urbanização da capital paulista" de século em século, de 1554 a 1954. Antigas sesmarias tornaram-se sítios e chácaras, por fim transformados em lotes, ruas, praças públicas.

Antes desta série, entretanto, dois painéis e uma vitrine foram dedicados ao episódio então recente da chamada Revolução Constitucionalista de 1932. A legenda que comunicava o evento que havia mobilizado corações e mentes 
paulistas, enquadrava o acontecimento à narrativa ora apresentada da "história de São Paulo no quadro da história do Brasil". $\bigcirc$ texto mencionava "três ciclos de conquistas": o da terra, o do ouro e o que dava "legitimidade ao chão, que desbravaram as bandeiras e as monções [...], que engendraram as minerações e as lavras, o da conquista da lei", representado pela "Guerra Cívica do 9 de julho de 1932", ciclo que embora breve no tempo era "longo no sentido". Aludindo a uma fusão dos paulistas "num único ser humano" acima de todas as diferenças, a exposição também fundia nos objetos - como a bandeira paulista hasteada pelos estudantes de Direito na Academia em 1932, pertencente a Júlio de Mesquita Filho, armas, distintivos, fotografias e um mapa das frentes de combate pertencente ao poeta, presidente da CIVCCSP e ex-combatente Guilherme de Almeida ${ }^{62}$ - o sentido de toda a exposição. Sobre Getúlio Vargas, cujo suicídio ocorrera semanas antes da abertura da exposição, o absoluto silêncio.

último painel da exposição comunicava, por meio de um texto-síntese, o sentido da mostra que ali se encerrava. Ao visitante, o corolário da didática - como se apresentava na imprensa local - a apresentação da história de São Paulo no quadro da história do Brasil:

\begin{abstract}
Com a herança das culturas europeias transplantadas pela audácia dos navegantes portugueses para as terras da América; com o conhecimento dos caminhos e das coisas da terra ensinados pelos índios; com o espírito do cristianismo trazido pelos apóstolos e os missionários; com a tenacidade e a bravura dos bandeirantes descobrindo e povoando territórios; com o humilde e formidável trabalho dos negros e mestiços, com o sentimento de nativismo e os impulsos patrióticos que levaram à Independência do Brasil; com o esforço dos soldados nos campos de batalha; com a experiências dos imigrantes nas labutas do campo e da cidade construiu-se a grandeza de São Paulo. ${ }^{63}$
\end{abstract}

Como se fossem créditos, qualificando a forma como cada grupo social teria contribuído para a grandeza de São Paulo, o painel final parecia dessa forma querer causar no visitante - especialmente se ele fosse paulista e representasse de alguma forma a herança de algum dos grupos sociais mencionados - o sentimento de pertença aos signos de identidade que ali se expunham materialmente: a exposição era assim um patrimônio, e a cada qual cabia o seu quinhão. Além disso, as frases gravadas no painel sintetizavam ideias presentes em cada uma das seções, elegendo os que haviam tornado possível aquela narrativa, não indicando, porém, alternativas para caracterizar o percurso.
62. O escritor substituiu Matarazzo na presidência da CIVCCSP depois de desentendimentos entre este e a administração municipal.

63. Com pequenas diferenças que não alteram o sentido, o texto foi transcrito tanto na introdução do catálogo quanto na descrição pormenorizada da exposição. O painel que encerrava a seção e a exposição era o $135^{\circ}$. 
64. Miguel Paile foi quem transcreveu e remeteu a programação e o convite para Cortesão do Congresso Internacional de História que seria realizado em São Paulo, organizado pelos professores da Universidade de São Paulo. O evento não aconteceu.

65. O Estado de S. Paulo, São Paulo, 14 set. 1954 , p. 12.

\section{NO QUADRO DA HISTÓRIA DE PORTUGAL, UMA EXPOSIÇÃO DIDÁTICA, CÍVICA E CIENTÍFICA}

A fita de abertura da exposição foi cortada pelo Ministro português dos Negócios Estrangeiros Paulo Cunha, que estava no país em visita oficial, ocorrida tempos depois de ter sido celebrado em Lisboa, com a presença de representantes do poder executivo da cidade e do estado de São Paulo, o transcurso do quarto centenário paulistano. Na ocasião, estiveram ainda presentes o embaixador de Portugal no Brasil, Miguel Paile, ${ }^{64}$ além de Júlio de Mesquita Filho, Francisco Matarazzo Sobrinho e os membros do Segundo Colóquio de Estudos LusoBrasileiros, entre tantos outros convidados. De maneira "inédita e moderna", os quatro séculos de história paulista - e de história do Brasil - eram contados, conforme registrava no dia seguinte o matutino de Mesquita Filho.

No discurso de Jaime Cortesão não faltaram homenagens ao ex-presidente da Comissão, Matarazzo, a quem atribuiu o mérito da iniciativa de realizar uma exposição de história, bem como tomar a decisão "muito arriscada" de convidá-lo para executála. A Guilherme de Almeida agradeceu o mesmo estímulo, bem como aos governos estrangeiros que se dispuseram a contribuir com a cedência de documentos e obras. Deferência maior coube ao governo português, a quem se deveu a exposição de obras e importantes documentos "referentes ao mais remoto passado da história brasileira". Além disso, Cortesão agradeceu aos colaboradores, artistas e técnicos, mencionando especialmente os nomes dos que planejaram o roteiro e a montagem da exposição: Mário Neme, Ernani Silva Bruno, Manuel Lapa.

A preocupação máxima dos organizadores da mostra, segundo Jaime Cortesão, teria sido a "ordenação lógica e científica", sem descuidar "da documentação histórica nem da distribuição das várias seções, que vão desde a época do descobrimento aos nossos dias". A edição d'O Estado de S. Paulo da data em que a exposição seria aberta ao público, no fim da tarde, registrava um trecho da fala de Cortesão que metaforizava a exposição em uma viagem marítima: "Chegados que fordes à $1^{a}$ seção, tantas são as evocações marítimas, que vos surpreendereis, como se estivésseis a bordo. Oxalá a viagem não vos fatigue e seja grata. E permiti, agora, que eu me arvore em piloto de largada". 65

Dois meses após a abertura, uma reportagem no mesmo periódico que acompanhou todo o desenvolvimento da exposição comentava o "vivo interesse" que a mostra vinha despertando no público. Em um edifício de "ousada arquitetura", a exibição que ocupava os dois pisos do pavilhão era marcada por seu ineditismo no país: não se tratava de uma simples exposição de objetos - era "um certame, 
por assim dizer, vivo, em que se casam arte e história para oferecer uma visão de conjunto dos quatro séculos e vida de São Paulo e de seu papel na história pátria". A reportagem, em tom de divulgação, a identificava como "ao mesmo tempo didática e científica", estando ao alcance tanto do "grande público" quanto dos "estudiosos, que ali encontram material valiosíssimo, muitas vezes inédito, que desvenda curiosas perspectivas no campo da historiografia". $\bigcirc$ didatismo residia no fato da exposição proporcionar aos estudantes "uma proveitosa lição de história pátria". Infelizmente não assinada, a resenha publicada no jornal para o qual Cortesão e diversos outros intelectuais de sua rede escreviam, citava ainda que milhares de pessoas acorriam ao Palácio de Exposições diariamente, não escondendo seu entusiasmo. Ademais, o circuito "cultural e cívico" exposto dispunha de monitores "cuidadosamente selecionados". 60

Outro dado da recepção da exposição pode ser encontrado na seção "Colaboração dos Leitores" do mesmo jornal. Nela foi publicada a carta do Sr. Francisco Machado de Campos, intitulada Uma falha da exposição do Centenário. - leitor começava por destacar a grandiosidade do Ibirapuera, de seu ponto de vista pensado para uma cidade bem maior do que a que existia, e para a realização de "futuras e exuberantes mostras de nosso desenvolvimento econômico e cultural". Campos, que se autodenomina "turista na história", comparou o que leu no Guia para o visitante e o que viu exposto: se no folheto indicavam uma homenagem "aos homens que construíram a grandeza de nossa Pátria", da mostra chamou a atenção a menção "desde o Infante D. Henrique, até Fernando Lemos, autor do painel decorativo do hall da Exposição" (Figura 18), grande parte deles portugueses. $\bigcirc$ leitor assinalou também que apesar de todas as menções ao desenvolvimento científico e educacional, a exposição havia falhado ao não registrar "a criação de nosso instituto máximo de cultura que é a Universidade de São Paulo, a matriz das universidades brasileiras, concebida pelo estadista de escol que foi Armando de Salles Oliveira". ${ }^{67}$

A redação do jornal registrou sua concordância no essencial com o leitor, apontando para o fato da própria folha não ter poupado elogios à realização da exposição e de ter discordado de seu local de realização, reafirmando sua posição contrária à construção dos pavilhões no Parque lbirapuera. ${ }^{68}$ Do ponto de vista da redação, a crítica de Campos foi feliz, reiterando que a criação da Universidade era "um dos acontecimentos de maior relevo da nossa história, marcando o início de uma nova fase da evolução paulista". Complementando o que o missivista disse, a redação do matutino afirmou que diversos acontecimentos e personalidades que "de modo algum deviam figurar num certame daquela envergadura" foram acentuados em detrimento do silêncio que pairou sobre Armando de Salles Oliveira
66. O texto traz a informação sobre o funcionamento da exposição, aberta ao público da terça-feira ao sábado das $14 \mathrm{~h} 30$ às $22 \mathrm{~h} 30$ $\mathrm{e}$ aos domingos das $12 \mathrm{~h}$ às 22h30. O Estado de $S$. Paulo, São Paulo, 30 nov. 1954, p. 9.

67. O Estado de S. Paulo, São Paulo, 5 dez. 1954, p. 6.

68. A esse respeito, cf. Barone (2009). 
69. O Estado de S. Paulo, São Paulo, 5 dez. 1954, p. 6.

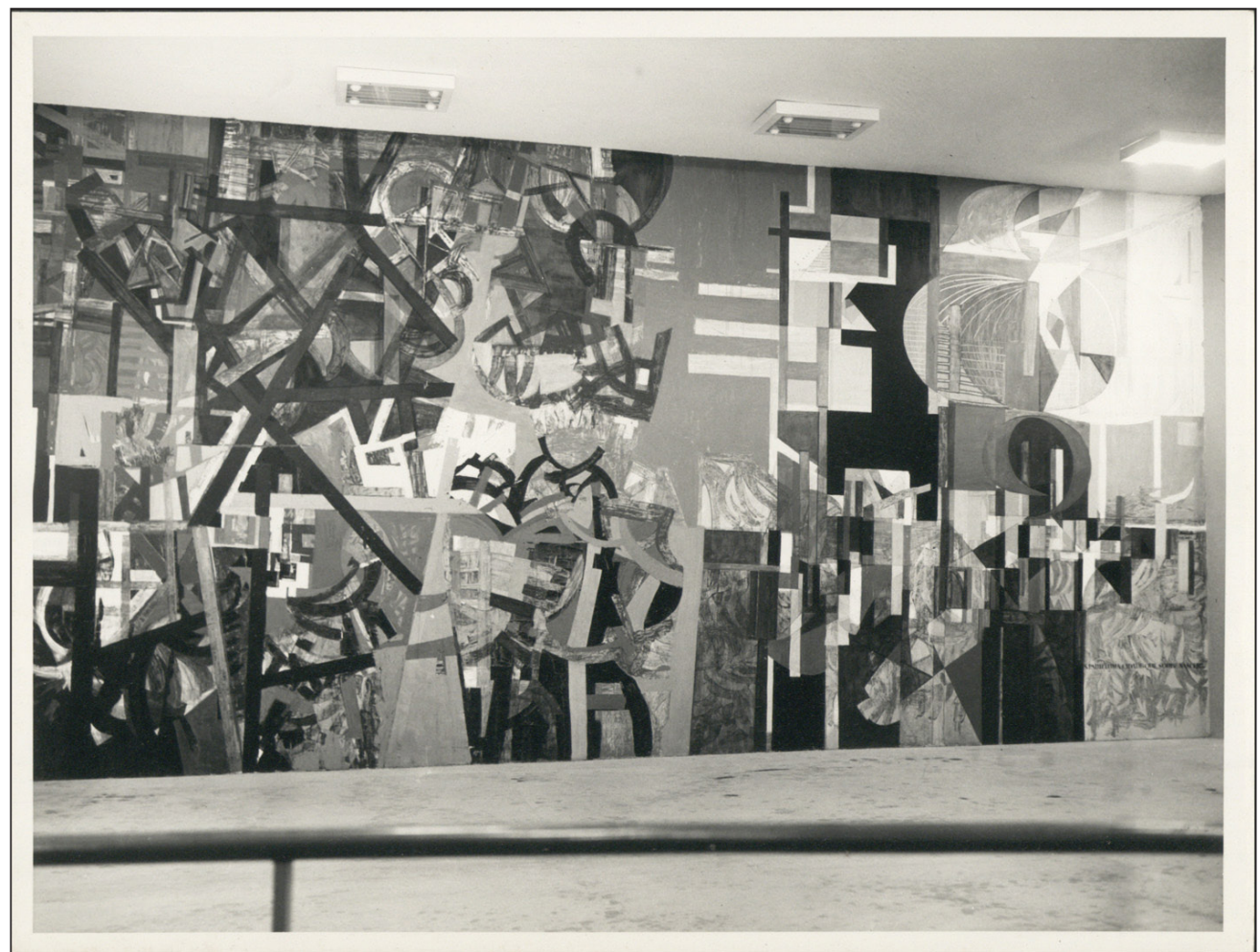

Figura 18 - Mural de Fernando Lemos evocando o esforço criador de São Paulo. São Paulo, s/d. Fonte: BNP/ACPC, E25/1511. Foto: Fotógrafo não identificado.

e a Universidade, iniciativa que, segundo a redação, ampliava as perspectivas políticas e econômicas do estado. ${ }^{69}$ Tal crítica se dirigia mais sobre os organizadores das últimas seções do que sobre Cortesão. Entretanto, por mais que Campos não escrevesse literalmente, de suas menções ao Infante D. Henrique a Fernando Lemos, pode-se subentender o excesso de relevo às personalidades portuguesas na exposição, que apresentaria aqueles que fizeram a grandeza de São Paulo e que naturalmente, de acordo com seu raciocínio, deveriam ser paulistas. Vale lembrar que os organizadores das últimas seções eram vindos dos círculos tradicionais da produção do conhecimento histórico local, como a Academia de Direito e o HGGSP.

Em março de 1955, quando a exposição se encerraria, uma série de textos assinada por Cortesão apresentou aos leitores o Plano geral, suas seções / da primeira à sextal e o Balanço final da mostra. $\bigcirc$ primeiro dos textos citava, de largada, os "louvores da imprensa, de entidades científicas e de particulares", que não tiveram reservas em congratular a organização da exposição. Isso servia para se contrapor às "vozes discordantes", que eram postas em segundo plano diante de instituições "da mais alta categoria" como a Academia Brasileira de Letras, o 
$\| H G B$ e o $\|$ GSSP. Situando-as em dois polos opostos, Cortesão condensou as críticas em torno de dois exemplos: o de um historiador que protestou contra as figurações decorativas, defendendo uma apresentação limitada ao aspecto científico; e outros que entenderam que à exposição faltavam quadros "genuinamente paulistas", especialmente em comparação à "parte portuguesa" ${ }^{70}$

Diante de tais críticas, Cortesão registrou na coluna que não esperava unanimidade, considerando que "divergências fundamentais" se digladiavam sobre a própria interpretação da história. De seu ponto de vista, entretanto, teriam sido injustas as acusações de ter se ocupado "com particular carinho" da "parte portuguesa" em relação à paulista. Em desagravo, o desmentido às insinuações seria a preparação e o lançamento de A fundação de São Paulo: capital geográfica do Brasil. Na obra, à luz de novos documentos e "novos métodos de interpretação", resolvia-se o problema da fundação. Produzido nas horas de descanso do processo de organização da exposição, o livro seria sua "contribuição pessoal às comemorações paulistas". $\bigcirc$ autor mencionou ainda as publicações em curso de Alexandre de Gusmão e o Tratado de Madrid e os quarto e quinto volumes da Coleção De Angelis, além da Pauliceae Lusitana Monumenta Historica, que trariam consigo uma infinidade de documentos fundamentais para a historiografia paulista, que seriam, em suas palavras, os escudos a prołegê-lo da "injúria", lembrando de todos os percalços para a execução de um trabalho tão vultoso com recursos limitados e em um curto intervalo de tempo. ${ }^{71}$

$\bigcirc$ autor ainda lembrava aos leitores - especialmente a seus críticos - que se tratava de uma exposição de acordo com os "conceitos contemporâneos da História, muito avessos da narrativa anedótica e episódica", lembrando para tanto - papel dos "ilustres escritores e historiadores paulistas" Mário Neme, Hélio Damante e Ernani Silva Bruno, autor da "mais notável das obras sobre a história de São Paulo", citando História e tradições da cidade de São Paulo, publicada sob o selo oficial da Comissão organizadora dos festejos. Sobrelevando os mapas, Cortesão reiterou o ineditismo do que foi exposto, mencionando a intenção de publicar o catálogo, capaz de dar a dimensão da realização. ${ }^{72}$

No Balanço final, o autor comentou sobre outras críticas, como a que portava sobre a ausência de uma dita profecia de Anchieta: de caráter "lógico" e "científico", não cabia à exposição tratar de assunto sobre o qual não haveria documentos. Considerando as seções finais, Cortesão reiterou o elogio a Neme e a Bruno, bem como a Damante, ressaltando o painel final em que se davam os créditos aos que haviam contribuído para a formação paulista. $\bigcirc$ autor encerrou seu texto relembrando os esforços necessários à execução da exposição, montada em quatro meses e abrindo mão de diversos documentos por falta de espaço. Do
70. Jaime Cortesão, em $O$ Estado de S. Paulo, São Paulo, 13 mar. 1955, p. 9.

71. Jaime Cortesão, em $O$ Estado de S. Paulo, São Paulo, 13 mar. 1955, p. 9.

72. Jaime Cortesão, em $O$ Estado de S. Paulo, São Paulo, 13 mar. 1955, p. 9. 
73. Jaime Cortesão, em $O$ Estado de S. Paulo, 3 abr. 1955 , p. 7. De fato, a exposição foi remodelada em novembro de 1955 , quando foram devolvidas peças pertencentes a outros estados. Em julho de 1956 foi reaberta, sem alteração do plano original de seções. Em nota n'O Estado de S. Paulo (9 jan. 1957, p. 10), é possível identificar que a exposição era aberta aos sábados, domingos e feriados, contando com réplicas dos originais já devolvidos. crítico literário Valdemar Cavalcanti, Cortesão cita seus elogios à execução da mostra, conclamando para que ela se tornasse permanente, mesmo que sem algumas de suas peças, cedidas por outras instituições: seria inconcebível que "uma obra de tamanho significado e alcance fosse de uma hora para outra fechada e dissolvida, como se se tratasse de uma simples barraca de um parque de diversões". ${ }^{73}$ Mais do que uma exposição, poderia se tornar um museu.

Além dos títulos citados por Cortesão como demonstrativos de sua preocupação com a historiografia paulisła, trazendo à discussão não apenas novos documentos como também novas interpretações sobre a fundação e a colonização da região vicentina, estiveram vivamente presentes no percurso montado na Oca ideias e conceitos escritos em suas obras de história, desde A expedição de Pedro Álvares Cabral e o descobrimento do Brasil (1922) à História do Brasil nos velhos mapas (1965/1971), que seria lançada postumamente. Além disso, da terceira à sexła seção condensaram-se as elaborações presentes em A fundação de São Paulo, capital geográfica do Brasil (1955) e no posterior Raposo Tavares e a formação territorial do Brasil (1958), bem como em Alexandre de Gusmão e o Tratado de Madri (1949 em diante) e nos documentos dos Angelis. Ao visitante que não conhecesse os trabalhos do autor, no entanto, as referências talvez se restringissem aos exemplares de Alexandre de Gusmão dispostos na sexta seção.

Ressaltada pelos seus caráteres cívico, didático e científico, a exposição demonstrou, a despeito da mencionada convergência entre Cortesão e seus colaboradores diretos, uma diferença entre o primeiro bloco, da primeira à sexta seção e o segundo, da sétima à nona. Se no primeiro bloco predominou a perspectiva de produção histórica de Cortesão, marcada substancialmente pela cartografia como fonte privilegiada, dividindo espaço com as artes visuais - ainda que a própria cartografia se aproxime dessa categoria -, no segundo bloco houve um predomínio de uma narrativa baseada na história político-administrativa. Embora perpassando assuntos do cotidiano, o segundo bloco pendia mais para o cívico do que para o científico do primeiro, ainda que se reconheçam elementos semelhantes no conjunto da exposição.

Tomando a obra A fundação de São Paulo de Cortesão como referência de sua apreensão do sentido da exposição, e baseando-se também em suas respostas às críticas e a constante reiteração de que se tratava de uma exposição sobre São Paulo, mas inserida no quadro do processo histórico brasileiro, é possível afirmar que a mostra apresentada no Palácio de Exposições tinha por objetivo maior mostrar - a partir da utilização de mapas "inéditos" - a forma pela qual São Paulo havia construído o Brasil. E não apenas territorialmente. E não somente no passado das bandeiras ou das monções. Lembremos da infinidade de símbolos 
com os quais as pessoas eram bombardeadas diuturnamente, certamente contribuindo de forma decisiva para a forma como a narrativa construída por Cortesão e seus colaboradores era apreendida.

Retomando uma fala de Cortesão de 1940, sua primeira no Brasil na sede d'A Gazeta em São Paulo, podemos compreender em parte o olhar que o historiador lançava sobre a "metrópole dos bandeirantes", espécie de "reencarnação do espírito lusíada dos Descobrimentos, coração do sertanismo épico, cujas pulsações golfaram sobre o imenso território [...] o sangue luso-brasileiro, que unificou a Pátria Nova, na mesma circulação titânica". Lançando as bases da tese que acompanharia seu percurso historiográfico brasileiro, Cortesão tornava o bandeirismo a "maior glória portuguesa", que antes de qualquer outro povo colonizador teria sido capaz de criar uma raça e uma cultura euroamericana. Difundindo-se a partir do planalto paulista, essa criação portuguesa seria o foco da "mais vasta e continuada difusão de cultura europeia, que jamais povo algum criou em mundos novos". A tal "glória portuguesa" ou "expressão heroica tão lusitana como brasileira" acompanharia o historiador em sua jornada de quase duas décadas de trabalho no Brasil. ${ }^{74}$ Seu olhar para a Pauliceia le para o fenômeno das bandeiras), no entanto, se cruzaria com outros tantos: o dos tempos do Estado Novo brasileiro; o dos modernistas; o da historiografia paulista; o do conhecimento geográfico em autonomização; o das elites paulistas; o da intelectualidade. Na exposição - inserida no amplo contexto que a engendrou encontramos, enfim, uma interessante convergência de todos eles.

\section{CONCLUSÕES, OU JAIME CORTESÃO COMO MUSEÓLOGO}

Alguns vestígios permitem perceber a forma como a linguagem dos museus teria acompanhado Cortesão após o encerramento de seus trabalhos junto à Comissão do IV Centenário. Em um texto escrito em abril de 1956, quando passava uma temporada em Estoril, Cortesão delineou o que seria o Museu dos Descobrimentos, a ser instalado na capital portuguesa: o espaço havia sido previsto pelo governo português, que abriu um concurso em 1954 para selecionar o projeto que seria executado. $\bigcirc$ texto consta de uma correspondência enviada aos arquitetos Carlos e Guilherme Rebelo de Andrade, que tinham convidado Cortesão para ser o consultor nos assuntos de história, além de planejador/executor do que seria o museu. Recebendo pelo trabalho, o historiador pedia "a superior direção e liberdade na execução", mencionando como colaboradores Leitão de Barros,
74. Cf. Jaime Cortesão (BNP/ACPC, E25/40, dez. 1940). 
Álvaro de Brée, Martins Barata e um de seus principais colaboradores na exposição paulista, representando o modernismo português, Manuel Lapa.

As seis seções de Cortesão para a mostra paulistana aparecem sob os mesmos títulos e lançando mão essencialmente dos mesmos objetos e recursos no plano do Museu dos Descobrimentos. Na descrição da primeira seção, Cortesão informava aos arquitetos que aproveitaria naquela o material cartográfico preparado para a exposição de São Paulo. Entretanto, ao seguir a leitura do plano das seções seguintes, não eram apenas os materiais cartográficos da exposição de 1954 que seriam aproveitados: o que tinha servido para narrar o papel paulista na formação do Brasil serviria também compor o museu destinado a narrar os Descobrimentos. Ainda que o plano não tenha logrado êxito - nem o de Cortesão e dos arquitetos, nem o de um museu dedicado às descobertas - não foi possível identificar se e nem quais outros elementos seriam adicionados ao plano então apresentado. De qualquer modo, ratificava-se o enquadramento das histórias paulista e brasileira na história de Portugal, baseando uma nova narrativa museológica no pouco ou nada modificado plano de Cortesão executado no Ibirapuera.

Em 1958, reunido no conjunto documental "Cartas de Portugal" encontra-se um texto intitulado "Introdução histórica aos museus de arte portugueses", levando também a inferir quais poderiam ter sido os caminhos de Cortesão após seu retorno a Portugal. No escrito, o autor "um quarto de século" fora do país comentou o crescimento do número de museus de arte, instituições que segundo o historiador poderiam renovar e enriquecer a "consciência de nação", além de melhorar o interesse, o gosto e a cultura artística do público. Ademais, Jaime Cortesão disse do incremento das visitações às exposições e do desejo no país de perpetuar e renovar sua história a partir de uma valorização de seu passado de "grande pátria". Para tanto, lembrou o papel do ex-presidente Antônio José de Almeida (1919-1923), antes de quem nenhum outro governante português teria se empenhado no setor da educação. Foi nesse mandato que Cortesão dirigiu a Biblioteca Nacional de Portugal.

Cortesão mencionou o trabalho de José de Figueiredo - ao lado de quem iá havia atuado - e do Museu Nacional de Arte Antiga. De acordo com o historiador, Figueiredo havia revolucionado a forma de dispor as obras de arte em salas, sendo assim um "dos grandes renovadores da museologia", adotando práticas antes delas serem largamente adotadas em muitos museus estrangeiros. Tais práticas consistiriam na exposição de obras-primas em espaços amplos, para que não houvesse prejuízo entre elas, além do recurso da harmonização entre ambiente e obras: colocava-se fim ao museu-armazém. Para dar suporte a suas afirmações sobre Figueiredo, Cortesão mencionou a revista Muséographie, que 
destacou o trabalho do português e o recomendou, tendo sido então adotado pelos museus do Louvre, do Prado e o Nacional de Florença. ${ }^{75}$

Seguindo pela vereda aberta por essas fontes - ambas posteriores à experiência brasileira e aos intensos trabalhos em torno da exposição paulista de 1954 - pode-se notar tanto certo interesse pela temática dos museus como também a forma como Cortesão percebia esses espaços. Ao que sugerem tais textos, o historiador tinha expectativas em razão do aumento do interesse do público pelos museus, o que demonstraria um desejo dessa população de renovar a história de Portugal: duas informações que apresentariam um fértil terreno a explorar, lançando nele as sementes que Cortesão havia descoberto ou amadurecido no Brasil. No exílio, além de descobrir a história nos arquivos e mapas, percebia que museus e exposições também poderiam ser um caminho muito proveitoso para animar a "consciência de nação". Era mais uma peça em seu projeto de fazer renascer Portugal.

Tathianni Silva, em trabalho sobre o intelectual Mário Neme, um dos colaboradores mais atuantes de Cortesão na exposição paulistana, indica um interessante percurso de análise para as consequências daquele trabalho realizado pelo grupo liderado pelo historiador português. ${ }^{76}$ Neme, logo após as atividades na exposição, foi indicado para dirigir a Casa do Bandeirante lespaço museológico na região do Butantã, na capital paulista) e em 1960 assumiu a direção do Museu Paulista. Neste museu, promoveu sua incorporação à Universidade de São Paulo, tencionando criar uma instituição ao mesmo tempo pedagógica e científica. Com as diversas mudanças que empreendeu de acordo com a visão da nova museologia, o intelectual buscou transformar o espaço em "um museu de conceito contemporâneo sobre a história do Brasil, com ênfase no período colonial". Silva ainda menciona que, "enquanto um intelectual modernista que acreditava na educação como mediadora de conflitos sociais", Neme imprimia sua marca e construía em torno de si "um grande leque de possibilidades e contatos que the favoreceram intensamente durante sua gestão à frente do museu". 77

As visitas que Mário Neme havia feito a Portugal e os diálogos realizados por meio da nova museologia de João Couto, que tinham transformado "a maneira de se trabalhar e pensar os espaços museológicos", tiveram bastante influência sobre o trabalho do intelectual à frente do Museu Paulista. Couto, na direção do Museu Nacional de Arte Antiga, procurando "inserir Portugal com seus museus no circuito de visitações e discussões acerca do assunto no contexto europeu", deu importância à educação, à conservação e ao restauro, à produção científica e à formação de profissionais, iniciativas que também foram marcantes da gestão de Neme. Participando ativamente do delineamento de uma futura política para os
75. Cf. Jaime Cortesão (BNP/ACPC, E24/35, 1958).

76. Cf. Silva (2014).

77. Silva (2014, p. 85, 9697). Registre-se ainda que, segundo a autora, Neme fazia parte das revistas Clima e Planalto e era um importante elo entre os intelectuais da Universidade - os "moços" da Clima - e os intelectuais "da cidade". Além disso, cabe ressaltar que antes de Neme o Museu Paulista havia sido dirigido por Afonso Taunay entre 1917 e 1945; Sérgio Buarque de Holanda e Herbert Baldus (especialmente na área de etnografia) entre 1946 e 1956; Herbert Baldus entre 1957 e 1959. Neme chegou à direção do Museu Paulista por intermédio de Paulo Duarte. 
78. Silva (2014, p. 170-171, 192).

79. Ernani Silva Bruno foi o primeiro diretor do atual Museu da Casa Brasileira, criado no início da década de 1970 em São Paulo como Museu do Mobiliário Artístico e Histórico Brasileiro, funcionando desde 1972 em um solar neoclássico que foi residência do ex-prefeito Fábio Prado.

80. Cortesão (1955, p. 17). museus brasileiros, o intelectual mobilizou sua experiência na organização da exposição do quarto centenário paulistano, na Junta Coordenadora dos Museus Municipais de São Paulo e por fim no Museu Paulista. ${ }^{78}$ Desse modo, tanto em Neme quanto em Cortesão - e também em Ernani Silva Bruno, que esteve à frente do Museu da Casa Brasileira, em São Paulo ${ }^{79}$ - são identificáveis algumas das sementes lançadas a partir da organização da exposição de 1954 somente no campo da museologia.

A despeito de ter qualificado sua contribuição às comemorações do quarto centenário de São Paulo como altamente cuidadosas no trato dos assuntos da história paulista e de suas figuras, eventos e documentos mais relevantes, inseridos em um dos marcos de sua arquitetura e pautados pela originalidade e pelo ineditismo, Jaime Cortesão, auxiliado decisivamente pelos portugueses radicados no Brasil e pelo governo de seu país - apesar de ter sido banido pelo mesmo governo há menos de duas décadas - inseriu a organização da exposição no quadro dos feitos de Portugal no mundo. De seu ponto de vista, e em resposta aos que the disseram demasiadamente cuidadoso das coisas de Portugal, as categorias de cidadão brasileiro e português se fundiriam numa única: "uma das melhores formas de ser português" seria "amar e servir o Brasil". ${ }^{80}$ Entretanto, no quadro de sua trajetória e da circulação de ideias relacionadas à história da colonização portuguesa no mundo, valorizando sobretudo a plasticidade, a adaptação aos povos naturais das regiões colonizadas e visibilizando uma "comunidade de cultura" entre os povos de língua oficial portuguesa, o sentido da declaração de Cortesão não é meramente uma frase-feita. 


\section{REFERENCIAS}

ALENCASTRO, Luiz Felipe de. O trato dos viventes: formação do Brasil no Atlântico Sul. São Paulo: Companhia das Letras, 2000.

ALEXANDRE, Valentim. Velho Brasil, novas Áfricas: Portugal e o Império (1808-1975). Porto: Afrontamento, 2000.

BARBUY, Heloisa. A exposição universal de 1889 em Paris. São Paulo: Loyola, 1999. . A cidade-exposição: comércio e cosmopolitismo em São Paulo, 1860-1914. São Paulo: Edusp, 2006.

BARONE, Ana Cláudia Castilho. A oposição aos pavilhões do Parque Ibirapuera (1950-1954). Anais do Museu Paulista, São Paulo, v. 17, n. 2, p. 295-316, jul./dez. 2009.

BRUNO, Ernani Silva. História e tradições da cidade de São Paulo. 2. ed. Rio de Janeiro: José Olympio, 1954. $3 \mathrm{v}$.

CASTELO, Claudia. O modo português de estar no mundo: o luso-tropicalismo e a ideologia colonial portuguesa (1933-1961). Porto: Afrontamento, 1998.

CORTESÃO, Jaime. A fundação de São Paulo: capital geográfica do Brasil. Rio de Janeiro: Livros de Portugal, 1955.

13 cartas do cativeiro e do exílio (1940). Lisboa: Biblioteca Nacional, 1987.

FERREIRA, Antonio Celso. A epopeia bandeirante: letrados, instituições, invenção histórica (1870-1940). São Paulo: Editora Unesp, 2002.

KANTOR, Íris. Usos diplomáticos da ilha-Brasil: polêmicas cartográficas e historiográficas. Varia Historia, Belo Horizonte, v. 23, n. 37, p. 70-80, jan./jun. 2007.

. Cartografia e diplomacia: usos geopolíticos da informação toponímica (1750-1850). Anais do Museu Paulista, São Paulo, v. 17, n. 2, p. 39-61, jul./dez. 2009.

LEMOS, Fernando; LEITE, Rui Moreira (Org.). A missão portuguesa: rotas entrecruzadas. Bauru: Edusc; São Paulo: Editora Unesp, 2003. 
LOFEGO, Silvio Luiz. IV Centenário da Cidade de São Paulo: uma cidade entre o passado e o futuro. São Paulo: Annablume, 2004.

MACEDO, Jorge Borges de. A teoria da história de Jaime Cortesão. Prelo, Lisboa, p. 57-66, dez. 1984. Suplemento.

MARINS, Paulo César Garcez. O Parque do Ibirapuera e a construção da identidade paulista. Anais do Museu Paulista, São Paulo, v. 6, n. 1, p. 9-36, 1999.

MARTINS, José de Souza. A São Paulo de German Lorca. São Paulo: Imprensa Oficial; Secretaria Municipal de Cultura, 2013.

MONTEIRO, John Manuel. Tupis, Tapuias e historiadores: estudos de história indígena e do indigenismo. 2001. 233 f. Tese (Livre-docência em Etnologia) - Instituto de Filosofia e Ciências Humanas, Universidade Estadual de Campinas, Campinas, 2001.

OLIVEIRA JÚNIOR, Gilson Brandão. Agostinho da Silva e o Centro de Estudos Afro-Orientais (CEAO): a primeira experiência institucional de estudos africanos no Brasil. 2010. $235 \mathrm{f}$. Dissertação (Mestrado em História) - Faculdade de Filosofia, Letras e Ciências Humanas, Universidade de São Paulo, São Paulo, 2010.

PINHO, Amon. A diáspora da inteligência lusa na hermenêutica histórica de Agostinho da Silva: uma teoria antielitista da história de Portugal? Convergência Lusíada, Rio de Janeiro, v. 23, p. 28-44, 2007. Suplemento.

PONTES, Heloisa Andre. Destinos mistos: os críticos do grupo Clima em São Paulo (1940-1968). São Paulo: Companhia das Letras, 1998.

RIBEIRO, Aquilino. Reencontro com Jaime Cortesão. Seara Nova. Lisboa, n. 1266-1269, p. 187-189, dez. 1952.

RIBEIRO, David William Aparecido. "São Paulo, capital geográfica do Brasil": a Exposição do IV Centenário de São Paulo e a formação do território brasileiro na escrita histórica de Jaime Cortesão (1940-1960). São Paulo: Intermeios; Fapesp, 2018.

SANTOS, Alfredo Ribeiro dos. Jaime Cortesão: um dos grandes de Portugal. Porto: Fundação Engenheiro Antonio de Almeida, 1993.

SCHWARCZ, Lília. O espetáculo das raças: cientistas, instituições e questão racial no Brasil, 1870-1930. São Paulo: Companhia das Letras, 1993. 
SECCO, Lincoln. A Revolução dos Cravos. São Paulo: Alameda, 2004.

SILVA, Tathianni Christinni da. Um intelectual caipira na cidade: a trajetória de Mário Neme e a sua gestão no Museu Paulista. 2014. 389 f. Tese (Doutorado em História) - Faculdade de Filosofia, Letras e Ciências Humanas, Universidade de São Paulo, São Paulo, 2014.

THOMAZ, Omar Ribeiro. Ecos do Atlântico Sul: representações sobre o terceiro império português. Rio de Janeiro: Editora UFRJ; São Paulo: Fapesp, 2002.

Artigo apresentado em 01/08/2017. Aprovado em 05/02/2018

\section{(cc) BY}

All the contents of this journal, except where otherwise noted, is licensed under a Creative Commons Attribution License 